RUNOFF AND WATER-QUALITY CHARACTERISTICS OF SURFACE-MINED LANDS IN ILLINOIS

By Timothy P. Brabets

U.S. GEOLOGICAL SURVEY

Water-Resources Investigations Report 83-4265

Prepared in cooperation with the

U.S ENVIRONMENTAL PROTECTION AGENCY

Urbana, Illinois 


\section{UNITED STATES DEPARTMENT OF THE INTERIOR \\ WILIIAM P. CLARK, Secretary}

GEOLOGICAL SURVEY

Dallas L. Peck, Director

For additional information, write to:

District Chief

U.S. Geological survey

water Resources Division

4th Floor

102 East Main street

Urbana, II 61801
Copies of this report can be purchased from:

Open-File services section Western Distribution Branch U.S. Geological survey Box 25425, Federal Center Denver, Co 80225

[Telephone: (303) 234-5888] 


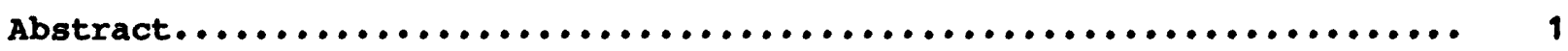

1.0 Introduction. ........................................

1.1 Coal reserves in Illinois................................

1.2 Geologic formations................................. 4

1.3 History and laws...................................

1.4 Problem and purpose................................. 8

2.0 Areas of study.............................................

2.1 Western Illinois................................... 9

2.2 southwestern Illinols.................................11

2.3 Southern Illinois.....................................13

3.0 surface water.......................................... 16

3.1 streamflow characteristics............................. 16

3.2 Precipitation and runoff............................ 18

3.3 storm runoff........................................ 21

3.4 Flow duration and variability......................... 25

3.5 Synthetic flow-duration curves......................... 30

3.6 Conclusions........................................ 35

4.0 quality of surface water................................. 36

4.1 Water-quality characteristics......................... 36

4.2 Specific conductance as indicator of dissolved sol1ds........ 38

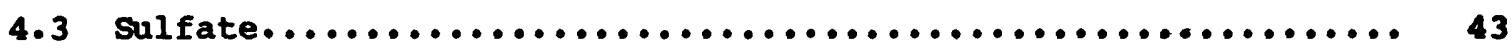

4.4 Calcium........................................... 47

4.5 Water temperature................................... 51

4.6 suspended sediment................................... 55

4.7 Aluminum.............................................59

4.8 Iron. ...............................................62

4.9 Manganese and zinc..................................65

4.10 Trace elements.......................................68

4.11 Common chemical constituents and properties................ 72

4.12 Conclusions......................................... 76

5.0 References.............................................. 77 


\section{IILUSTRATIONS}

Figure 1.1-1 Map showing location of Eastern Interior Coal Field......

1.2-1 stratigraphy of the spoon and Carbondale Formations in Illinois.................................. 6

2.1-1 Map showing location of Fulton County study area........ 10

2.2-1 Map showing location of st. Clair County study area...... 12

2.3-1 Map showing location of williamson County study area..... 14

3. 1-1 Hydrographs for Little Cana Creek and Bankston Fork for 1979 water year...........................

3.2-1 Graph showing monthly runoff for Little Cana Creek and

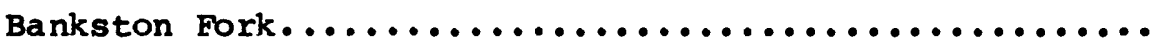

3.3-1 Storm hydrographs of April 12, 1979, for Turkey Creek

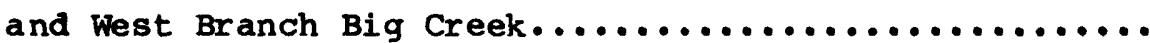

3.4-1 Graph showing flow-duration curves for Little Cana Creek

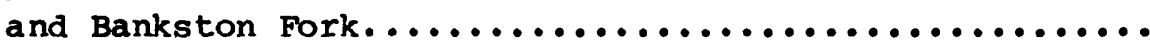

3.4-2 Graph showing variability index comparison, Lane and Iei to Mitchell index, with percent area mined...........

3.5-1 Map showing variability index values adapted from

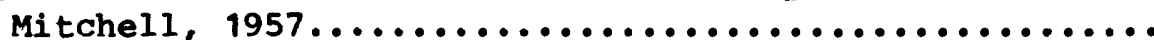

3.5-2 Graph showing synthetic duration curves for Brushy Creek near Harco for different stages of mining.......

4.1-1 Bar diagrams showing variation in concentration of chemical constituents in mined and unmined basins at relatively high and low levels of stream discharge.....

4.2-1 Graph showing relation between dissolved-solids concentration and specific conductance for Doza Creek.......

4.2-2 Graph showing relation between dissolved-solids yield and percentage of the area surface mined for three western Illinois basins........................

4.2-3 Graph showing relation between dissolved-solids yield and percentage of the area surface mined for four southern Illinois basins.......................

4.3-1 Graph showing relation between dissolved sulfate and dissolved-solids concentrations for south Branch Doza Creek...................................

4.3-2 Graph showing relation between dissolved sulfate yield and percent area surface mined for three western Illinois basins.............................

4.3-3 Graph showing relation between dissolved sulfate yield and percent area surface mined for 13 southern Illinois basins.............................. 
Figure 4.4-1 Graph showing relation between dissolved calcium and dissolved solids for South Branch Doza Creek.......... 48

4.4-2 Graph showing relation between dissolved calcium yield and percent area surface mined for western Illinois basins...................................

4.4-3 Graph showing relation between dissolved calcium yield and percent area surface mined for southern Illinois

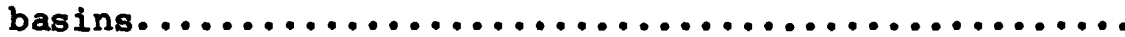

4.5-1 Graph showing generalized harmonic curve for Triplett

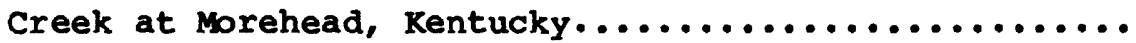

4.6-1 Graph showing duration curve of daily mean discharge of Little Cana Creek......................... 56

4.6-2 Graph showing sediment transport curve for Iittle Cana Creek..................................

4.7-1 Graph showing relation between suspended aluminum and suspended sediment for Little Cana creek.............

4.7-2 Graph showing relation between dissolved aluminum and dissolved solids for South Fork Saline River..........

4.8-1 Graph showing relation between suspended iron and suspended sediment for Little Cana Creek..............

4.9-1 Graph showing relation between dissolved zinc and dissolved solids for south Fork saline River..........

4.9-2 Graph showing relation between dissolved manganese and dissolved solids for South Fork Saline River.......... 
Table 2.3-1 Summary of land uses for the seven study sites.......... 15

3.2-1 Monthly precipitation and runoff, in inches, for Bankston Fork and Little Cana Creek basins.......... 20

3.3-1 Storm characteristics for the seven study sites.......... 24

3.4-1 Computations of variability index for Bankston Fork....... 28

3.4-2 Variability index for the seven study sites............. 29

4.5-1 Harmonic coefficients for the seven study sites.......... 53

4.5-2 Harmonic coefficients for long-term gaging stations....... 54

4.6-1 Computations of mean annual suspended-sediment yield of Little Cana Creek near Creal Springs............ 58

4.10-1 Trace metal concentrations for Little Cana Creek and Bankston Fork.............................. 69

4.10-2 Trace metal concentrations for Turkey Creek and West Branch Big Creek........................... 70

4.10-3 Trace metal concentrations for South Branch Doza Creek and Doza Creek............................. 71

4.11-1 Water-quality data for Little Cana Creek and Bankston Fork............................ 73

4.11-2 Water-quality data for Turkey Creek and West Branch Big Creek.................................. 74

4.11-3 Water-quality data for South Branch Doza Creek and Doza Creek.................................... 
FACTORS FOR CONVERTING INCH-POUND UNITS TO INTERNATIONAI SYSTEM UNITS (SI)

For the convenience of readers who may want to use International system of Units (SI), the data may be converted by using the following factors:

Multiply inch-pound unit

Inch (in.)

foot (ft)

mile (mi)

square mile $\left(\mathrm{mi}^{2}\right)$

cubic foot per second $\left(f t^{3} / s\right)$

cubic foot per second per

square mile $\left[\left(\mathrm{ft}^{3} / \mathrm{s}\right) / \mathrm{mi}^{2}\right]$

ton per square mile (ton $/ \mathrm{mi}^{2}$ )

ton, short

cubic yard $\left(\mathrm{yd}^{3}\right)$

ton per day (ton/day)
By

25.40

0.3048

1.609

2.590

0.02832

0.01093

0.3503

0.9072

0.7646

0.9072
To obtain SI unit

millimeter (mm)

meter (m)

kilometer (km)

square kilometer $\left(\mathrm{km}^{2}\right)$

cubic meter per second $\left(\mathrm{m}^{3} / \mathrm{s}\right)$

cubic meter per second per square kilometer $\left[\left(\mathrm{m}^{3} / \mathrm{s}\right) / \mathrm{km}^{2}\right]$

metric ton per square kilometer (metric ton $/ \mathrm{km}^{2}$ )

megagram (Mg)

cubic meter $\left(\mathrm{m}^{3}\right)$

metric ton per day (metric ton/day)

Degree Fahrenhelt $\left({ }^{\circ} \mathrm{F}\right)$ can be converted to degree celsius $\left({ }^{\circ} \mathrm{C}\right)$ by using

$$
\cdot C=5 / 9(\cdot F-32)
$$

Annual yields in this report are in units of tons per square mile and are computed as follows:

$$
\begin{aligned}
\text { Yield }= & \text { sum of the } 365 \text { daily products of concentrations, in milligrams } \\
& \text { per liter, and runoff, in cubic feet per second-days, times } \\
& 0.0027 \text {, divided by the drainage area, in square miles. }
\end{aligned}
$$




\title{
RUNOFF AND WATER-QUALITY CHARACTERISTICS OF \\ SURFACE-MINED IAANDS IN ILLINOIS
}

By Timothy P. Brabets

\begin{abstract}
Seven watersheds--three in western Illinois (Fulton County), two in southwestern Illinois (St. Clair county), and two in southern Illinois (Williamson County)-were selected to assess the effect of surface mining on the quality and quantity of surface runoff. Each area had one site draining an unmined basin and a nearby site(s) draining a partly surface-mined basin. Data from the literature, file data collected prior to 1979, and streamflow and waterquality data collected from 1977 to 1979 as part of this study, were used to assess runoff characteristics.

Flow-duration curves for streams draining surface-mined land had lower variability than those for streams draining unmined land. By adjusting an index of variability, according to the percentage of surface-mined land in a basin, conventional techniques can be used to develop synthetic flow-duration curves. Surface mining changes basin characteristics such that peak flows are decreased and low flows are increased. Regression equations were developed that relate storm runoff volume and peak discharge to basin characteristics and climatologic data.

Concentrations of dissolved solids, sulfate, and calcium were higher in streams draining areas that were extensively mined than in streams draining areas where mining has been minimal. Different mined areas in Illinois yield different concentrations of these substances. Harmonic analyses of stream temperatures showed higher harmonic means and lower amplitudes in surfacemined basins. Surface-mined basins had lower suspended-sediment yields than unmined basins. Trace-element concentrations were similar in streams in mined and unmined basins provided in-place neutralization by alkaline material had taken place in mined basins.
\end{abstract}




\title{
1.0 Introduction \\ 1.1 Coal Reserves in Illinois
}

\section{ILLINOIS HAS VAST COAL RESERVES}

\author{
Illinois is underlain by vast quantities of coal. \\ Illinois has the largest reserve of bituminous \\ coal in the United States.
}

The energy problem in the United states requires alternatives to the use of oll. One alternative is to increase use of the Nation's vast coal reserves. Coal production is expected to increase, and more than 50 percent of this coal production during the rest of the century may be by surface mining methods.

The coal reserves of Illinois are in the Eastern Interior coal Field, which also includes parts of Indiana and Rentucky (fig. 1.1-1). Estimated coal reserves in Illinols (as of January 1975, with revisions in 1980) are 161.6 billion tons or 15.1 percent of the total demonstrated coal reserves in the United States (Nawrot and others, 1980). Illinois ranks first among the States in total bituminous coal reserves. Only Montana has larger total coal reserves (Rickert and others, 1979). Illinois' reserves also have the highest total heat content of any reserves in the Nation. About 12.1 percent of Illinois' reserves is considered surface minable (coal seams more than 18 inches thick and less than 150 feet deep), but currently only about 3.6 percent is economically and legally recoverable (Nawrot and others, 1980).

In 1979, 40 surface mines in operation in the state produced $26,856,897$ tons of coal, and 31 underground mines produced a total of 32,681,230 tons (Illinois Department of Mines and Minerals, 1980).

Rickert and others (1979) have shown that Illinois' coal resources are among those most likely to be used for synthetic fuel production because of the large amount of coal available, plentiful water supplies, and a favorable geologic environment. 


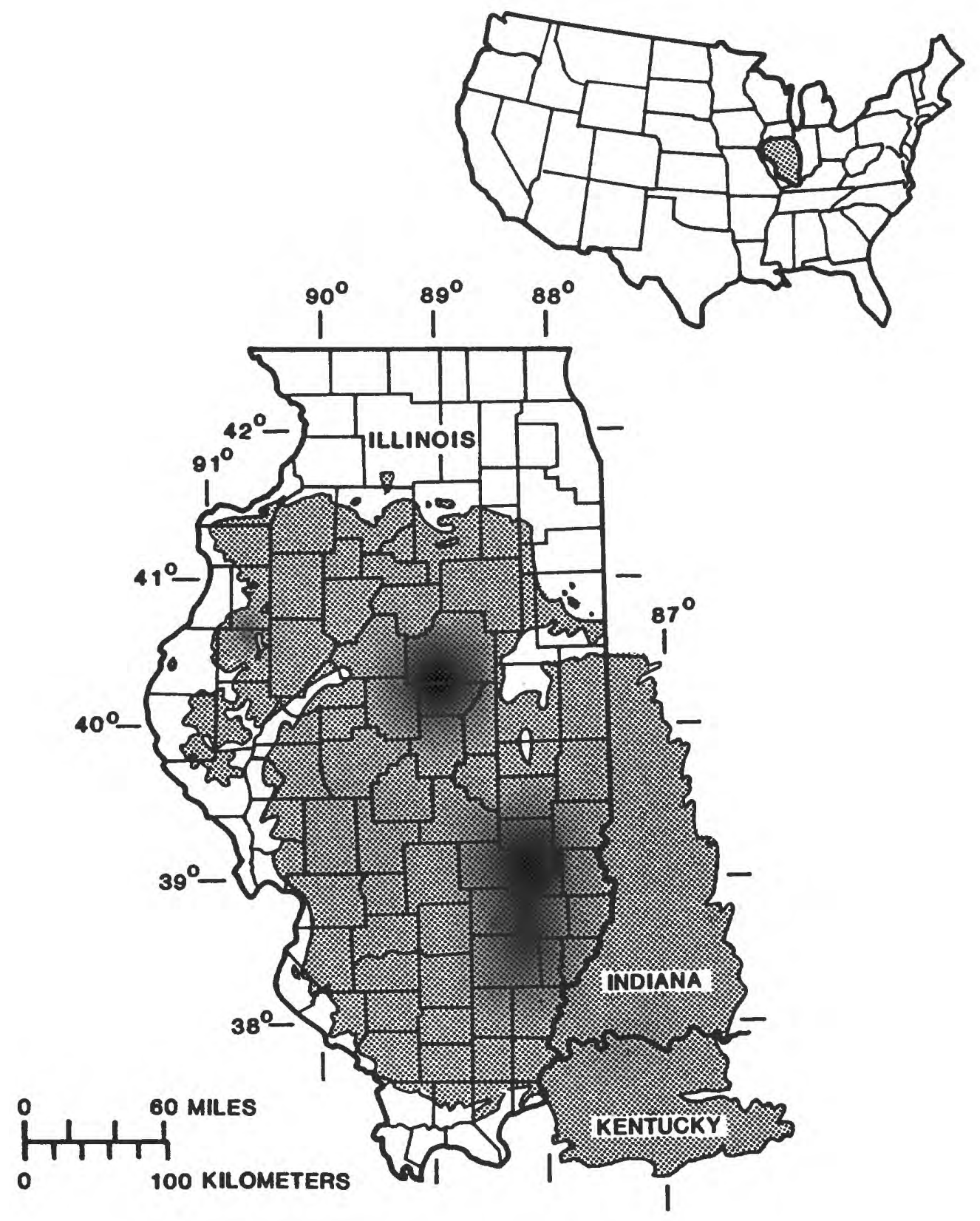

Figure 1.1-1.--Location of Eastern Interior Coal Field. 
1.0 Introduction

1.2 Geologic formations

TWO PRIMARY COAL FORMATIONS--THE SPOON FORMATION
AND THE CARBONDALE FORMATION

Coals of economic importance lie in the spoon and the Carbondale Formations.

Coals of the spoon Formation (fig. 1.2-1) are the earliest widely distributed coals of Pennsylvanian (Des Moinesian) age in Illinois. Coals of economic importance are:

(a) New Burnside Coal Member - well developed coal, but outcrops are scattered. It is up to 5 feet thick.

(b) Murphysboro Coal Member - is present in southeastern Illinois and is up to 7 feet thick.

(c) De Long Coal Member - more than 2 feet thick in a few places. This coal is present at various locations throughout southern Illinois, but is more extensive in western Illinois.

(d) Wise Ridge Coal Member - widely distributed. It is too thin to be mined economically in most of southern Illinois.

(e) Davis Coal Member - a major coal in southern Illinois. It averages about 4 feet in thickness and is prevalent in southeastern Illinois, where it has been extensively mined.

(f) De Koven Coal Member - is present from 3 to 40 feet above the Davis coal, and the two coal members commonly are mined together. The De Koven coal averages 3 feet in thickness and is present mainly in southeastern Illinois.

Coals of the Carbondale Formation are defined as those between the base of the Colchester (No. 2) Coal Member and the top of Danville (No. 7) Coal Member. The principal coals of the Carbondale Formation are:

(a) Colchester (No. 2) Coal Member - coal that has a maximum thickness of 18 inches. It is present throughout Illinois.

(b) Shawneetown coal Member - generally thin but has been reported as up to 8 feet thick in a few scattered drill holes in southeastern Illinois.

(c) Summum (No. 4) Coal Member - generally thin throughout Illinois. The coal is reported to have maximum thickness of 3 feet. 
(d) Harrisburg-Springfield (No. 5) Coal Member - second in commercial importance in Illinois. It lies 50 to 80 feet above the No. 4; the lower end of this range is more common in southwestern Illinois. The coal may be more than 7 feet thick and is present throughout Illinois.

(e) Briar Hill (No. 5A) Coal Nember - thin, discontinuous coal of little commercial importance. It is present only in southeastern and eastern Illinois.

(f) Herrin (No. 6) Coal Nember - bright-banded coal, which ranks first in commercial importance in the state. The coal ranges from 4 to 9 feet in thickness. 


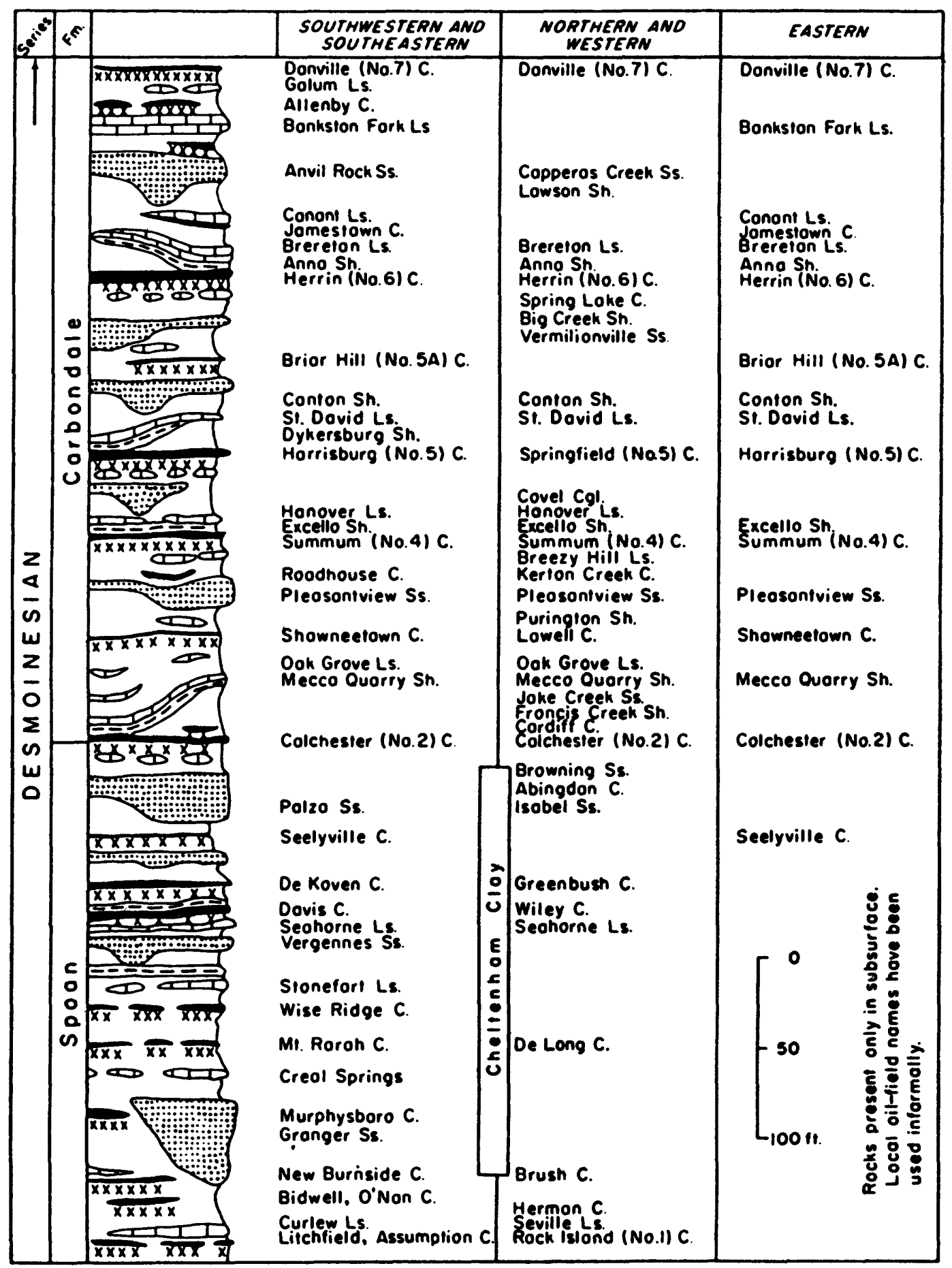

Figure 1.2-1.--Stratigraphy of the Spoon and Carbondale Formations in Illinois (from Willman and others, 1975, p. 166). 
1.0 Introduction

1.3 History and Laws

\section{SURFACE MINING IN ILLINOIS DATES BACK TO 1866 - LEGISLATION BEGAN IN 1962}

Illinois lands have been surface mined since 1866.
The first Illinois mining law was passed in 1962 .

Illinois coals have been surface-mined since 1866. By 1898, 889 mines were in operation throughout 52 counties, with an annual production of 23 million tons. According to the 1979 Illinois Bureau of Mines and Minerals Annual Coal Report, 71 mines that were operated in 1979 produced over 59 million tons of coal.

Most coal in Illinois is mined with draglines and shovels. The capacities of the equipment range from 10 to 185 cubic yards per bucket. Coal seams are uncovered by removing successive strips of overburden; the strips are 40 to 200 feet wide and 20 to 100 feet thick. Successive cuts are made, resulting in the deposition of overburden in long parallel ridges. The process continues until the overburden becomes so thick that coal can no longer be mined economically. The final cut leaves an open trench that can be made into a water impoundment.

No regulatory statutes were applicable to surface-mined lands until January 1, 1962, when the Illinois General Assembly produced the open Cut Land Reclamation Act. The Act imposed some modest requirements for reclamation; however, plans for reclamation were not required until long after the mining began. Performance bonds were low and were often forfeited in preference to reclaiming the land.

In 1971, the Surface-Mined Land Conservation and Reclamation Act was passed by the State. This Act strengthened standards, involved local governments in planning reclamation, increased bonds and fees, and provided for reclamation to row-crop agricultural land. Complete reclamation plans and environmental impact statements were required before mining began.

With the passage of the Surface Mining Control and Reclamation Act of 1977 (Public Law 95-87) on August 3, 1977, mining companies were "required to minimize the disturbance to the prevailing hydrologic balance at the mine site and in associated offsite areas and the quality and quantity of water in surfaceand ground-water systems both during and after surface coal-mining operations." 
1.0 Introduction

1.4 Problem and Purpose

\author{
FEW DATA AVAILABLE TO ASSESS RUNOFF \\ FROM SURFACE-MINED AREAS
} Few data are available to assess the quantity and quality
of runoff from surface-mined land in Illinois.

Few data are available to assess the effects of surface mining on runoff. It is a common belief that changes in the topography and physical characteris$t i c s$ of the disturbed overburden tend to dampen extreme-flow characteristics of surface runoff. The effect of mining on flow extremes needs to be evaluated.

Similarly, the chemical constituents in runoff could be different in areas affected by mining. Some minerals that are stable in the subsurface environment become unstable when exposed to weathering agents and thus have greater potential to become dissolved in runoff.

The U.S. Geological Survey began an intensive program in 1977 to evaluate the effects of surface mining in selected watersheds. The purpose of this program was: (1) to determine the differences in stream runoff caused by surface mining, and (2) to define chemical concentrations and loads contributed to surface runoff by surface-mined areas.

Runoff characteristics such as peak flows, mean daily flows, mean daily dissolved solids loads, and annual suspended-sediment yields were determined for small streams and basins in the Illinois coal-mining areas. These characteristics were then compared to characteristics of streams and basins in unmined areas and were quantified based on the percentage of surface-mined land in each stream basin. 


\subsection{Areas of Study 2.1 Western Illinois}

FULTON COUNTY

Three watersheds were selected in Fulton County. One watershed was unmined, one had 29 percent of the land in surface mining, and one had 90 percent of the land in surface mining.

The area of Fulton County is 874 square miles. As of 1967, land use consisted of 57.1 percent cropland, 17.9 percent pasture, 17.2 percent forest, and 7.8 percent other uses (Nawrot and others, 1980, p. 50). The topography of Fulton County consists of level to rolling uplands, ravines, and flood plains. Soils of the Clary-Clinton-Reomah, Joy-Tama-Muscatine-Ipava-Sable, and seaton-Fayette-stronghurst soil associations developed primarily from loess.

There are 366 abandoned underground mines and over 73 square miles of surface-mined lands in Fulton County. Three surface mines were active in the county in 1980 .

Four major coal seams that have been mined in Fulton County are No. 1 (Rock Island), No. 2 (Colchester), No. 5 (Harrisburg-Springfield), and No. 6 (Herrin). The No. 5 seam is the principal coal seam and has an average thickness of 56 inches. Estimated coal reserves of the county exceed 2.2 billion tons, of which 89 percent is considered minable by surface methods.

Three watersheds were selected for study in Fulton County (fig. 2.1-1). All three watersheds are in the Spoon River basin. Turkey Creek drains an unmined watershed of 11.5 square miles. Most of the watershed is farmland ( 87 percent), and the remainder is forest. West Branch Big Creek near Canton has a drainage area of 4.31 square miles. Twenty-nine percent of its area was surface mined from 1970 to 1975 . The remainder of the watershed is farmand. The third site, slug Run near Bryant, drains 7.12 square miles. Ninety percent of its area was mined by surface methods before 1962.

Gaging stations on Turkey Creek and West Branch Big Creek were equipped to obtain records of streamflow, rainfall, water temperature, and specific conductance. At both stations, water samples were collected monthly and more frequently during high flows. Two additional rain gages were located within Turkey Creek watershed to define the distribution of rainfall. Records of streamflow, water temperature, specific conductance, and water quality have been collected at a gaging station on slug Run since 1975. 


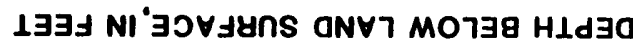
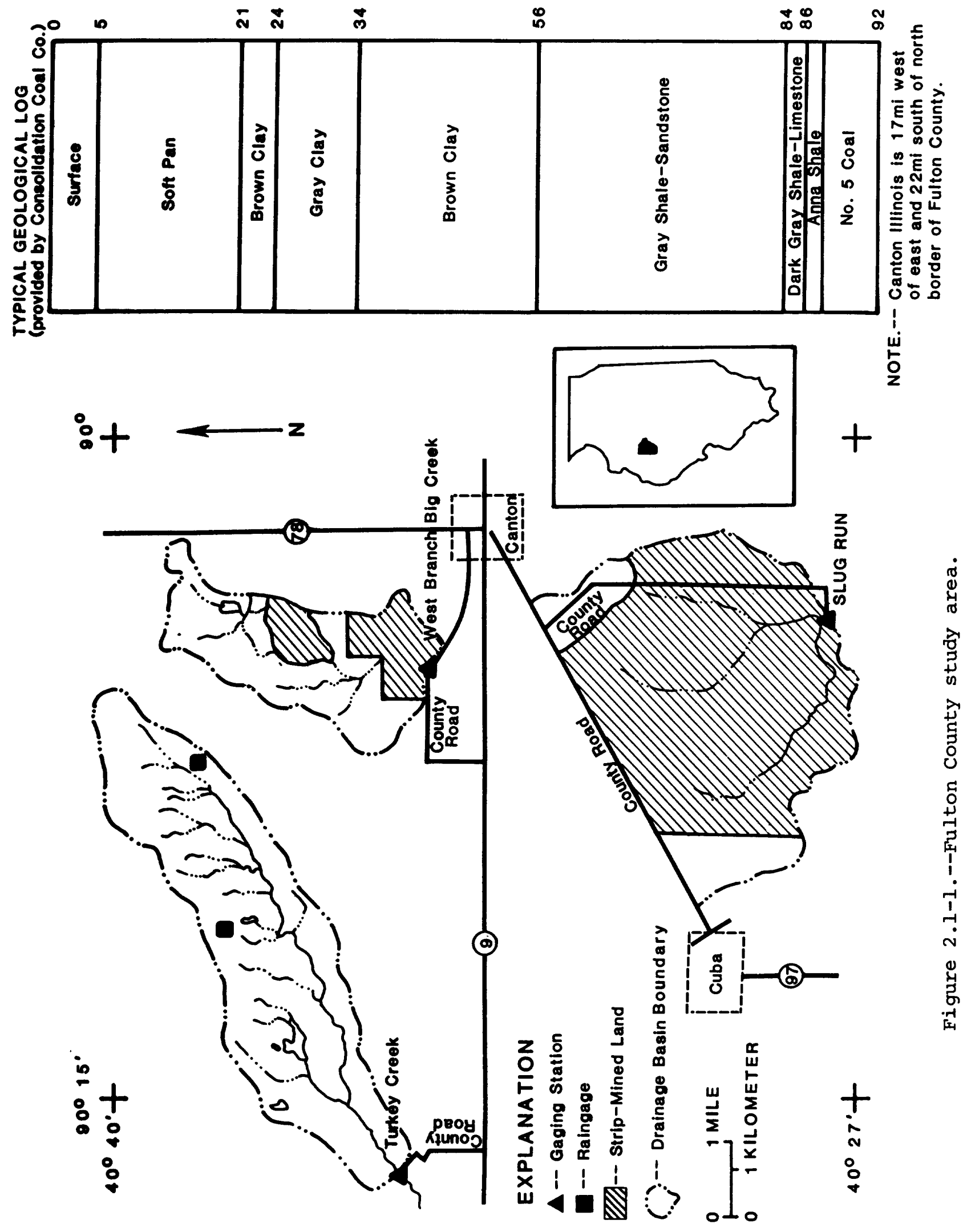


\subsection{Areas of Study \\ 2.2 Southwestern Illinois}

\section{ST. CLAIR COUNTY}

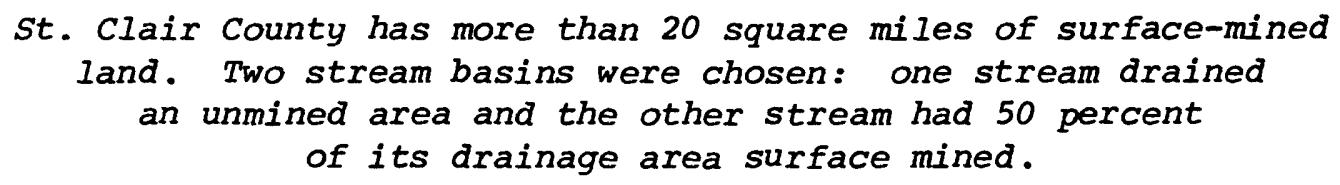

The area of St. Clair county is 670 square miles. Land use includes cropland ( 61.2 percent), pasture ( 5.2 percent), forest ( 13.6 percent), and other uses (20.0 percent). The topography consists of level to rolling uplands, flood plains, river bluffs, and ravines. Soils in the county, which developed primarily from loess, form the Stookey-Alford-Muren, Hosmer-Stoy-Weir, Oconee-Cowden-Piasa, and Harrison-Herrick-Virden soil associations.

More than 20 square miles of land have been surface mined in st. Clair county. There was one active surface mine in 1980. All surface-mining operations extracted the Herrin (No. 6) coal at depths less than 100 feet. Estimates of coal reserves exceed 2.9 billion tons, of which 36.2 percent is considered minable by surface methods.

Two watersheds in St. Clair county were selected for hydrologic monitoring (fig. 2.2-1). Both sites are in the Kaskaskia River basin. South Branch Doza Creek near Lenzburg drains an unmined basin of 7.9 square miles. Land use is primarily farmland ( 96.0 percent), and the remainder is forest. Doza Creek near Lenzburg drains 18.4 square miles. Fifty percent of this watershed was surface mined from 1963 to 1973. Gaging stations on both streams were equipped with recorders to obtain water discharge, rainfall, water temperature, and specific conductance. Water samples were collected monthly and during high flows. Three additional rain gages were placed within the basins to monitor the distribution of rainfall. 


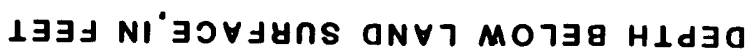
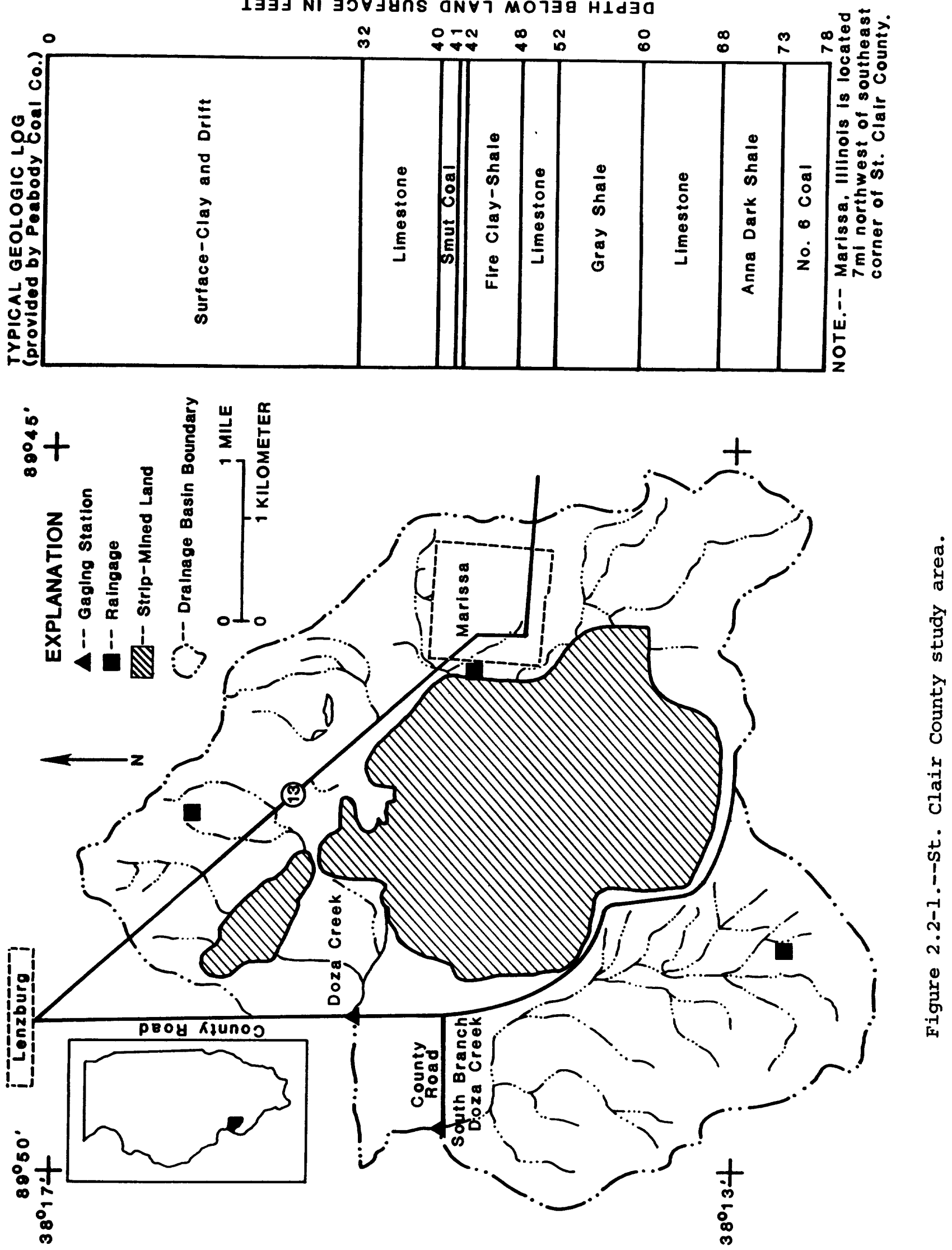
2.0 Areas of Study

2.3 Southern Illinois

WILLIAMSON COUNTY

Twenty-three square miles, more than 5 percent of the land in williamson County, has been surface mined. Two watersheds were studied; one was an unmined area of 1.46 square miles, and the other an area of 1.9 square miles, of which 99 percent has been surface mined.

The area of Williamson County is 424 square miles. Land use consists of cropland (28.6 percent), pasture (18.7 percent), forest (23.3 percent), and other uses (29.4 pecent). Topographical features include a rolling till plain, ravines, and flood plains. Loess and outwash material developed into soils of the Ava-Bluford-Wynoose, Hosmer-Stoy-Weir, Hoyleton-Cisne-Huey, and Grantsburg-Robbs-Wellston soil associations.

More than 23 square miles of land has been surface mined in williamson County and as of 1978, there were 15 active surface mines. The HarrisburgSpringfield (NO. 5) and Herrin (No. 6) coal seams have been surface mined. The Danville (No. 7) and Davis-De Koven seams have also been mined at depths less than 75 feet. Estimates of coal reserves are 3.1 billion tons, of which 17.9 percent is considered minable by surface methods.

Two hydrologic monitoring sites were established in williamson county (fig. 2.3-1), both in the Saline River basin. Little Cana Creek near Creal Springs drains a 1.46-square-mile watershed. Most of the area is farmland $(80$ percent); the remainder is forest. Bankston Fork near Crab orchard drains 1.90 square miles. Ninety-nine percent of the drainage area was surface mined between 1944 and 1958.

Both sites were equipped to obtain records of streamflow, rainfall, water temperature, and specific conductance. An additional rain gage was placed in the Bankston Fork watershed to help define the distribution of rainfall. water samples were taken monthly and during periods of high flow.

Table 2.3-1 summarizes the land uses for the seven study watersheds. Data for all sites were published in Water Resources Data Report for Illinois, Volumes 1 and 2, water year 1980 (U.S. Geological Survey, 1981). 


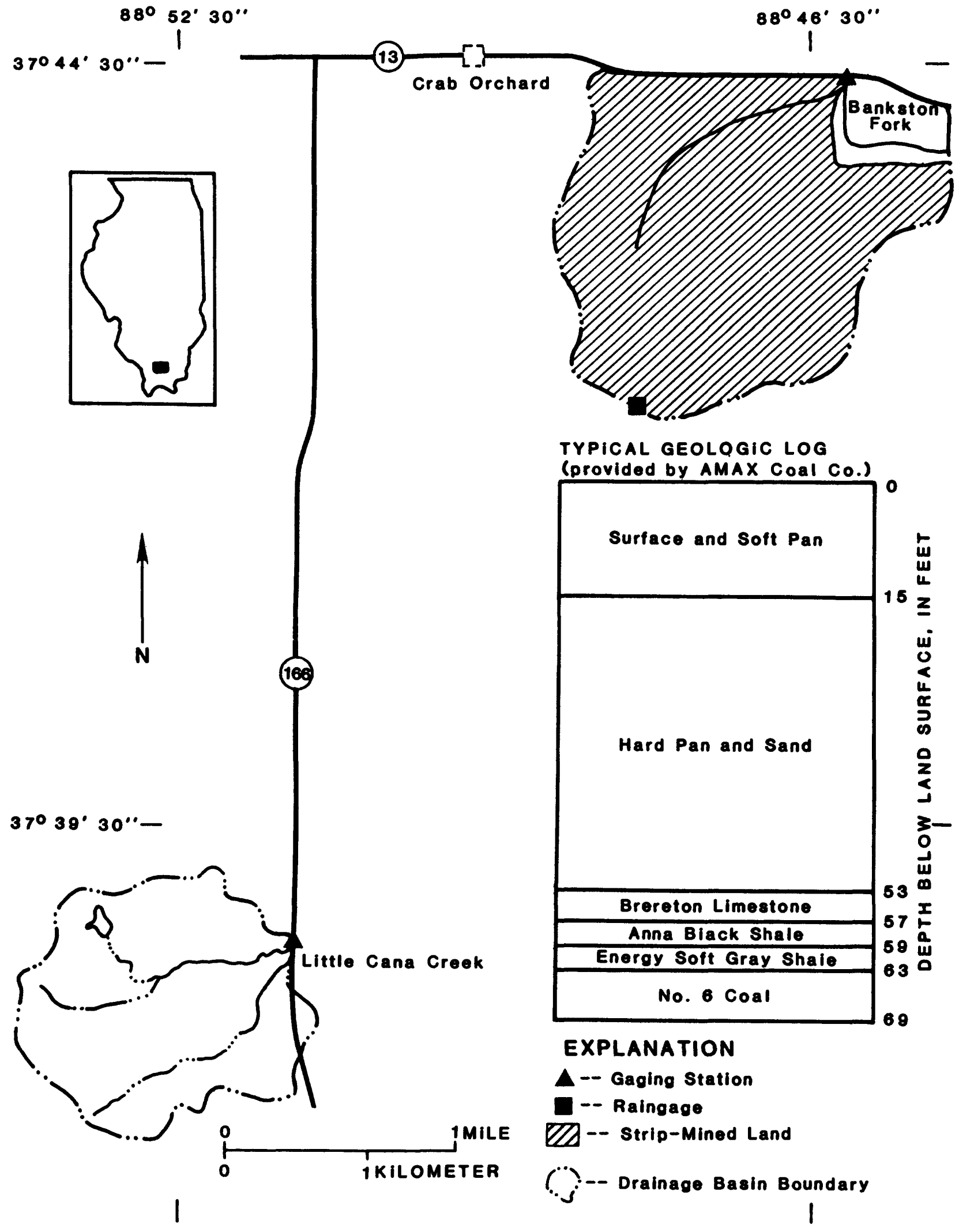

Figure 2.3-1.--Williamson County study area. 
Table 2.3-1 summary of land uses for the seven study sites

\begin{tabular}{|c|c|c|c|c|c|}
\hline \multirow{2}{*}{$\begin{array}{c}\text { USGS } \\
\text { station } \\
\text { number }\end{array}$} & \multirow[b]{2}{*}{ Stream name } & \multirow{2}{*}{$\begin{array}{c}\text { Drainage } \\
\text { area } \\
\left(\mathrm{mi}^{2}\right) \\
\end{array}$} & \multicolumn{3}{|c|}{ Iand use, in percent } \\
\hline & & & $\begin{array}{l}\text { Farm } \\
\text { land }\end{array}$ & Forest & $\begin{array}{c}\text { Surface } \\
\text { mined }\end{array}$ \\
\hline 03382045 & $\begin{array}{l}\text { Little Cana Creek } \\
\text { near Creal Springs }\end{array}$ & 1.46 & 80 & 20 & 0 \\
\hline 03382160 & $\begin{array}{l}\text { Bankston Fork } \\
\text { near Crab orchard }\end{array}$ & 1.90 & 0 & 1 & 99 \\
\hline 05569968 & $\begin{array}{l}\text { Turkey Creek } \\
\text { near Fiatt }\end{array}$ & 11.5 & 87 & 13 & 0 \\
\hline 05570330 & $\begin{array}{l}\text { West Branch Big Creek } \\
\text { near Canton }\end{array}$ & 4.31 & 71 & 0 & 29 \\
\hline 05570380 & Slug Run near Bryant & 7.12 & 5 & 5 & 90 \\
\hline 05595226 & $\begin{array}{l}\text { Doza Creek near } \\
\text { Lenzburg }\end{array}$ & 18.4 & 50 & $\mathbf{0}$ & 50 \\
\hline 05595228 & $\begin{array}{l}\text { South Branch Doza } \\
\text { Creek near Lenzburg }\end{array}$ & 7.90 & 96 & 4 & 0 \\
\hline
\end{tabular}




\title{
3.0 Surface Water
}

3.1 Streamflow Characteristics

\section{STREAMFLOW CHARACTERISTICS VARIED}

\author{
Discharge hydrographs show many differences in streamflow \\ characteristics between unmined and mined lands.
}

The discharge hydrographs for the 1979 water year for two streams in williamson county (fig. 3.1-1) show differences in flow characteristics of mined and unmined watersheds. Unmined watersheds such as Iittle Cana Creek have comparatively high and sharp peak discharges, whereas mined basins, such as Bankston Fork, have comparatively low peak discharges. In most unmined basins, flow approaches zero or is extremely low during the summer; most of the mined basins have higher flows during the summer than do unmined basins.

High flows, low flows, and other discharge characteristics were studied in detail for all sites. This section presents the results of these studies, and discusses the differences and similarities of the streamflow characteristics between mined and unmined agricultural basins. Some techniques are presented that may be useful in estimating changes in runoff characteristics influenced by surface mining. 


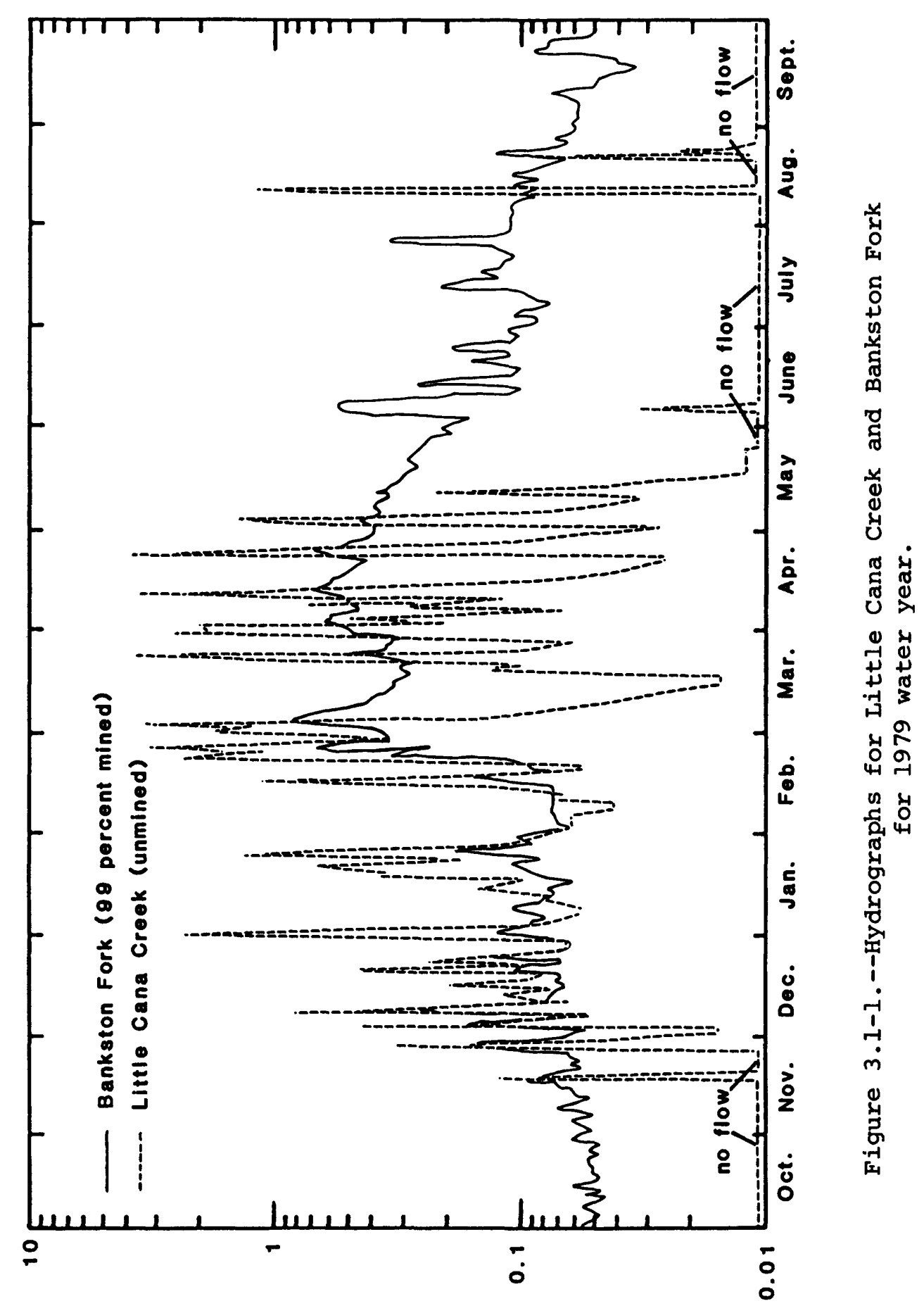

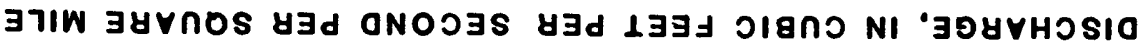




\title{
3.0 Surface Water
}

3.2 Precipitation and Runoff

\section{VOLUME OF RUNOFF DIFFERS BETWEEN MINED BASINS AND UNMINED AGRICULTURAL BASINS}

\author{
Although monthly precipitation was nearly equal in both \\ mined and unmined basins, differences in monthly \\ runoff between basins are noticeable.
}

Monthly precipitation data (table 3.2-1) in the Bankston Fork (mined) and Iittle Cana Creek (unmined) basins in Williamson County (southern Illinois) were fairly uniform from May 1978 to April 1980. Notable exceptions are June and August of 1979, when storms affected only the Little Cana Creek basin. Runoff from Bankston Fork totaled 17.13 inches from May 1978 to April 1979, and 12.22 inches from May 1979 to April 1980. Runoff from Little Cana Creek totaled 22.72 inches from May 1978 to April 1979 and 11.09 inches from May 1979 to April 1980 .

For the sites in st. Clair and Fulton counties (southwestern and western Illinois) precipitation was evenly distributed over the mined and unmined basins. Precipitation totaled 40 inches from June 1978 to May 1979 and 29 inches from June 1979 to May 1980 for the sites in St. Clair county (southwestern Illinois), and 38 inches from April 1978 to March 1979 and 25 inches from April 1979 to March 1980 for the sites in Fulton County (western Illinois). In southwestern Illinois, runoff from the mined basin (Doza Creek) was greater (20 inches total for 2 years) than the unmined basin (South Branch Doza Creek, which had 14 inches total for 2 years). In western Illinois, all three basins had nearly equal runoff (Turkey Creek--19 inches total for 2 years, West Branch Big Creek--21 inches total for 2 years, and slug Run--18 inches total for 2 years).

Although no differences were apparent in yearly runoff between mined and unmined basins, notable differences in monthly runoff were observed. Figure 3.2-1 shows a graph of monthly runoff for Little Cana. Creek and Bankston Fork. Runoff during the summer and fall months was higher for the mined basin (Bankston Fork). During the spring and winter months the unmined basin (Iittle Cana Creek) had more runoff. similar differences were also noted in the other two study areas. The unmined basins consist primarily of farmland; thus, differences in runoff patterns could result from the difference between mining and agricultural practices rather than being typical of unmined versus mined lands. 


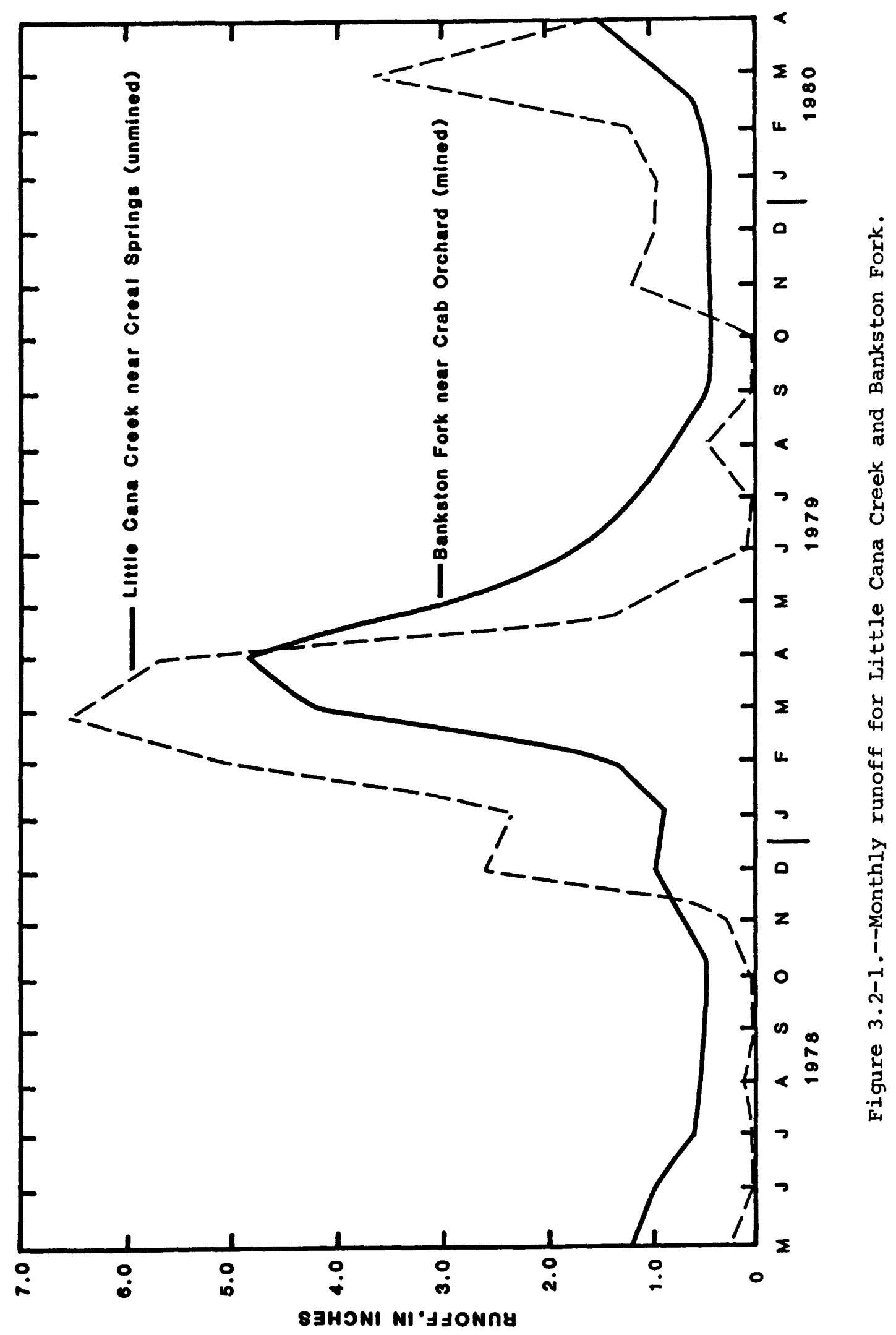


Table 3.2-1 Monthly precipitation and runoff, in inches, for Bankston Fork and Iittle Cana Creek basins

\begin{tabular}{|c|c|c|c|c|c|c|}
\hline \multirow{3}{*}{$\begin{array}{c}\text { Month } \\
\text { and } \\
\text { year }\end{array}$} & \multicolumn{4}{|c|}{ Bankston Fork } & \multirow{2}{*}{$\begin{array}{l}\text { Little Ca } \\
\text { Precipi- } \\
\text { tation }\end{array}$} & \multirow{3}{*}{$\begin{array}{l}\text { Creek } \\
\text { Runof } \mathrm{f}\end{array}$} \\
\hline & \multicolumn{3}{|c|}{ Precipitation 1} & \multirow[t]{2}{*}{ Runoff } & & \\
\hline & Gage 1 & Gage 2 & Average & & Gage 1 & \\
\hline \multicolumn{7}{|l|}{1978} \\
\hline May & 2.12 & -- & 2.12 & 1.18 & 2.23 & 0.30 \\
\hline June & .93 & -- & .93 & 1.00 & .91 & .00 \\
\hline July & 1.90 & -- & 1.90 & .60 & 1.65 & .00 \\
\hline August & 6.07 & 6.15 & 6.11 & .57 & 6.27 & .14 \\
\hline September & .70 & .88 & .79 & .54 & .68 & .00 \\
\hline October & 1.20 & 1.25 & 1.22 & .51 & 1.13 & .00 \\
\hline November & 5.46 & 5.73 & 5.60 & .77 & 5.35 & .28 \\
\hline December & 5.49 & 6.41 & 5.95 & .94 & 5.61 & 2.60 \\
\hline \multicolumn{7}{|l|}{1979} \\
\hline January & 1.27 & -- & 1.27 & .91 & 1.38 & 2.40 \\
\hline February & 3.87 & -- & 3.87 & 1.31 & 4.16 & 4.80 \\
\hline March & 5.48 & 5.72 & 5.60 & 4.00 & 6.06 & 6.50 \\
\hline April & 6.81 & 6.86 & 6.83 & 4.80 & 6.89 & 5.70 \\
\hline TOTAL & & & 42.19 & 17.13 & 42.32 & 22.72 \\
\hline May & 2.78 & 2.68 & 2.73 & 3.00 & 3.52 & 1.20 \\
\hline June & 3.68 & 3.66 & 3.67 & 1.80 & 6.12 & .02 \\
\hline July & 4.33 & 4.56 & 4.44 & 1.20 & 4.13 & .00 \\
\hline August & 2.98 & 3.73 & 3.35 & .80 & 5.70 & .47 \\
\hline September & 1.32 & 1.43 & 1.38 & .50 & .30 & .00 \\
\hline October & 1.98 & 2.10 & 2.04 & .45 & 2.35 & .00 \\
\hline November & 6.00 & 5.91 & 5.95 & .44 & 5.77 & 1.17 \\
\hline December & 2.04 & 2.04 & 2.04 & .49 & 2.18 & .99 \\
\hline \multicolumn{7}{|l|}{1980} \\
\hline January & 1.43 & 1.23 & 1.33 & .44 & 1.32 & .95 \\
\hline February & 1.16 & 1.47 & 1.31 & .56 & .95 & 1.22 \\
\hline March & 4.02 & 4.53 & 4.28 & .98 & 4.05 & 3.57 \\
\hline April & 2.05 & 2.57 & 2.31 & 1.56 & 2.05 & 1.50 \\
\hline TOTAL & & & 34.83 & 12.22 & 38.44 & 11.09 \\
\hline
\end{tabular}

1 Locations of precipitation gages are shown in figure 2.3-1. 


\title{
3.0 Surface Water \\ 3.3 Storm Runoff
}

\section{STORM RUNOFF AND PEAK DISCHARGES DECREASE WITH INCREASING AREA OF SURFACE MINING}

\author{
Storm-runoff volumes and peak discharges were reduced as \\ a result of surface mining. Equations were developed \\ to predict runoff volumes and peak discharges from \\ surface-mined basins.
}

A typical storm rainfall-runoff hydrograph is shown in figure 3.3-1. It shows that flow in Turkey creek, which drains an unmined basin, had a higher and sharper peak than flow in west Branch Big Creek, which drains a mined basin. Also, storm-runoff volumes are considerably less from mined basins than from unmined basins. Selected storm characteristics are 1isted in table 3.3-1; asterisks $(*)$ indicate peak discharges that correspond to a 2-year flood based on an equation by curtis (1977).

Multiple-regression techniques were used to develop relations for volume and peak discharge. Stepwise regression was used and the level of significance to enter each variable was 0.15 . The following equations were developed:

$$
\begin{aligned}
& \text { VOL }=3.02 \text { PTOT }^{1.35} \text { QINIT }^{0.353} x^{-0.641} \\
& \text { QPEAK }=58.6 \text { AREA }^{-0.402} \text { PTOT }^{0.982} \text { QINIT }^{0.221} x^{-0.682}
\end{aligned}
$$

where

$$
\begin{aligned}
& \text { VOL = } \text { volume of storm runoff, in inches; } \\
& \text { QPEAK = peak discharge, in cubic feet per second; } \\
& \text { AREA = drainage area of the basin, in square miles; } \\
& \text { PTOT = } \text { average total depth of precipitation over the drainage area } \\
& \text { during the storm, in inches; } \\
& \text { QINIT = } \text { initial discharge, in cubic feet per second, before precipitation } \\
& \text { began; } \\
&= \text { indicator variable having a value of } 0 \text { for a mined basin and a } \\
& \text { value of } 1 \text { for an unmined basin. }
\end{aligned}
$$

For both equations, sample size equaled 52. The following independent variables: mined area in the basin, drainage density, age of the mines, antecedent precipitation index, storm duration, air temperature, channel slope, and area of lakes in the basin, did not pass the test to enter regression analysis. Most of the parameters in the equations are significant at the 95 percent confidence level, especially $x$, the indicator variable. 
The estimating equations developed have high standard errors of estimate (greater than 90 percent for both equations) and should be used with caution. However, it is important to note that the designation of a basin as mined or unmined is significant as evidenced by the negative coefficient of $x$ in both equations and its level of significance. The equations could probably be further improved if other characteristics were known such as the type of mine spoil material or the storage capacity of lakes in the basin. 


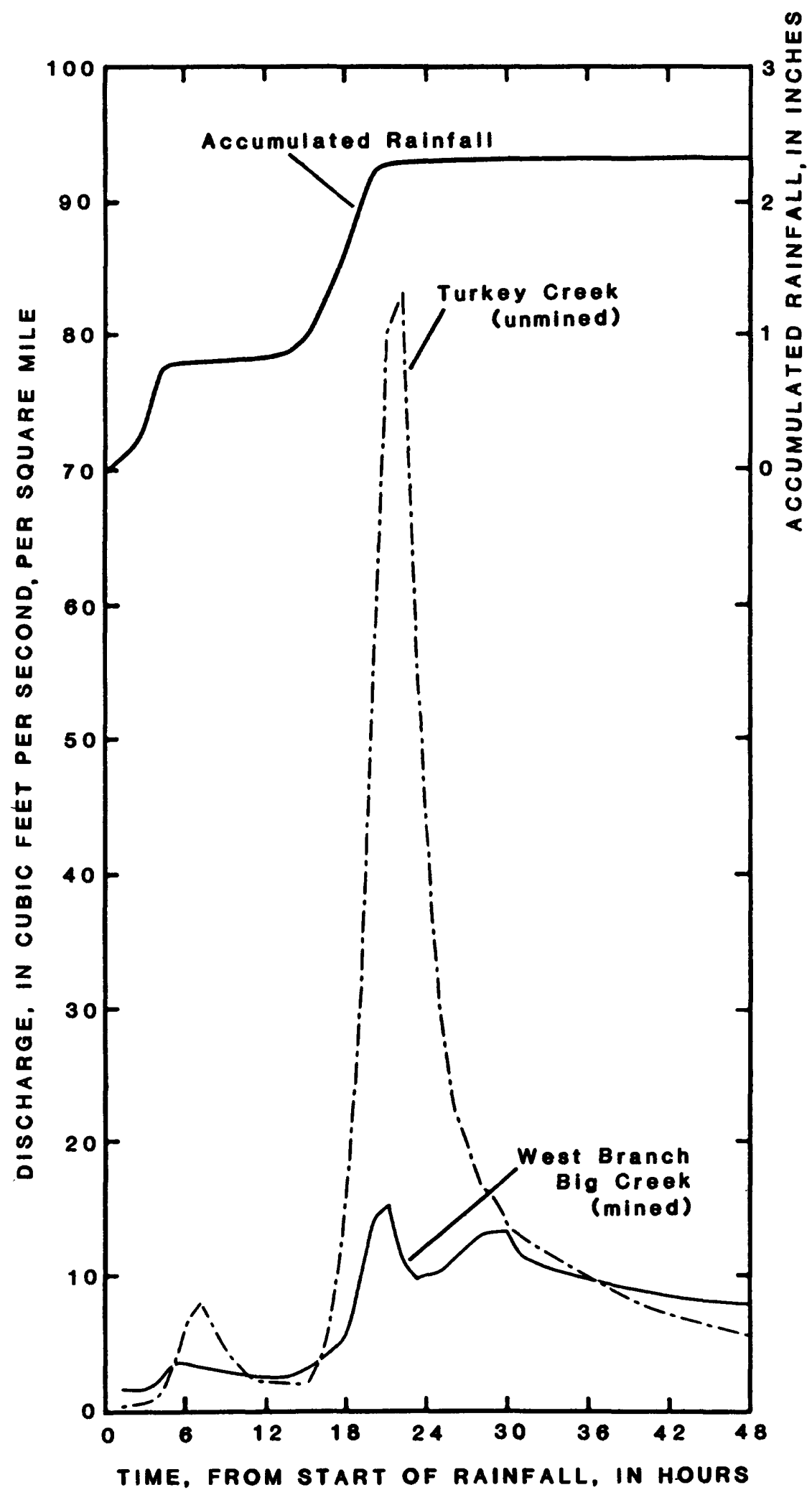

Figure 3.3-1.--Storm hydrographs of April 12, 1979, for Turkey Creek and West Branch Big Creek. 
rable 3.3-1 storm characterletice for the seven study stes

\begin{tabular}{|c|c|c|c|c|c|}
\hline station & Date & $\begin{array}{l}\text { Raine all } \\
\text { (Inches) }\end{array}$ & $\begin{array}{l}\text { Runofe } \\
\text { volume } \\
\text { (Inches) }\end{array}$ & $\begin{array}{c}\text { Peak } \\
\text { Alecharge } \\
\left(\left(\in t^{3} / \mathrm{s}\right) / \mathrm{mi}^{2}\right)\end{array}$ & $\begin{array}{c}\text { In } 1 t \text { lal } \\
\text { discharge } \\
{\left[\left(\varepsilon t^{3} / a\right) / a L^{2}\right]}\end{array}$ \\
\hline \multirow{8}{*}{$\begin{array}{l}\text { Little Cana } \\
\text { Creok }\end{array}$} & $03-22-78$ & 1.61 & 1.10 & 199 & 0.6 \\
\hline & $04-11-79$ & 1.31 & .97 & - 393 & 1.2 \\
\hline & $04-23-79$ & 2.08 & 1.49 & 199 & .2 \\
\hline & $05-03-79$ & .93 & .31 & 43.0 & .3 \\
\hline & $08-11-79$ & 2.54 & .45 & 195 & .0 \\
\hline & $11-08-79$ & $: 73$ & .10 & 23.4 & .1 \\
\hline & $11-25-79$ & 1.15 & .28 & 33.1 & .6 \\
\hline & $03-16-80$ & 1.48 & .66 & 190 & .5 \\
\hline \multirow{8}{*}{$\begin{array}{l}\text { Banketon } \\
\text { Pork }\end{array}$} & $12-07-78$ & 1.08 & .09 & 3.6 & .8 \\
\hline & $03-22-79$ & 1.20 & .03 & 6.8 & 2.2 \\
\hline & $04-11-79$ & 1.31 & .10 & 13.1 & 3.8 \\
\hline & $04-23-79$ & 2.08 & .09 & 10.0 & 3.7 \\
\hline & $05-03-79$ & .93 & .02 & 5.4 & 3.8 \\
\hline & $11-08-79$ & .72 & .06 & 7.5 & .7 \\
\hline & $11-25-79$ & 1.15 & .04 & 5.8 & 4.5 \\
\hline & $03-16-80$ & .90 & .13 & 15.8 & .5 \\
\hline \multirow{8}{*}{$\begin{array}{l}\text { Turkey } \\
\text { Crook }\end{array}$} & $04-10-78$ & 1.41 & .67 & 26.5 & 2.7 \\
\hline & $05-07-78$ & 1.84 & .31 & 10.4 & 1.0 \\
\hline & $05-12-78$ & 2.10 & 1.00 & 38.7 & 2.3 \\
\hline & $07-01-78$ & 1.98 & .24 & 17.2 & .3 \\
\hline & $03-19-79$ & .83 & .30 & 18.4 & 5.6 \\
\hline & $03-29-79$ & 1.35 & .43 & 29.2 & 1.6 \\
\hline & $04-11-79$ & 2.24 & .85 & .80 .4 & .7 \\
\hline & $07-24-79$ & 3.15 & .22 & 27.4 & .1 \\
\hline \multirow{8}{*}{$\begin{array}{l}\text { West Branch } \\
\text { BIg Creek }\end{array}$} & $04-10-78$ & 1.41 & .41 & 16.0 & 3.1 \\
\hline & $05-07-78$ & 1.32 & .14 & 6.8 & 2.2 \\
\hline & $05-12-78$ & 2.10 & .52 & 13.9 & 4.2 \\
\hline & $07-01-78$ & 1.98 & .02 & 9.7 & .3 \\
\hline & $03-19-79$ & .83 & .13 & 10.6 & 2.8 \\
\hline & $03-29-79$ & 1.35 & .14 & 5.4 & 2.6 \\
\hline & $04-11-79$ & 2.24 & .45 & 16.2 & 1.9 \\
\hline & $07-24-79$ & 3.17 & .04 & 5.7 & .01 \\
\hline \multirow[t]{8}{*}{ slug Pun } & $04-10-78$ & 1.54 & .37 & 17.7 & 3.3 \\
\hline & $05-07-78$ & 1.82 & .19 & 5.6 & 1.5 \\
\hline & $05-12-78$ & 1.36 & .18 & 15.0 & 3.3 \\
\hline & $07-01-78$ & 1.54 & .14 & 12.3 & .4 \\
\hline & $03-19-79$ & .83 & .19 & 12.3 & 2.2 \\
\hline & $03-29-79$ & 1.35 & .05 & 5.3 & 1.5 \\
\hline & $04-11-79$ & 2.24 & .49 & 36.8 & 1.4 \\
\hline & $07-24-79$ & 3.17 & .06 & 3.8 & .2 \\
\hline \multirow{6}{*}{$\begin{array}{l}\text { South Branch } \\
\text { Doza Creok }\end{array}$} & $11-25-78$ & 1.86 & .10 & 4.9 & .1 \\
\hline & $03-20-79$ & 1.49 & .26 & 29.3 & .4 \\
\hline & $03-22-79$ & 1.65 & .83 & 31.1 & .7 \\
\hline & $04-11-79$ & 3.09 & 2.68 & -77.0 & .3 \\
\hline & $07-28-79$ & 4.33 & 1.21 & 52.4 & .1 \\
\hline & $03-30-80$ & 1.03 & .42 & 23.1 & .1 \\
\hline \multirow[t]{6}{*}{ Doza Creok } & $11-25-78$ & 1.53 & .10 & 2.6 & .4 \\
\hline & $03-20-79$ & 1.60 & .24 & 9.8 & 1.2 \\
\hline & $03-22-79$ & 1.72 & .63 & 17.1 & 2.7 \\
\hline & $04-11-79$ & 3.31 & 2.07 & 63.9 & 3.0 \\
\hline & $07-28-79$ & 4.10 & 1.09 & 34.0 & .1 \\
\hline & $03-30-80$ & .95 & .18 & 7.2 & 1.1 \\
\hline
\end{tabular}




\title{
3.0 Surface Water \\ 3.4 Flow Duration and Variability
}

\section{STREAMS DRAINING MINED BASINS HAVE LOWER STREAMFLOW VARIABILITY}

\begin{abstract}
Streams draining mined basins have lower streamflow variability than those draining unmined basins. The percentage reduction in variability index is related to the percentage of drainage area that has been surface mined.
\end{abstract}

Distribution of daily mean flows of a stream can be shown by a flowduration curve. Figure 3.4-1 presents flow-duration curves for Little Cana Creek (unmined) and Bankston Fork (mined). For comparison, flows of each stream were converted to cubic feet per second per square mile. Steep slopes and fewer reverse slopes are characteristic of curves for Little Cana Creek and other streams in unmined basins and indicate large flow variability and low base flows. The curve for Bankston Fork shows that the mined basin produces a higher sustained low flow than that of the unmined basin. At a duration of 50 percent, daily flow per square mile from the mined basin is approximately 10 times greater than from the unmined basin. Little Cana Creek shows higher flood discharges than Bankston Fork. At durations of less than 2 percent, discharges at Iittle Cana Creek are approximately three times as great as those of Bankston Fork.

Lane and Lei (1950) developed a varlabllity index for characterizing flow of a stream. They compute the index as follows: (1) from the curation curve, select values of discharge at 10 percent intervals from 5 percent to 95 percent, (2) compute the logarithms of these values, and (3) compute the standard deviation of these logarithms (index of variability). The method was modified, for streams in which there is zero flow more than 5 percent of the time, to be based on the period which flow exists. An example of the calculation of the variability index for Bankston Fork is shown in table 3.4-1.

The variability indexes for the seven sites were computed using the above method and are given in table 3.4-2. The variability indexes were compared to values from Mitchell's (1957) (section 3.5, fig. 3.5-1) statewide map and with the percent of area mined. The unmined basins agree with Mitchell's values (table 3.4-2). The percentage reduction in variability index is related, for each area, to the percent of area mined (fig. 3.4-2). However, note that this is a tentative relationship based on limited data. Also, the variability index and the flow-duration curves are based on only 2 years of record and are subject to rather large time-sampling errors. 


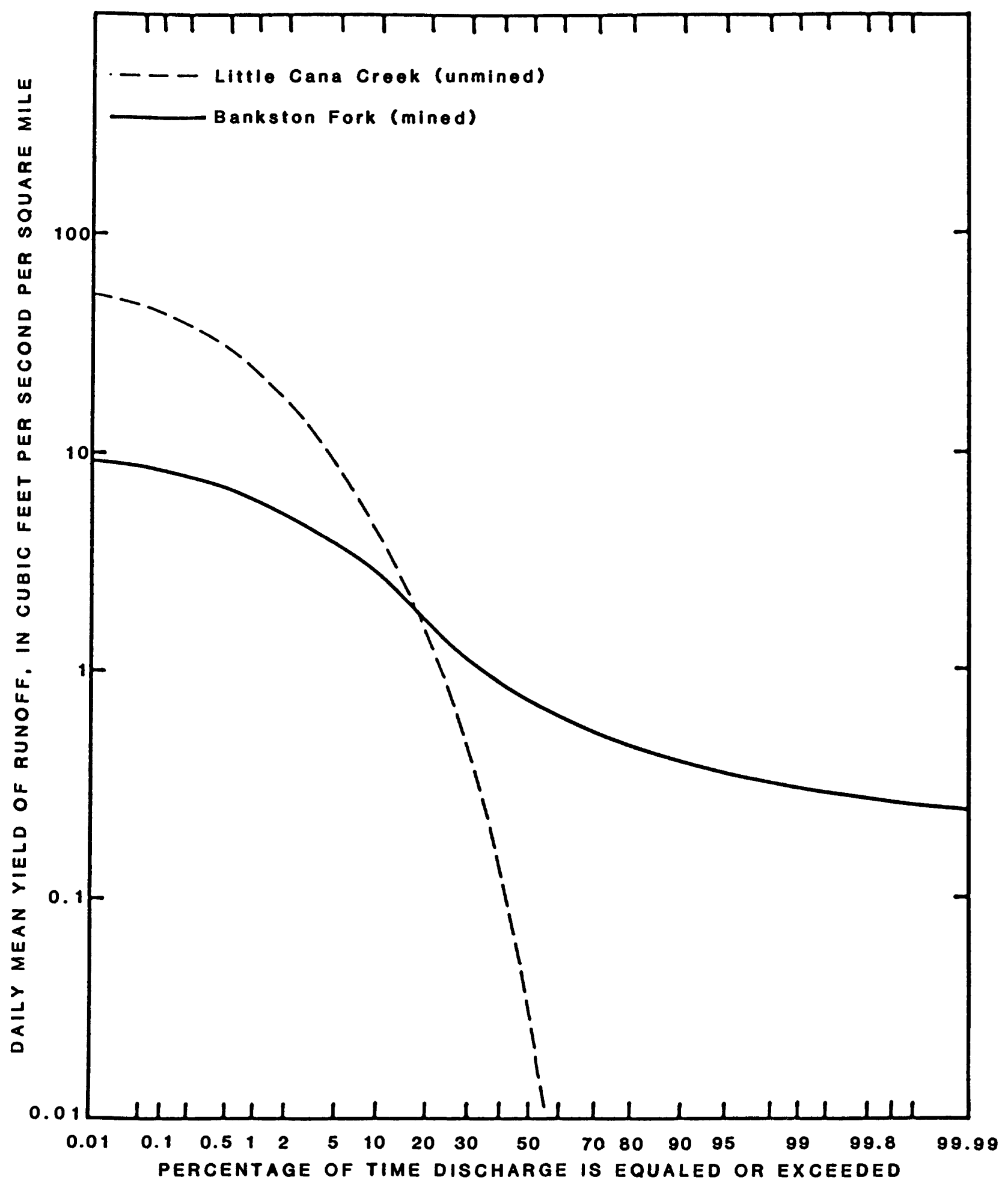

Figure 3.4-1.--Flow-duration curves for Little Cana Creek and Bankston Fork. 


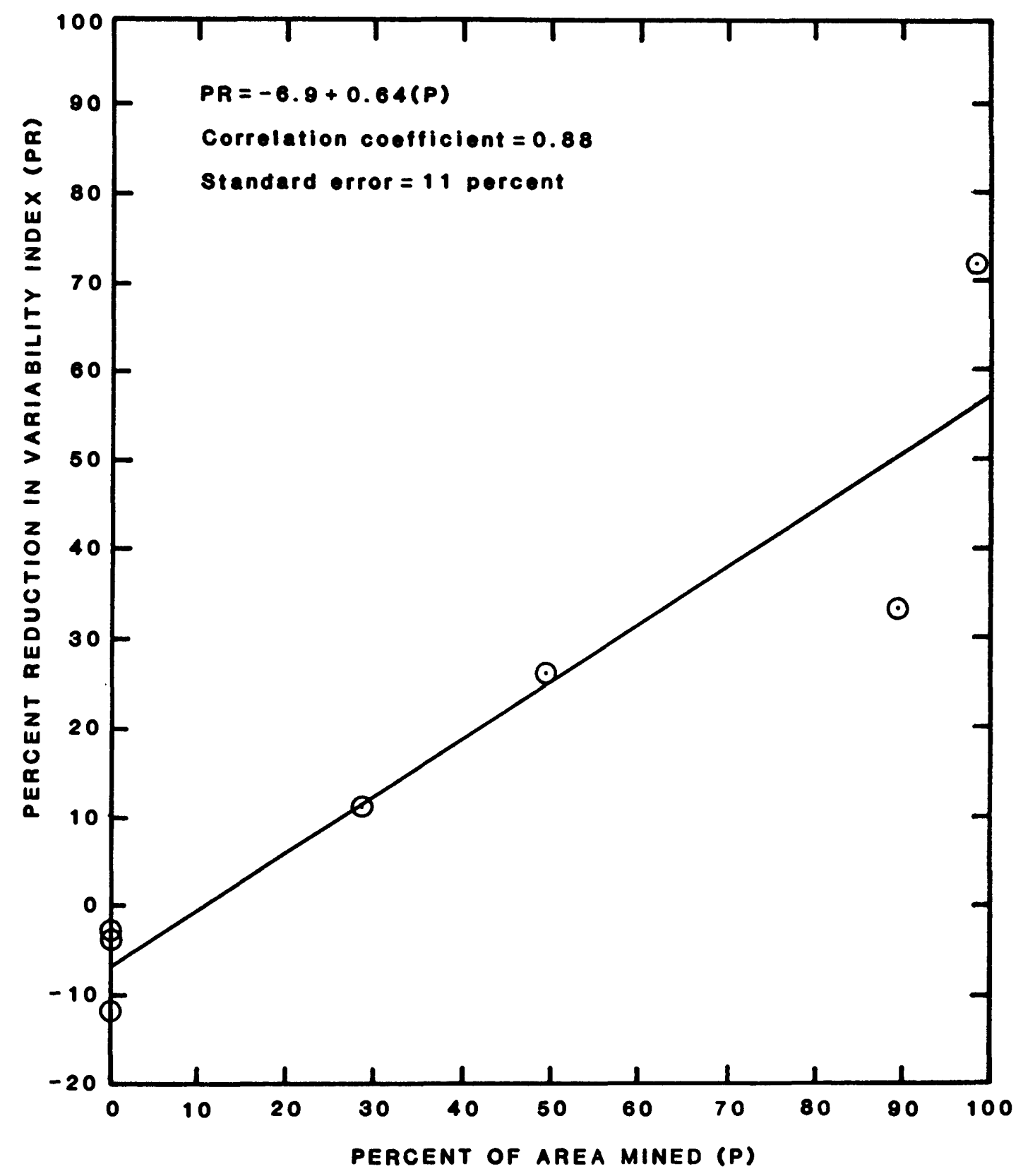

Figure 3.4-2.--Variability index comparison, Lane and Lei (1950) to Mitchell (1957) index, with percent area mined. 
Table 3.4-1 Computations of variability index for Bankston Fork

\begin{tabular}{ccccc}
\hline Percent & $\begin{array}{c}\text { Cubic } \\
\text { feet } \\
\text { per } \\
\text { square } \\
\text { mile }\end{array}$ & log. & $\begin{array}{c}\text { Departure } \\
\text { from } \\
\text { mean }\end{array}$ & $\begin{array}{c}\text { Square of } \\
\text { departure }\end{array}$ \\
\hline 5 & 4.1 & 0.61 & 0.70 & 0.49 \\
15 & 2.3 & .36 & .45 & .20 \\
25 & 1.1 & .05 & .14 & .02 \\
35 & .88 & -.06 & -.03 & .001 \\
45 & .75 & -.12 & -.03 & .001 \\
55 & .62 &.- .21 & -.11 & .012 \\
65 & .53 & -.27 & -.18 & .032 \\
75 & .44 & -.35 & -.26 & .068 \\
85 & .40 & -.40 & -.31 & .096 \\
95 & .35 & -.45 & -.36 & .130 \\
SUMS & & -.90 & & 1.05 \\
Mean of values & & & \\
in log column & -.09 & & \\
\hline
\end{tabular}


Table 3.4-2 Variability index for the seven study sites

\begin{tabular}{lcccc}
\hline \multicolumn{1}{c}{ Station } & $\begin{array}{c}\text { Percent } \\
\text { mined }\end{array}$ & $\begin{array}{c}\text { Variability } \\
\text { index }\end{array}$ & $\begin{array}{c}\text { Index from } \\
\text { Mitchell's } \\
\text { map }\end{array}$ & $\begin{array}{c}\text { Reduction } \\
\text { in } \\
\text { variability }\end{array}$ \\
\hline SOUTHERN ILLINOIS & & & & \\
Little Cana Greek & 0 & 1.29 & 1.20 & -12 \\
Bankston Fork & 99 & .34 & 1.20 & 72 \\
WESTERN ILLINOIS & & & & -4 \\
Turkey Greek & 0 & .78 & .75 & 11 \\
West Branch Big Creek & 29 & .67 & .75 & 33 \\
Slug Run & 90 & .50 & .75 & \\
SOUTHWESTERN ILLINOIS & & & .95 & -3 \\
South Branch Doza Creek & 0 & .98 & .95 & 26 \\
Doza Creek & 50 & .70 & & \\
\hline
\end{tabular}




\title{
3.0 Surface Water
}

\subsection{Synthetic Flow-Duration Curves}

\section{SYNTHETIC FLOW-DURATION CURVES CAN BE DEVELOPED FOR SURFACE-MINED AREAS}

\author{
Synthetic flow-duration curves were developed for a basin \\ that will be surface mined in the future.
}

Mitchell (1957) described a technique for developing flow-duration curves for ungaged streams. His technique is presented here, with some modifications, for the purpose of developing flow-duration curves applicable to streams in mined basins. Steps 2, 4, and 5 are modifications to his method.

(1) Find the variability index of the stream from Mitchell's map, reproduced here as figure $3.5-1$.

(2) Determine the percentage reduction in the variability index caused by surface mining with the equation developed in the previous section (fig. 3.4-2).

(3) Compute the adjusted variability index (v).

(4) Determine the average discharge $\left(Q_{A}\right)$, in cublc feet per second $\left(f t^{3} / s\right)$, by equations developed by zuehls and others (1981a, 1981b) and Fitzgerald, Peters, and Zuehls (1983):

$$
\begin{array}{ll}
\text { Southern Illinois } & -Q_{A}=A^{0.97} \\
\text { Southwestern Illinois }-Q_{A}=0.81 \mathrm{~A} \\
\text { Western Illinois } & -Q_{A}=0.72 \mathrm{~A}^{0.98}
\end{array}
$$

where $A$ is the drainage area, in square miles.

(5) Divide the average discharge $\left(Q_{A}\right)$ by the drainage area to obtain average runoff $\left(Q_{a}\right)$ in cubic feet per second per square mile $\left[\left(f t^{3} / s\right) / m t^{2}\right]$.

(6) Determine the discharge equaled or exceeded 1 percent of the time by the equation (Mitchell, 1957, p. 168):

$$
Q_{1.0}=12.06 v^{0.58} Q_{a} 0.99
$$

where $Q_{1.0}$ is the alscharge equaled or exceeded 1 percent of the time, in cubic feet per second per square mile.

(7) Determine the discharge equaled or exceeded 99 percent of the time by the equation:

$$
2_{99}=0.002 v^{-4.88} Q_{a}^{0.566}
$$


where 299 = the discharge equaled or exceeded 99 percent of the time, in cubic feet per second per square mile.

The equation in step 7 is a modification of Mitchell's (1957, p. 168) equation. Mitchell related 299 to the variability index only. However, by relating 299 to both the variability index and average runoff, the accuracy of estimating 299 was improved (lower standard error of estimate).

(8) Determine the percentage of time the average discharge is equaled or exceeded by use of the equation (Mitchell, 1957, p. 175).

$$
t_{a}=36.6-16.6 \mathrm{v}
$$

where $t_{a}=$ percentage of time the average discharge is equaled or exceeded.

Plotting instructions (fig. $3.5-2$ ):

(1) Plot antilogarithm of adjusted variability index at an abscissa of 15.87 percent (probability scale). Identify it as point A.

(2) Plot $1.0\left(\mathrm{ft}^{3} / \mathrm{s}\right) / \mathrm{mi}^{2}$ as ordinate at abscissa of 50.0 percent. Identify it as point $B$.

(3) Plot 21.0 at abscissa of 1.0 percent. Identify it as point $C$.

(4) Multiply the value of 21.0 by 2 and plot the product at abscissa of 0.1 percent. Identify it as point $D$.

(5) Plot 299 at abscissa of 99.0 percent. Identify it as point $\mathrm{E}$.

(6) Plot average runoff as ordinate at $t_{a}$ as abscissa. Identify it as point $F$.

(7) Through point $F$; draw a straight line parallel to a line through points $A$ and $B ;$ extend this line from near 5 percent abscissa to near 95 percent abscissa.

(8) Through point $C$ and through or near to point $D$, draw a curve to merge with the straight line through point $F$.

(9) Through point E draw another curve to merge with the straight line through point $F$.

Figure 3.5-2 shows synthetic flow-duration curves developed for Brushy Creek near Harco (southern Illinois). Surface mining has just begun in this basin, and the intent is to mine the entire watershed $\left(13.3 \mathrm{mi}^{2}\right)$. Flowduration curves are shown for conditions of no mining and for different percentages of mining. An example computation is given for 100 percent of the basin mined. The number to the left refers to the step explained above. 
1. From Mitchell's map (fig. 3.5-1), variability index $=1.25$.

2. From the equation (fig. $3.4-2$ ), percent reduction $=-6.9+.64(100)=$ 57 percent.

3. Adjusted variability index $=0.43(1.25)=0.54$.

4. Fran the equation for southern Illinois, $Q_{A}=A^{0.97}$, average discharge $=12.3 \mathrm{ft}^{3} / \mathrm{s}$.

5. $Q_{a}=12.3 / 13.3=0.92\left(\mathrm{ft}^{3} / \mathrm{s}\right) / \mathrm{mi}^{2}$.

6. $Q_{1.0}=12.06\left(0.54^{0.58}\right)\left(0.92^{0.99}\right)=7.8\left(\mathrm{ft}^{3} / \mathrm{s}\right) / \mathrm{mi}^{2}$.

7. $l_{99}=0.002\left(0.54^{-4.88}\right)\left(0.92^{0.566}\right)=0.04\left(\mathrm{ft}^{3} / \mathrm{s}\right) / \mathrm{mi}^{2}$.

8. $t_{a}=36.6-16.6(0.54)=27.6$ percent.

Plotting points

1. Point $A=$ antilogarithm $(0.55)=3.5$ at 15.87 percent.

2. Point $B=1.0\left(\mathrm{ft}^{3} / \mathrm{s}\right) / \mathrm{mi}^{2}$ at 50.0 percent.

3. Point $c=Q_{1.0}=7.8\left(\mathrm{ft}^{3} / \mathrm{s}\right) / \mathrm{mi}^{2}$ at 1.0 percent.

4. Point $D=2\left(Q_{1} .0\right)=15.8\left(\mathrm{ft}^{3} / \mathrm{s}\right) / \mathrm{mi}^{2}$ at 0.1 percent.

5. Point $E=899=0.04\left(\mathrm{ft}^{3} / \mathrm{s}\right) / \mathrm{mi}^{2}$ at 99 percent.

6. Point $F=Q_{a}$ at $t_{a}=0.92\left(\mathrm{ft}^{3} / \mathrm{s}\right) / \mathrm{mi}^{2}$ at 27.6 percent.

The error in developing a synthetic duration curve by the above method can be large. This is due to the use of a tentative relationship (fig. 3.4-2) based on limited data and the errors in estimating the variability index, average discharge, $Q_{1}$, and $Q_{99}$. 


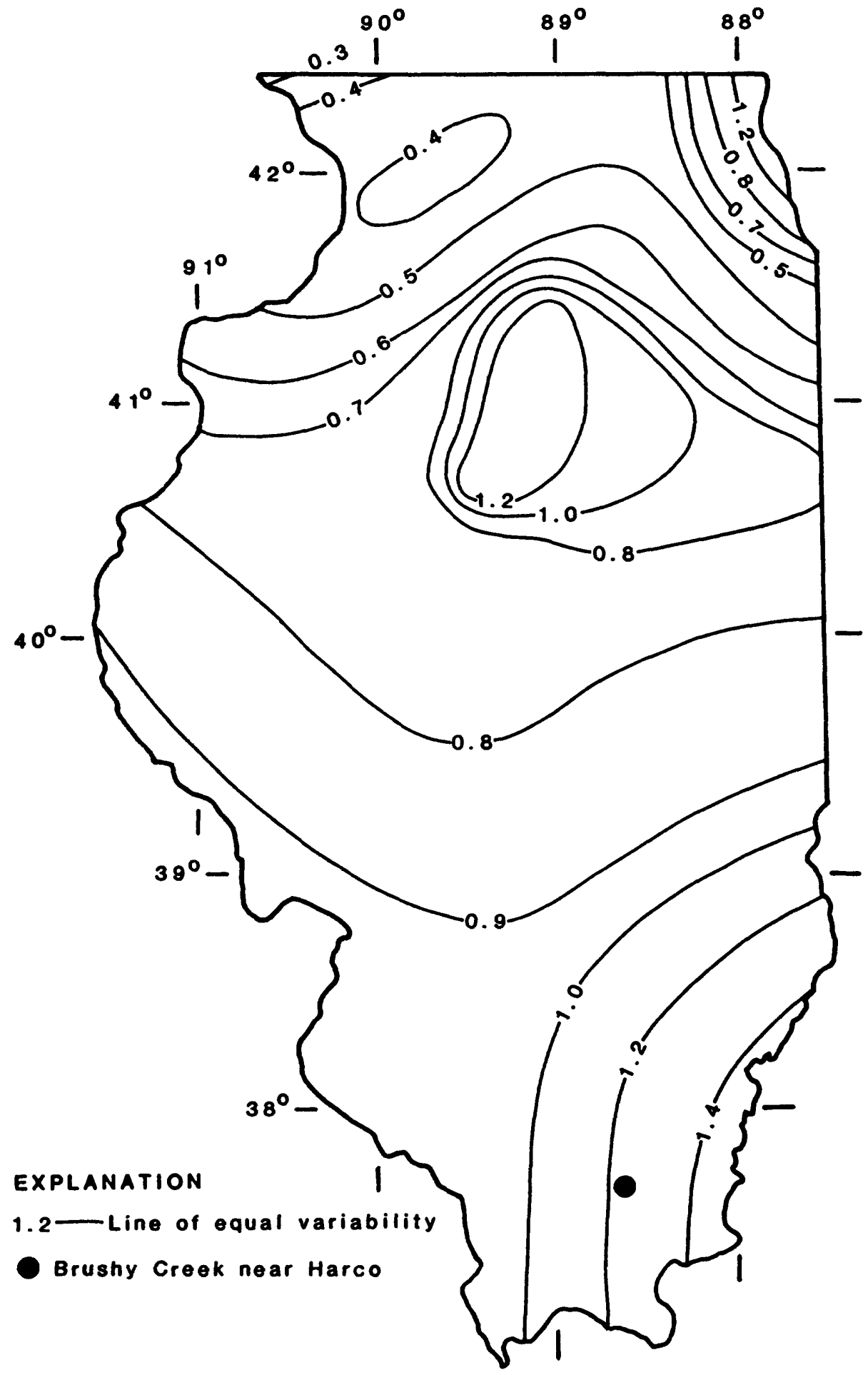

Figure 3.5-1.--Variability index values adapted from Mitchell, 1957, p. 165. 


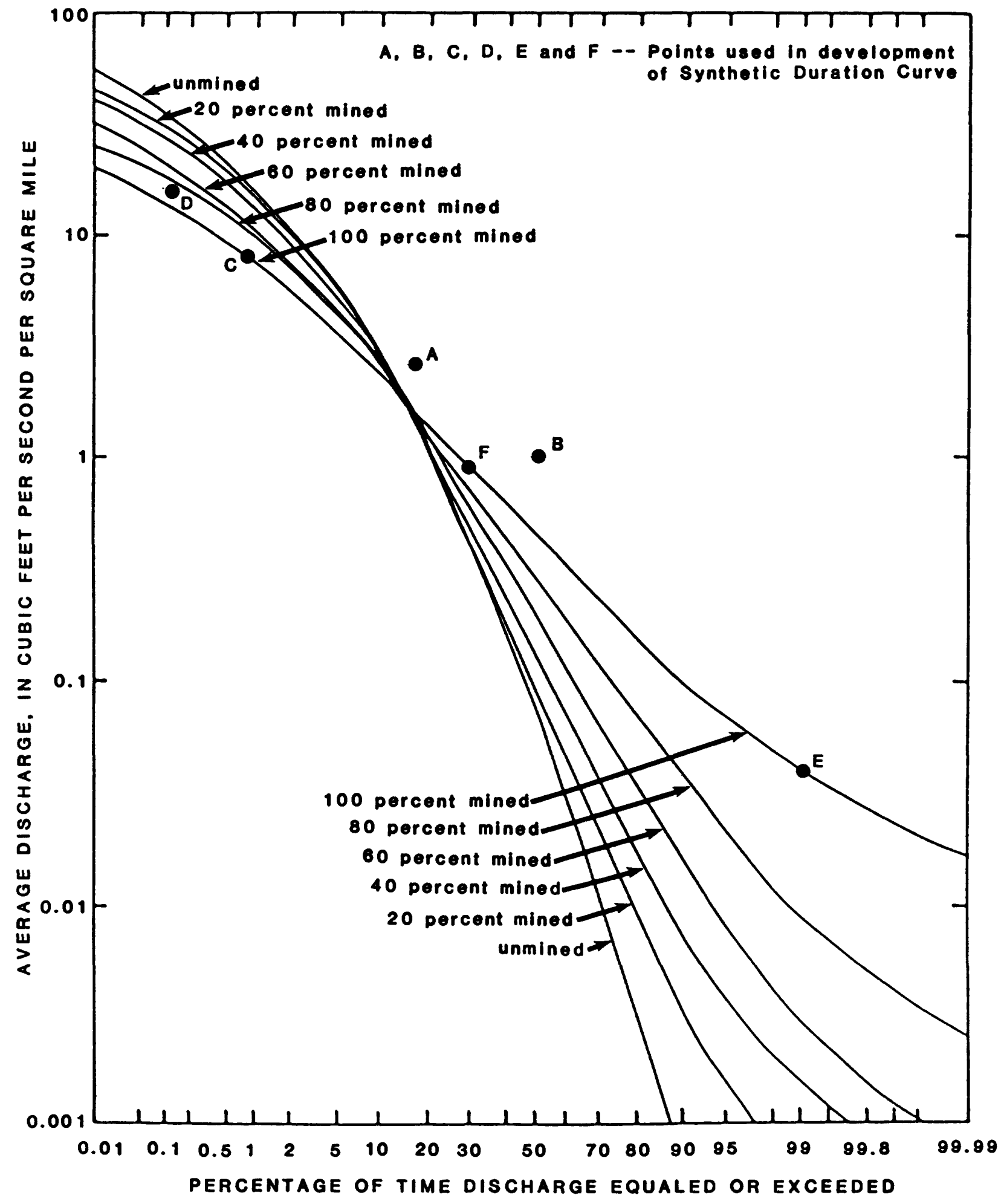

Figure 3.5-2.--Synthetic duration curves for Brushy Creek near Harco for different stages of mining. 


\subsection{Surface Water}

3.6 Conclusions

Several conclusions may be drawn from the analyses of surface-water data collected at the seven study sites.

(1) Precipltation is fairly uniform among the basins. Unmined basins, which are primarily farmland, have higher runoff during the spring high-flow periods and lower runoff curing the summer and fall low-flow perlods than mined basins.

(2) Streams draining areas that have undergone surface mining have lower variability indexes. The percentage reduction in the variability index is related to the percentage of the drainage basin mined.

(3) Synthetic flow-duration curves may be prepared for ungaged streams by using Mitchell's (1957) technique. Mitchell's variability index can be adjusted on the besis of percent mined land in order to predict flow-duration curves for ungaged streams in basins intended for surface mining.

(4) For a given storm, increased storage resulting from surface mining reduces storm runoff and peak discharges. Bquations were developed that relate storm-runoff volume and peak discharges to climatologic data and basin characteristics. 
4.0 Quality of Surface Water

4.1 Water-Quality Characteristics

SURFACE MINING INCREASES CHEMICAL AND PHYSICAL WEATHERING

Chemical and physical weathering are increased as a result of
surface mining. Streams draining mined areas have higher
concentrations of dissolved constituents than streams
draining unmined areas.

Dissolved constituents in runoff are derived from precipitation and chemical weathering. In the weathering process, air-water-mineral reactions contribute solutes to runoff and to ground-water recharge.

The geologic logs in figures 2.1-1, 2.2-1, 2.3-1 show that the HarrisburgSpringfield (No. 5) or Herrin (No. 6) coal member is overlain by a black shale, locally known as the Anna Shale Member. This shale ranges from 1 to 4 feet in thickness and has an average thickness of less than 2 feet. The shale contains significant quantities of the iron sulfide minerals, pyrite and marcasite. Although both minerals have the same ratio of sulfur to iron, the structural properties cause marcasite to be less stable and more easily decomposed than pyrite.

During surface mining, pyrite and marcasite are brought to the surface and subjected to weathering. A large amount of acid, in the form of sulfuric acid $\left(\mathrm{H}_{2} \mathrm{SO}_{4}\right)$, can be caused by weathering. However, because limestone overlies the Anna Shale, mine drainage may be neutralized before it is discharged to streams. Calcium, magnesium, sulfate, and bicarbonate go into solution when limestone or dolomite reacts with sulfuric acid in the mine drainage. As a result waters draining surface-mined basins tend to have high concentrations of sulfate, calcium, magnesium, and bicarbonate.

A common way to classify water is by its predominant cations and anions. Concentrations in milligrams per liter are converted into milliequivalents per liter, thus making unit concentrations of all ions chemically equivalent. This was done for selected chemical analyses of water from six sites (fig. 4.1-1).

Two analyses were selected for each site, one representing a high discharge and one representing a low discharge. The analyses are presented as bar graphs, the lengths of the bars being proportional to the sum of milliequivalents of anions or cations. Each bar is split to represent cations and anions and divided into segments showing the concentrations of individual ions.

The bar graphs illustrate that the mined areas have higher concentrations of dissolved constituents. The dissolved constituents are diluted at high flows; however, the dilution seems less in the mined areas than in the unmined areas. 


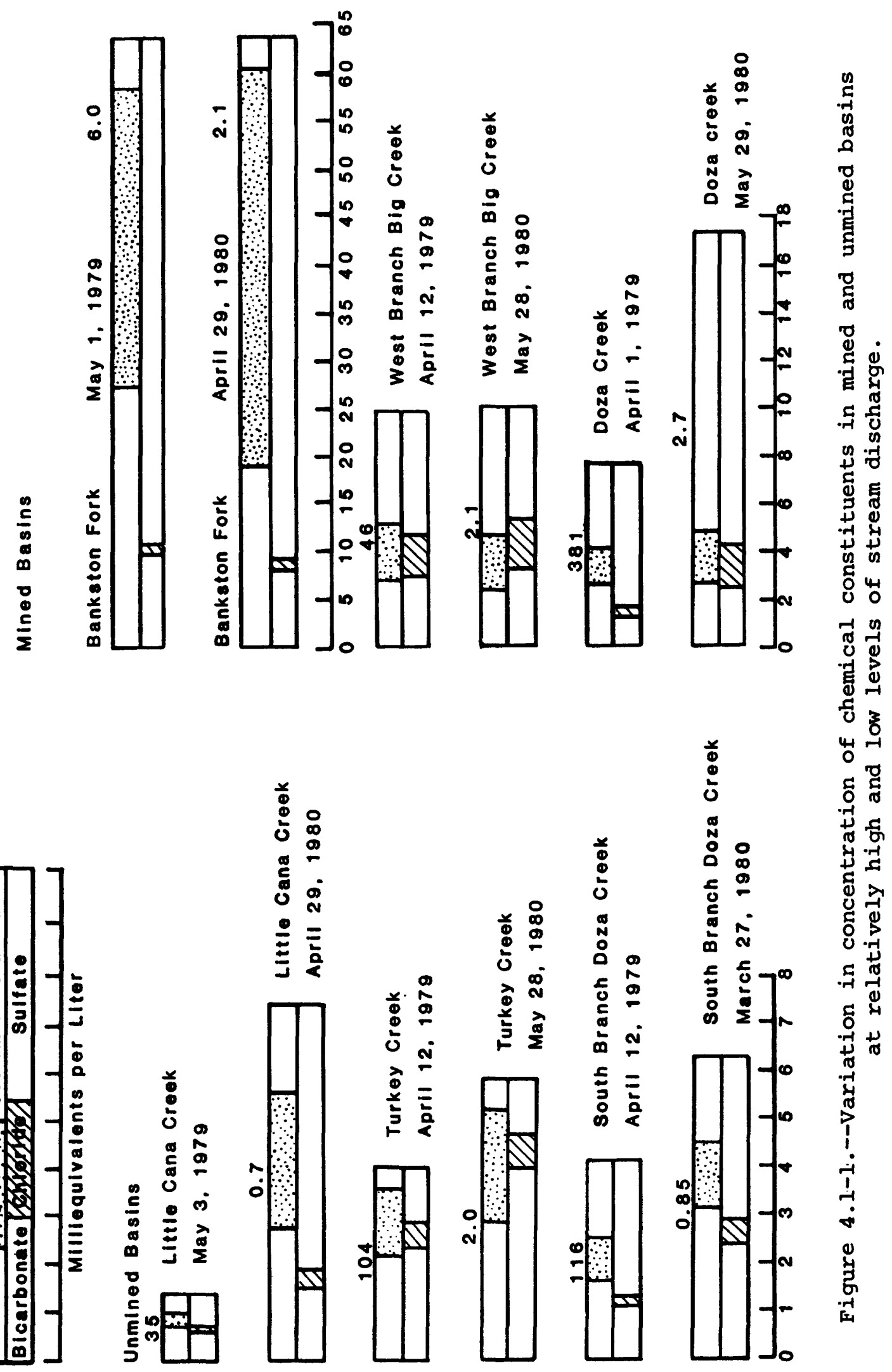


4.0 Quality of Surface Water

4.2 Specific Conductance as Indicator of Dissolved Solids

\title{
DISSOLVED-SOLIDS CONCENTRATIONS HIGHER IN MINED AREAS
}

\begin{abstract}
Annual dissolved-solids loads were determined from measurements of specific conductance and discharge and by relating dissolved solids to discharge. Mined areas had higher yields than unmined areas and regional relations showed the high dissolved-solids loads in the saline and Big Muddy River basins.
\end{abstract}

Specific conductance, an indirect measure of dissolved solids, was recorded at six sites for 2 years, beginning in 1978, and at slug Run since July 1975. Figure 4.2-1 shows the relation between dissolved-solids concentrations and specific conductances for Doza Creek. The two characteristics are highly correlated at this site and also at the other six sites.

The relation between dissolved solids and specific conductance for each station was developed from periodic samples taken at various discharges. From these relations and records of daily specific conductance and daily discharge, dally dissolved-solids loads for each station were determined.

Two years of dally loads in tons for each of the six sites were used to compute mean annual dissolved-solids yields in tons per square mile. Four years of data for the slug Run basin were used to compute its mean yield. Mean dissolved-solids yields for 1978-79 water years are:

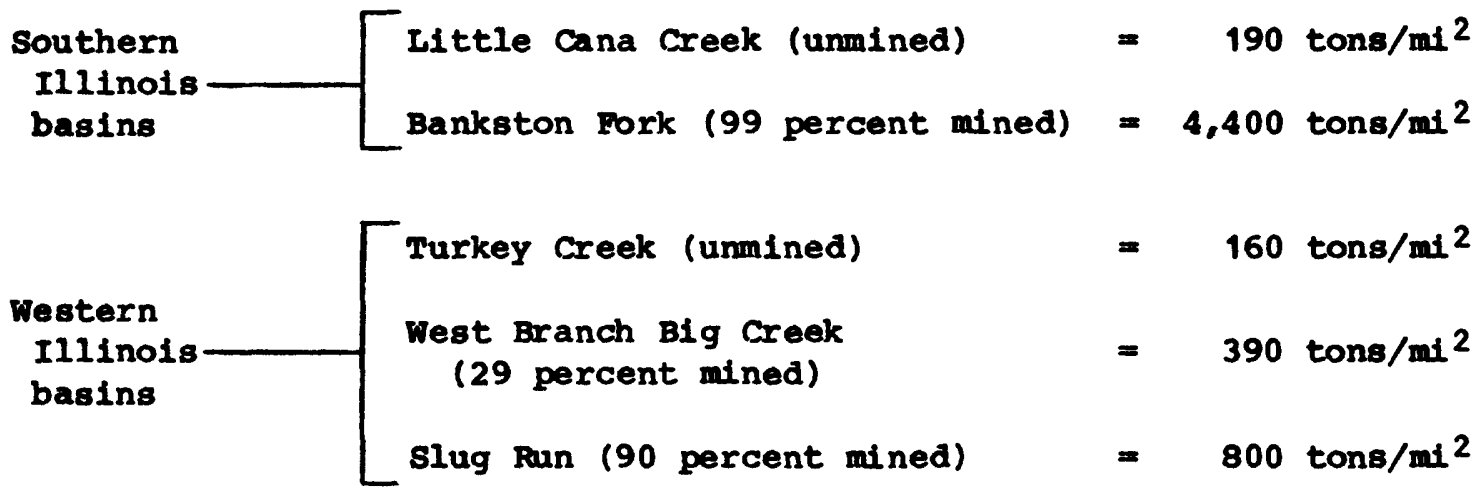

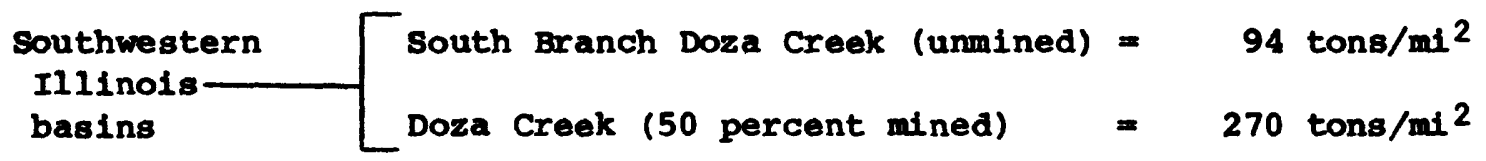

Dissolved-solids yields were also calculated for two sites where data were scant, Big Muddy River at Murphysboro and South Fork saline River near Carrier Mills. Neither of these sites has continuous records of specific conductance, but both have continuous discharge records. The annual dissolved-solids yields were computed by the duration-curve technique (Searcy, 1959). This technique 
depends on the correlation of the dissolved-solids concentration with stream discharge and the availability of flow-duration curves. An example of this technique is shown in toler (1982, p. 10-13). The mean annual dissolved-solids yields for these two stations were:

$$
\begin{array}{ll}
\text { South Fork Saline River }(6.7 \text { percent mined }) & =414 \text { tons } / \mathrm{mi}^{2} \\
\text { Big Mudy River }(2.4 \text { percent mined) } & =172 \text { tons } / \mathrm{mi}^{2}
\end{array}
$$

Dissolved-solids yields were plotted against the percentage of drainage area disturbed by surface mining. Two graphs, one for basins in the western part of Illinois (fig. 4.2-2) and one for basins in the southern part of Illinois (fig. 4.2-3), indicate correlation between yields and percentage of area mined. Dissolved-solids yields from the basins in the southern part of Illinois were higher than yields from the basins in the western part.

A method to estimate mean annual dissolved-solids loads for streams in the western and southern parts of Illinols is as follows:

(1) From figure 4.2-2 or 4.2-3, determine the mean annual dissolved-solids yield, in tons per square mile, using the percentage of drainage area surface mined.

(2) Compute the mean annual dissolved-solids loads, in tons, by multiplying the mean annual dissolved-solids yields by the drainage area. 


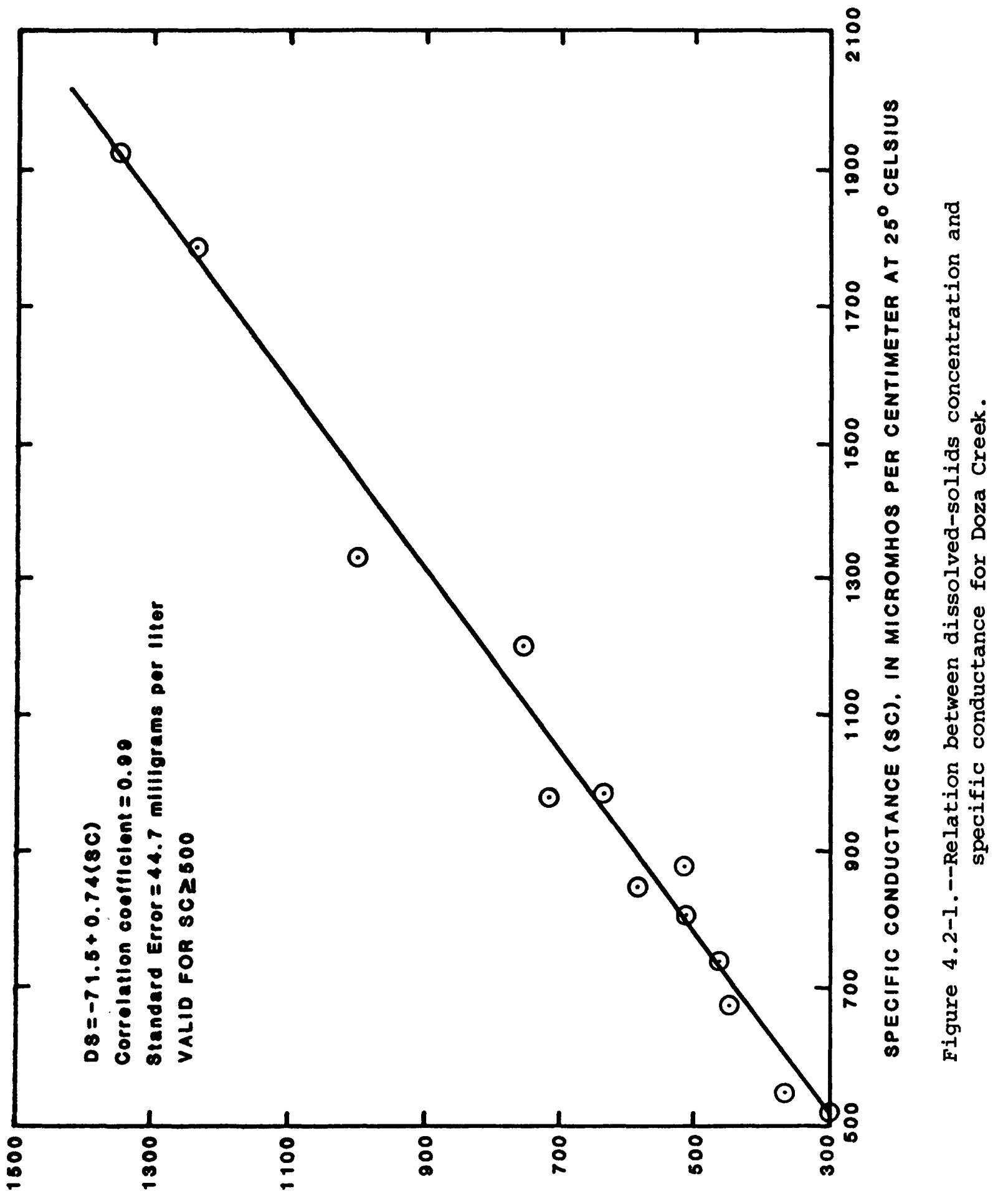

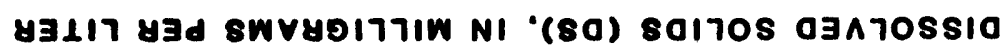




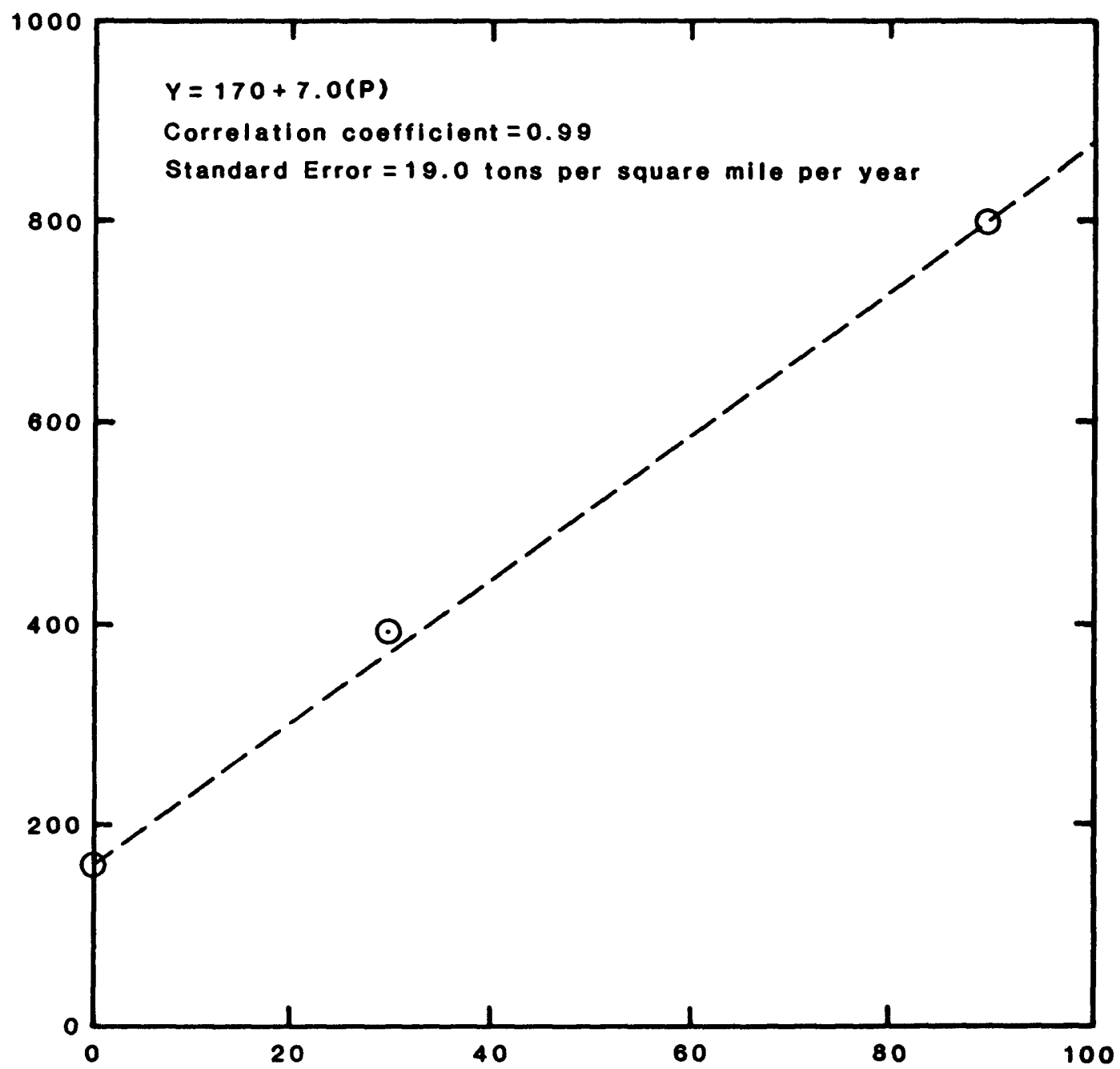

AREA OF SURFACE MINES (P) AS A PERCENTAGE OF TOTAL DRAINAGE AREA

Figure 4.2-2.--Relation between dissolved-solids yield and percentage of the area surface mined for three western Illinois basins. 


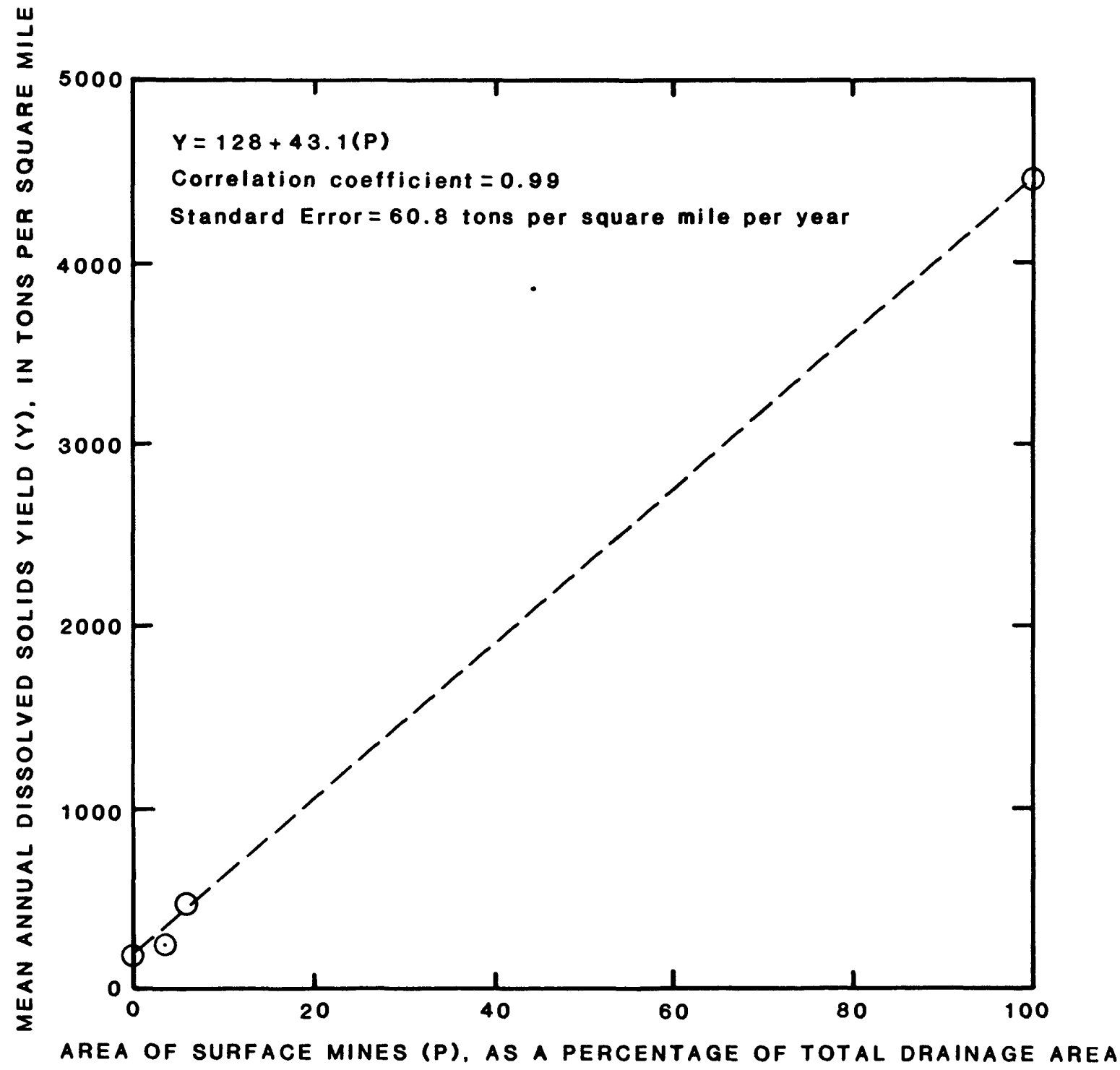

Figure 4.2-3.--Relation between dissolved-solids yield and percentage of the area surface mined for four southern Illinois basins. 
4.0 Quality of Surface Water

4.3 Sulfate

\title{
SURFACE MINING INCREASES SULFATE YIELDS
}

\author{
Annual sulfate yields were determined by relating sulfate \\ concentrations to dissolved-solids concentrations. \\ Regional relations show the largest sulfate yields \\ are in the Saline-Big Muddy River basins.
}

Sulfate is a major solute produced in the formation of acid mine water. Although other constituents may subsequently be dissolved or precipitated as a result of neutralization by acidic waters, the sulfate introduced through mine drainage remains in solution and can be used as an indicator of mine drainage.

For all seven sites, a high degree of correlation exists between sulfate and dissolved-solids concentrations, as shown in figure 4.3-1 for south Branch Doza Creek. Annual sulfate loads were calculated by using the equation relating sulfate and dissolved solids and the equations developed in section 4.2. The annual sulfate yields for the seven sites are:

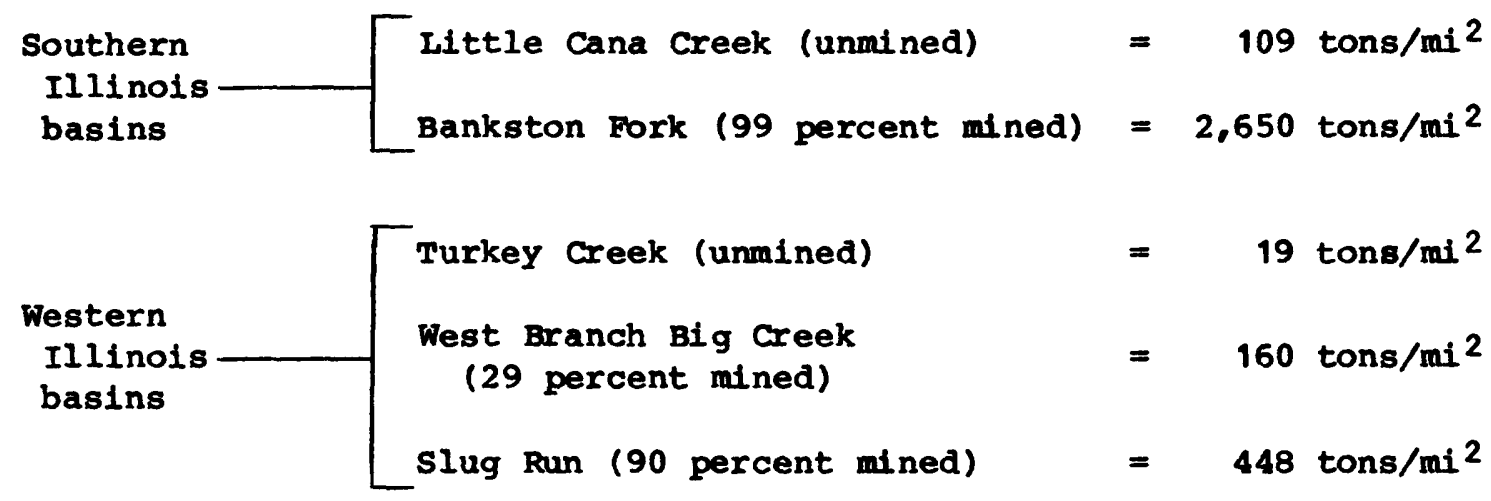

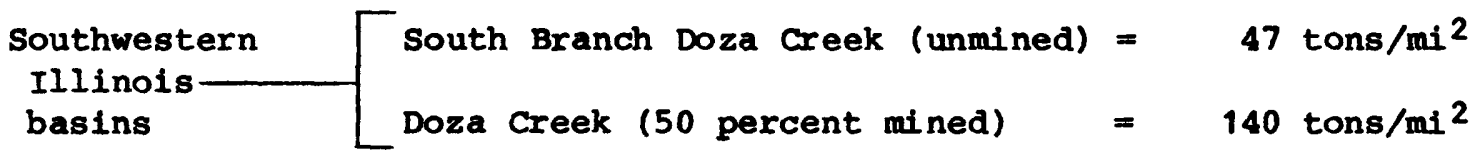

Sulfate yields were plotted as a function of the percentage of drainage area that has been surface mined. Separate relations were developed for the sites in western and southern parts of Illinois (figs. 4.3-2 and 4.3-3). Toler (1982) had previously established such a relation for sites in the southern part of Illinois. Data for Bankston Fork (99 percent mined, fig. 4.3-3) were used to extend Toler's relation.

A comparison of figures $4 \cdot 3-2$ and 4.3-3 shows that more sulfate is produced in the basins studied in the southern part of Illinois than in basins studied in other parts of Illinols. The least amount of sulfate was produced in basins studied in the southwestern part of Illinois (Raskaskia River basin). 


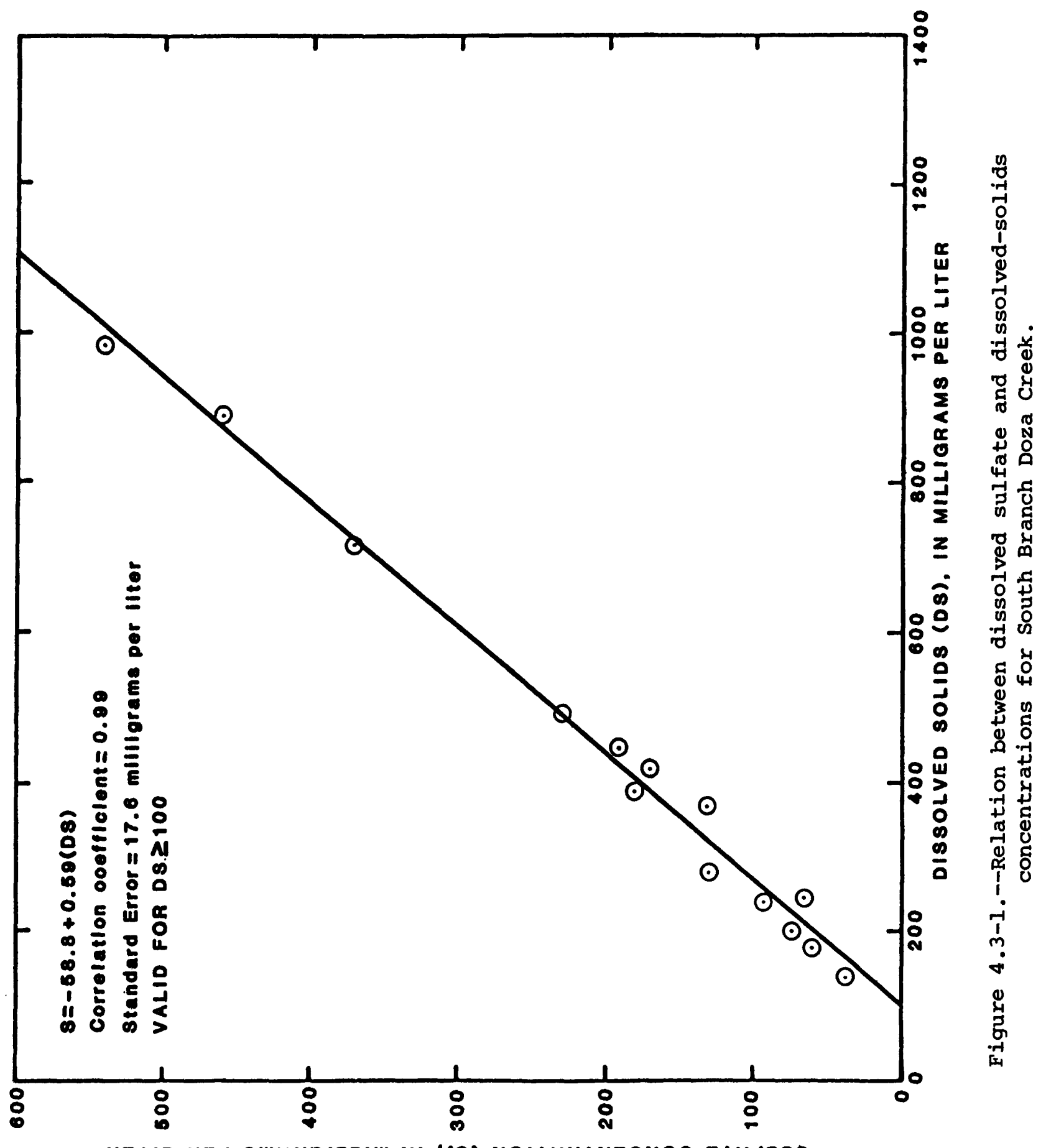

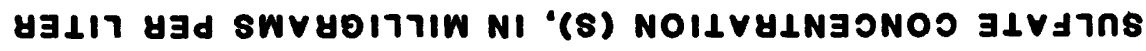




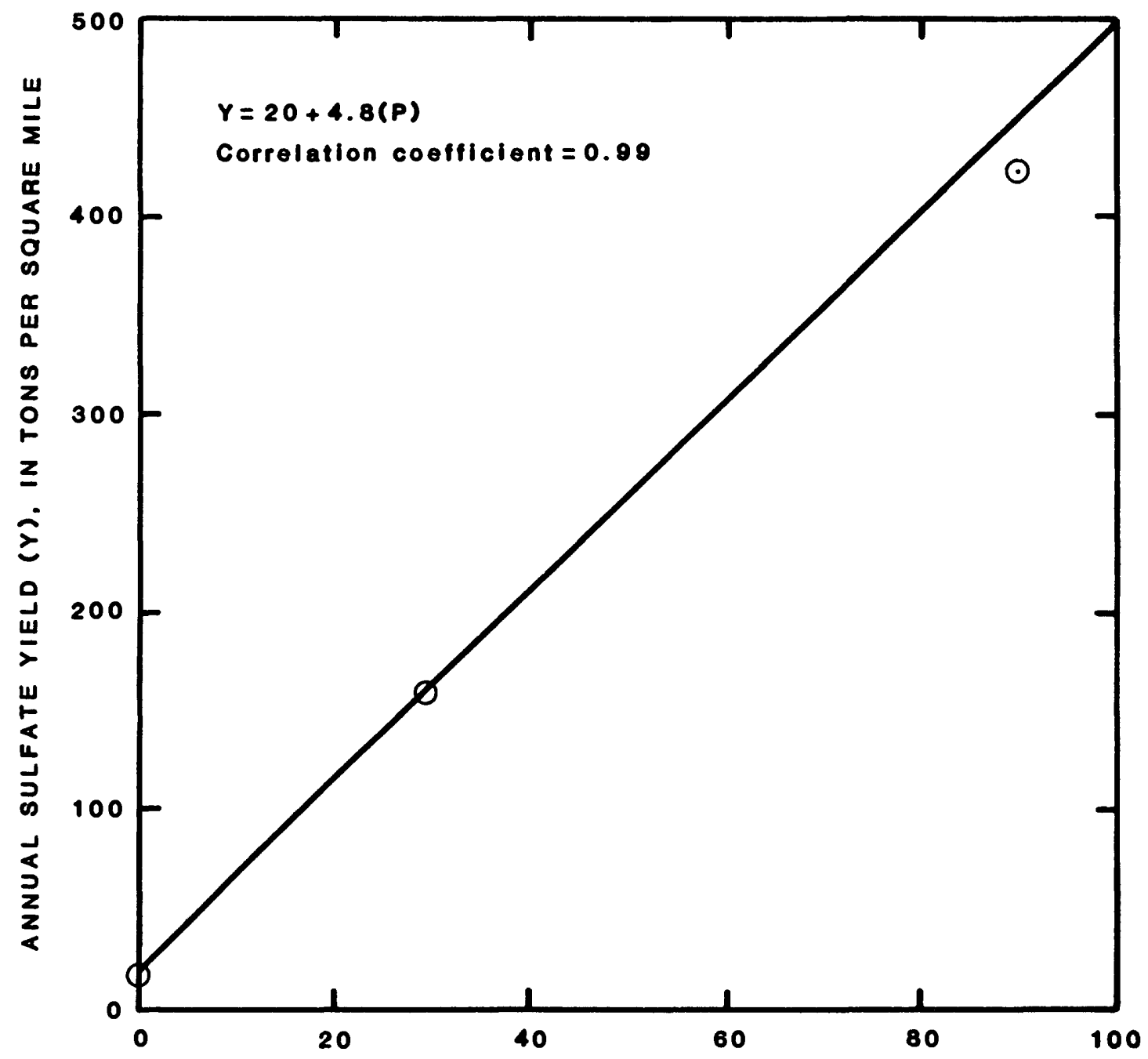

area of surface mines (P). As a percentage of total drainage area

Figure 4.3-2.--Relation between dissolved sulfate yield and percent area surface mined for three

western Illinois basins. 


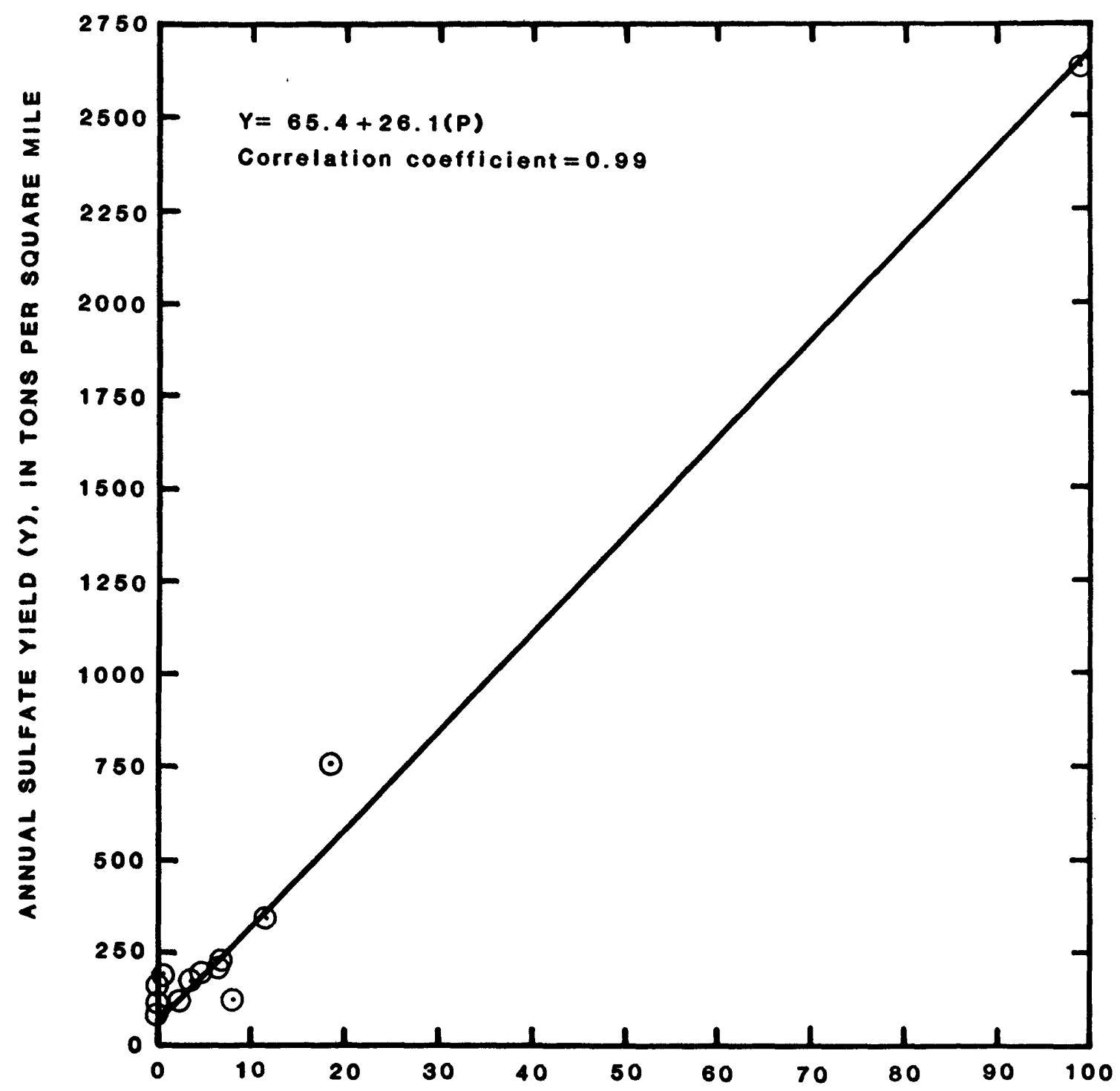

AREA OF SURFACE MINES (P). AS A PERCENTAGE OF TOTAL DRAINAGE AREA

Figure 4.3-3.--Relation between dissolved sulfate yield and percent area surface mined for 13 southern Illinois basins. 


\title{
4.0 Quality of Surface Water
}

4.4 Calcium

\section{SURFACE-MINED BASINS HAVE HIGH CALCIUM YIELDS}

\author{
Annual calcium yields were determined by relating calcium to \\ dissolved solids. Regional relations show the highest \\ calcium yields in the Saline-Big Muddy River basins.
}

Limestone (calcium carbonate), in contact with acid mine drainage, will neutralize the acid produced by the oxidation of pyrite. If limestone is present in sufficient quantities, calcium can become a major constituent in waters draining surface-mined areas.

Calcium concentrations are plotted as a function of dissolved-solids concentrations for South Branch Doza Creek (fig. 4.4-1). Annual calcium yields for the seven sites were computed to be:

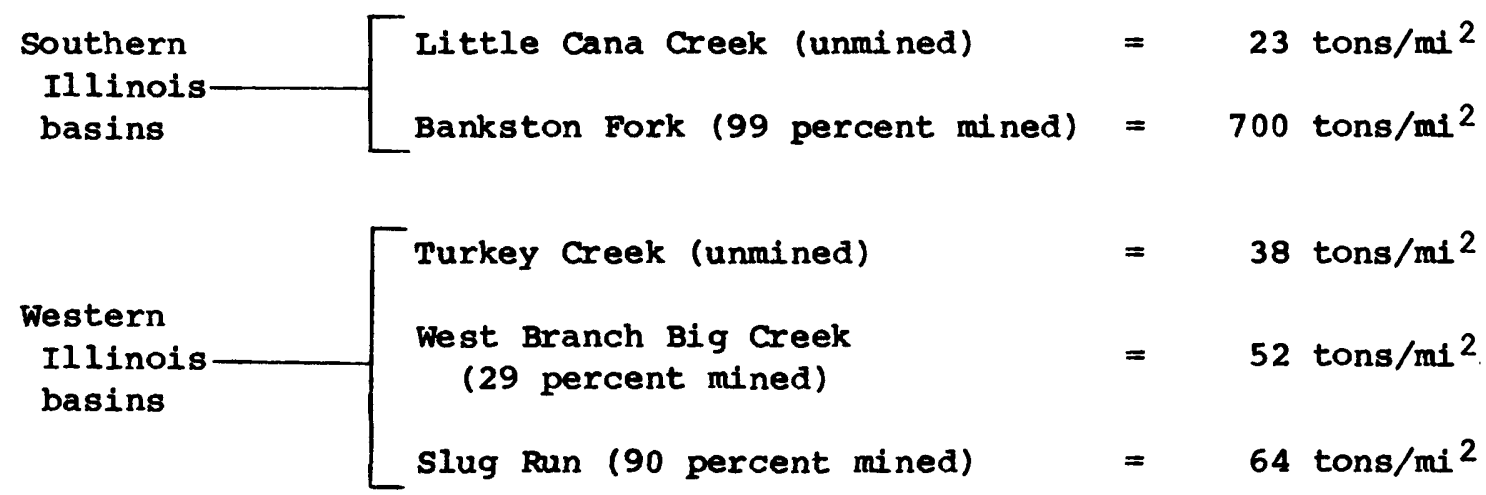

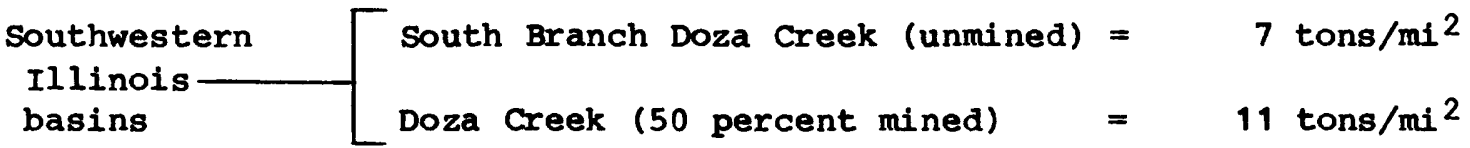

Annual calcium ylelds were also calculated for Big Muddy River at Murphysboro and South Fork Saline River near Carrier Mills and are:

Big Muddy River (2.4 percent mined) $=24$ tons $/ \mathrm{mi}^{2}$; South Fork Saline River $(6.7$ percent mined $)=55$ tons $/ \mathrm{mi}^{2}$.

Annual calcium yields were plotted as a function of percentage of surfacemined area for sites in western and southern parts of Illinols. Figures 4.4-2 and 4.4-3 show that more calcium is produced as a result of surface mining at sites in the southern part of the state than at sites in the western part.

Comparing the calcium yields from Doza Creek and South Branch Doza Creek to values in figures $4.4-2$ and $4.4-3$ indlcates that sites in the southwestern part of Illinois produce the lowest calcium ylelds of the sites studied. 


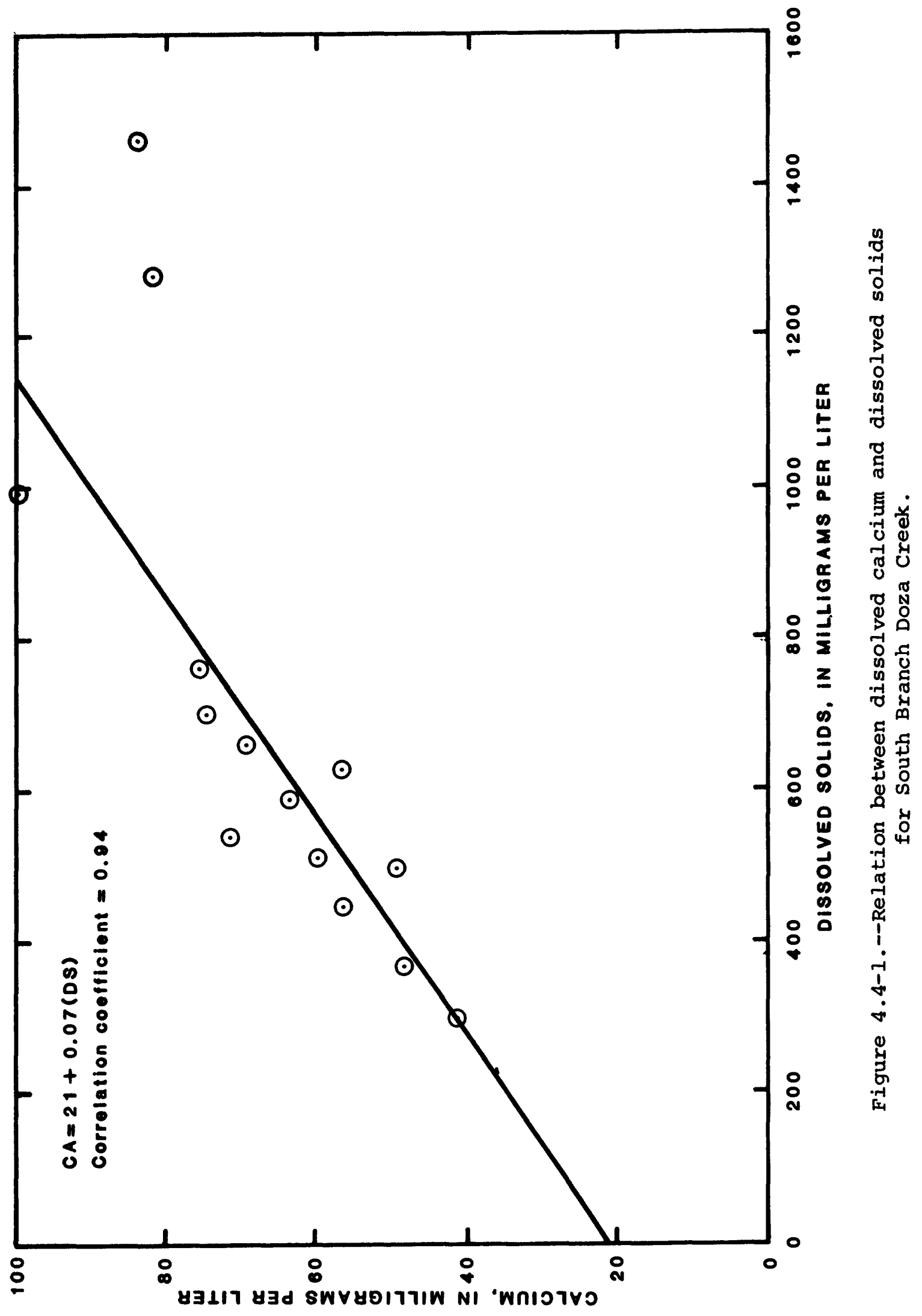




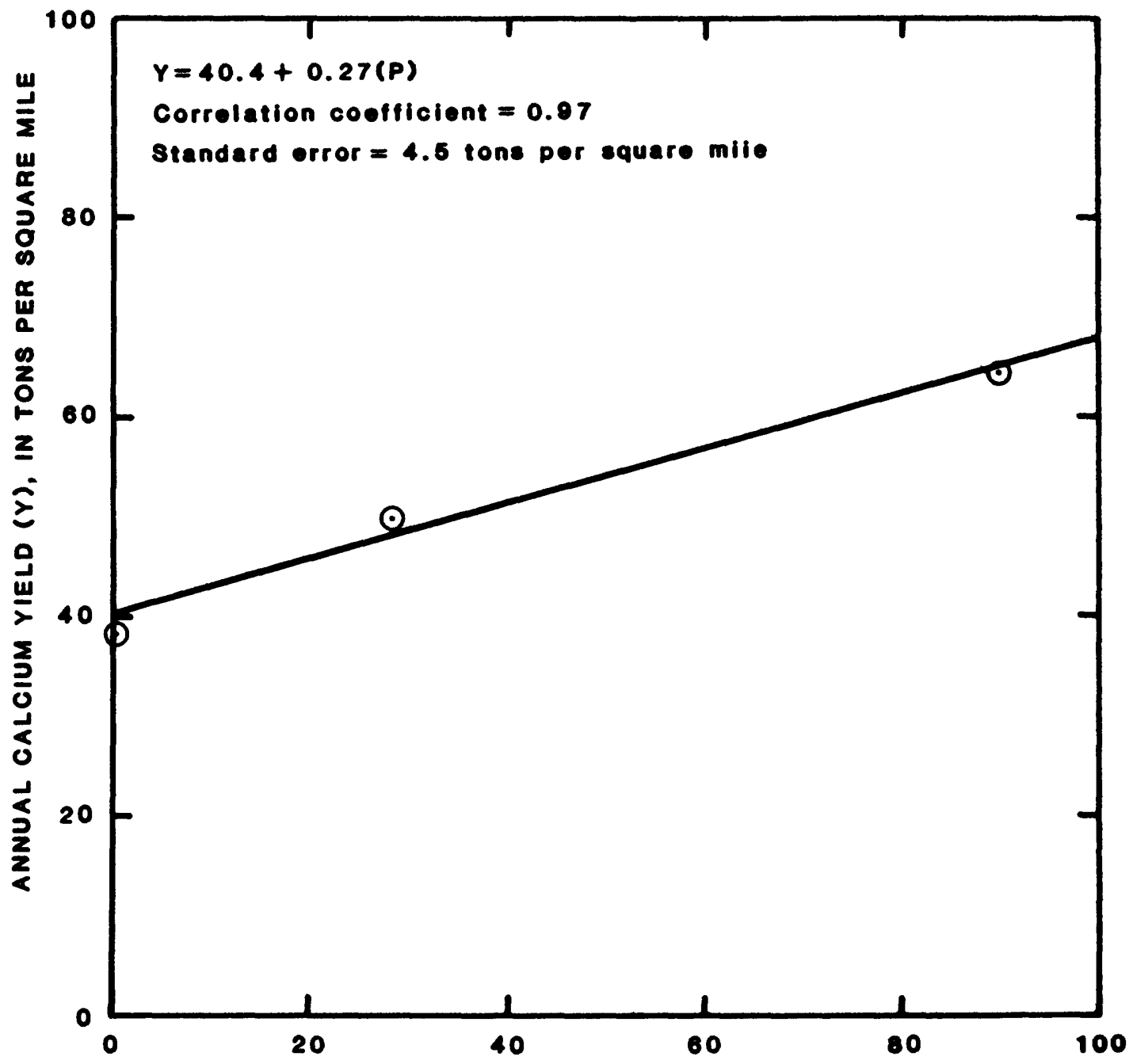

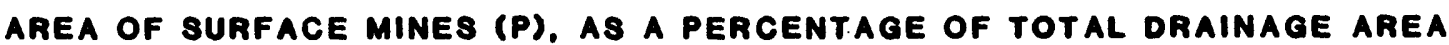

Figure 4.4-2.--Relation between dissolved calcium yield and percent area surface mined for western Illinois basins. 


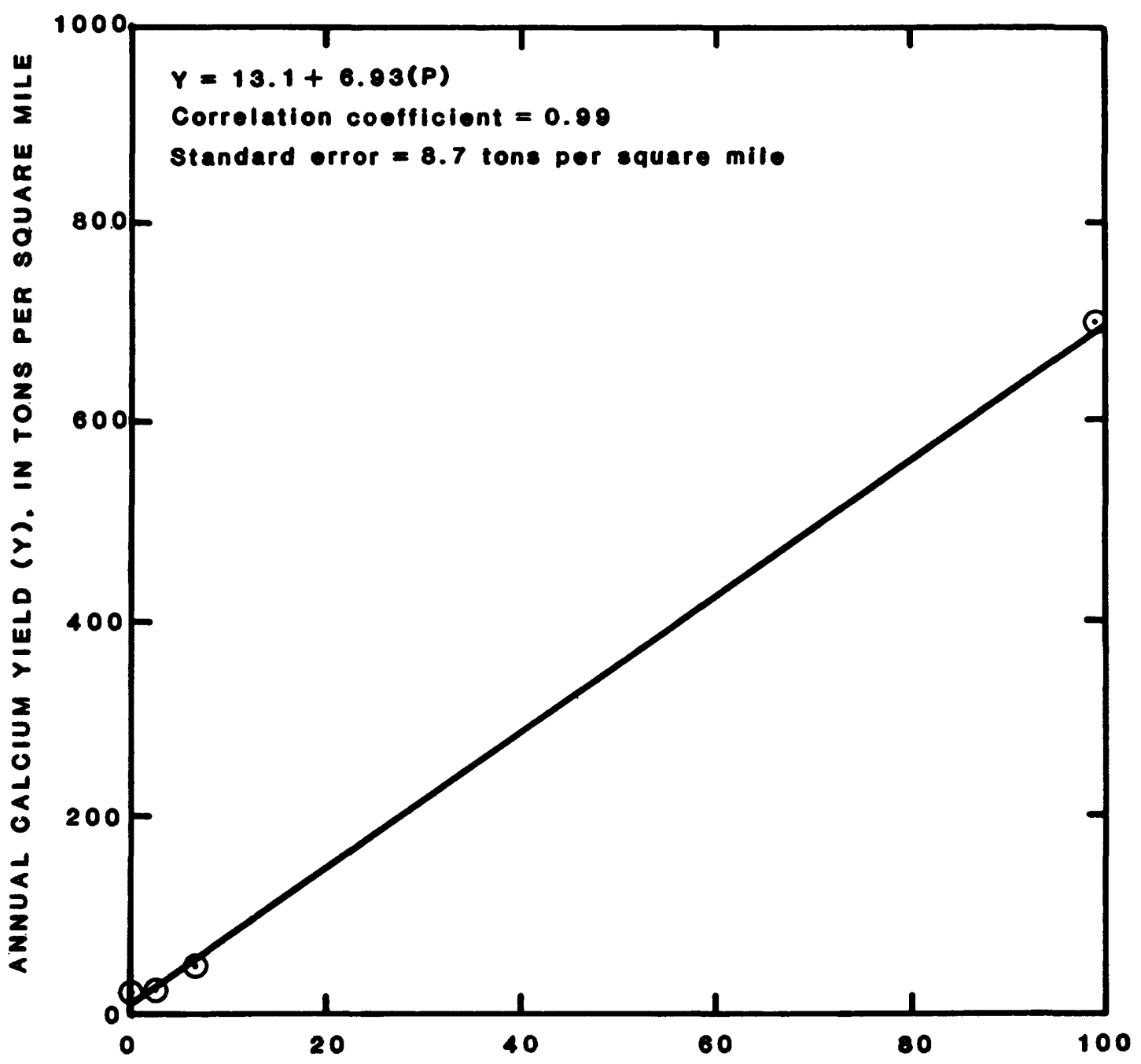

AREA Of sURface mines (P). AS a percentage of total drainage area

Figure 4.4-3.--Relation between dissolved calcium yield and percent area surface mined for southern Illinois basins. 


\title{
4.0 Quality of Surface Water
}

4.5 Water Temperature

\section{SURFACE MINING AFFECTS WATER TEMPERATURE}

\author{
Harmonic analysis of data from seven stations indicates higher \\ mean temperatures and lower amplitudes of the temperature \\ curve for streams draining surface-mined basins than \\ unmined basins. However, these differences are \\ not apparent in streams draining large basins.
}

The annual variation of stream temperature has been shown (Ward, 1963; Collings, 1969; Steele and Gilroy, 1972) to be approximated by a simple harmonic function of the form:

$$
T=M+A[\sin (0.0172 x+C)]
$$

where $T=$ stream temperature, in degrees celsius, on day $x$, as $x$ varies from 1 to 366 (October 1 as day 1);

$M=$ mean annual stream temperature, in degrees celsius;

$A=$ amplitude of the annual stream-temperature curve, in degrees celsius;

$C=$ phase coefficient of the annual cycle, in radians.

A generalized harmonic curve illustrating these relations is shown in figure 4.5-1.

The generalized harmonic curve was fitted to the daily stream-temperature data from each site. Water temperature data from zogorski and Riesler (1976) plotted in figure 4.5-1, show the harmonic character of the seasonal temperature changes. Harmonic coefficients $M, A$, and $C$ were calculated for each site and are shown in table 4.5-1. In addition to the harmonic coefficients, the standard error of estimate of a daily temperature value and the percentage of the varlation in daily temperature values that is accounted for by the harmonic function also are presented.

Results of the harmonic analyses of data from the seven sites show that the harmonic mean is higher for mined basins than for unmined basins and that amplitude $A$ is lower for mined basins. However, these relationships were noted only in streams that have relatively small drainage areas; for streams draining large watersheds, no differences were apparent. Table 4.5-2 shows the results of harmonic analyses of records from long-term gaging stations. 


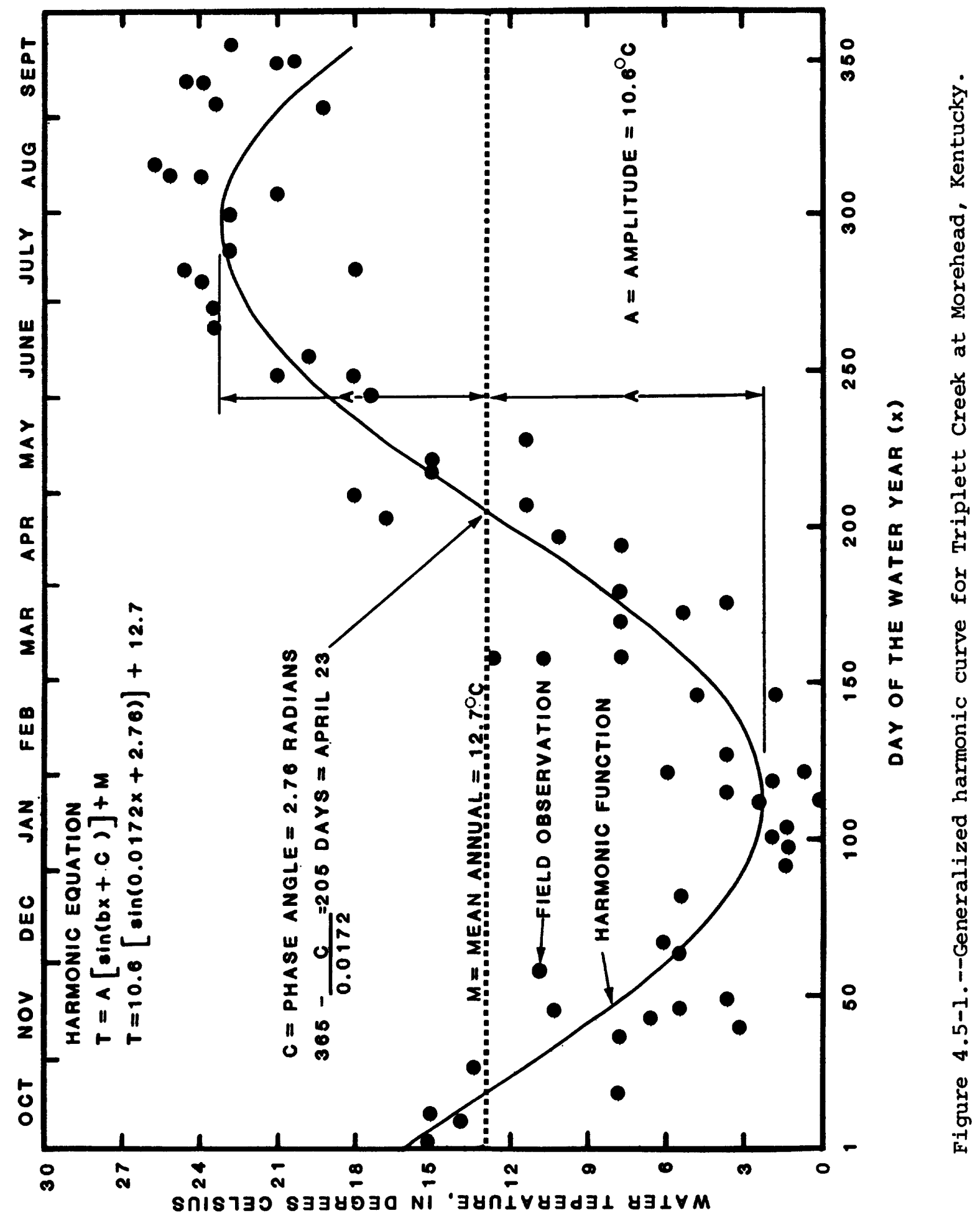


Table 4.5-1 Harmonic coefficients for the seven study sites

\begin{tabular}{|c|c|c|c|c|c|c|}
\hline & $\begin{array}{c}\text { Sample } \\
\text { size } \\
\text { (days) }\end{array}$ & $\begin{array}{c}\text { Harmonic } \\
\text { mean } \\
M \\
(\text { deg. C) }\end{array}$ & $\begin{array}{c}\text { Ampli tude } \\
\text { A } \\
\text { (deg. C) }\end{array}$ & $\begin{array}{c}\text { Phase } \\
\text { angle } \\
\text { C } \\
\text { (radians) }\end{array}$ & $\begin{array}{l}\text { Variation } \\
\text { explained } \\
\text { (percent) }\end{array}$ & $\begin{array}{l}\text { Standard } \\
\text { error of } \\
\text { estimate } \\
\text { (deg. C) }\end{array}$ \\
\hline $\begin{array}{l}\text { Little Cana } \\
\text { Creek }\end{array}$ & 183 & 13.49 & 12.43 & 2.79 & 88 & 2.56 \\
\hline Bankston Fork & 365 & 14.93 & 9.71 & 2.80 & 94 & 1.75 \\
\hline Turkey Creek & 292 & 11.85 & 14.66 & 2.75 & 91 & 2.97 \\
\hline $\begin{array}{l}\text { West Branch } \\
\text { Big Creek }\end{array}$ & 345 & 12.72 & 13.53 & 2.81 & 96 & 1.87 \\
\hline Slug Run & 715 & 12.39 & 12.68 & 2.80 & 93 & 2.51 \\
\hline Doza Creek & 254 & 14.53 & 13.90 & 2.84 & 96 & 1.96 \\
\hline $\begin{array}{r}\text { South Branch } \\
\text { Doza Creek }\end{array}$ & 221 & 13.18 & 13.89 & 2.84 & 93 & 2.66 \\
\hline
\end{tabular}




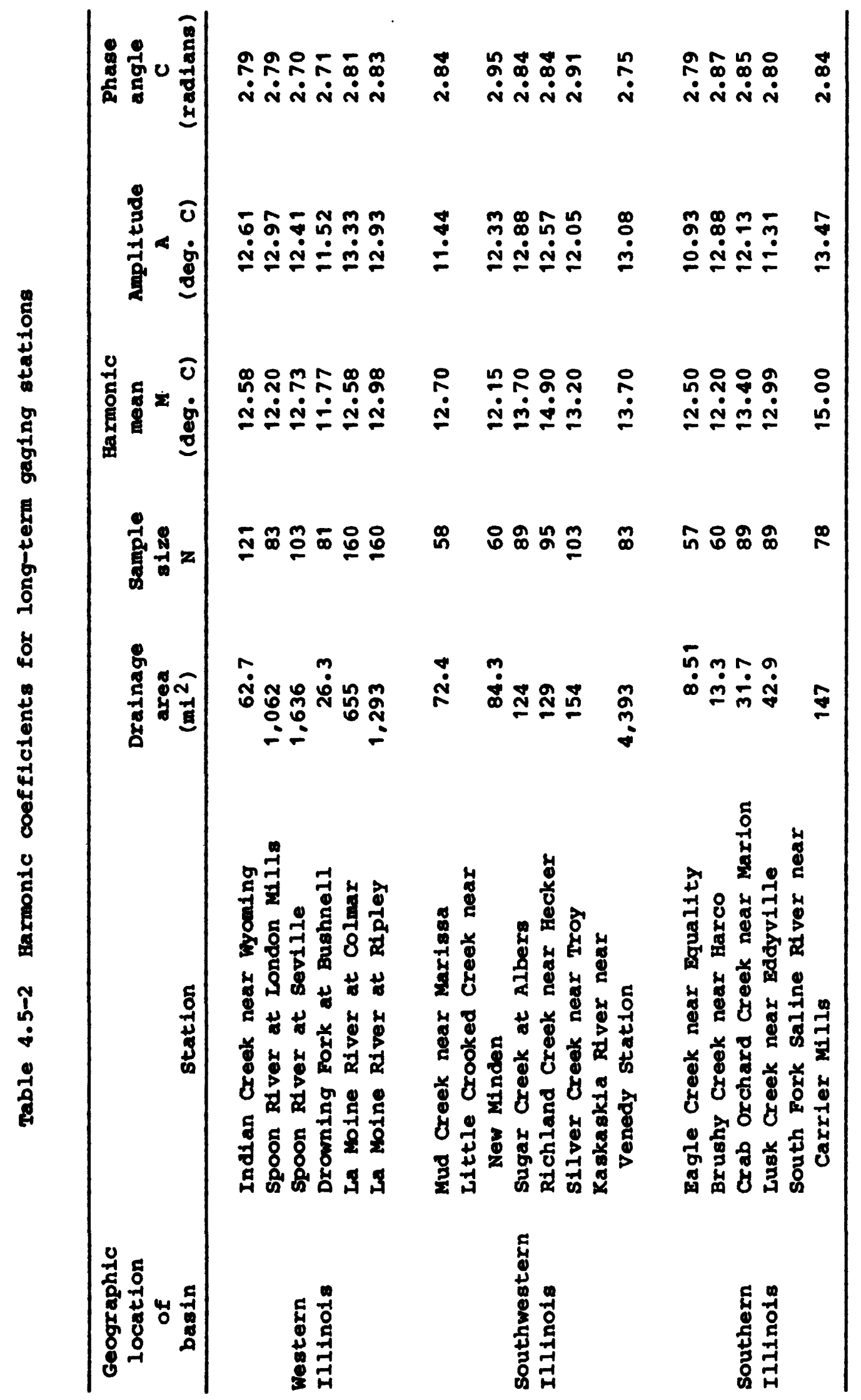




\title{
4.0 Quality of Surface Water \\ 4.6 Suspended Sediment
}

\section{SURFACE-MINED BASINS MAY YIELD LESS SUSPENDED SEDIMENT THAN UNMINED BASINS}

\begin{abstract}
Suspended-sediment loads from mined basins were lower than yields from unmined basins. However, the unmined basins are primarily farmland, and the mined basins have had no active surface mining for at least 5 years.
\end{abstract}

Suspended-sediment samples were collected monthly and during high runoff at six study sites. In addition, daily suspended-sediment samples have been collected at slug Run since 1975.

For this study, the suspended-sediment samplers used could not sample within 0.3 foot of the stream bottom. Therefore, the sediment below this level, which constitutes the bedload, was not measured. Only suspendedsediment data are given in this report, and no attempt was made to estimate bedload transport.

Sediment yields at the six study sites were determined by the transportduration technique. This technique makes use of (1) sediment-transport curves that define relations between instantaneous water and sediment discharges, and (2) streamflow-duration curves that define the percentage of time that any flow value was equaled or exceeded. The sample calculation for Iittle cana Creek, shown in table 4.6-1, is based on figures 4.6-1 and 4.6-2.

The above procedure was used to calculate annual sediment yields for the six study sites. These and the 5-year average yield for slug Run are:

\begin{tabular}{|c|c|c|c|c|}
\hline $\begin{array}{l}\text { Southern } \\
\text { Illinois- } \\
\text { basins }\end{array}$ & $\begin{array}{l}\text { Little Cana Creek (unmined) } \\
\text { Bankston Fork ( } 99 \text { percent mined) }\end{array}$ & $=$ & 125 & tons/mi 2 \\
\hline \multirow{3}{*}{$\begin{array}{l}\text { Western } \\
\text { Illinois- } \\
\text { basins }\end{array}$} & Turkey Creek (unmined) & $=$ & 233 & tons $/ \mathrm{mi}^{2}$ \\
\hline & $\begin{array}{l}\text { West Branch Big Creek } \\
\text { (29 percent mined) }\end{array}$ & $=$ & 57 & tons $/ \mathrm{mi}^{2}$ \\
\hline & Slug Run (90 percent mined) & $=$ & 125 & tons $/ \mathrm{mi}^{2}$ \\
\hline $\begin{array}{l}\text { Southwestern } \\
\text { Illinois } \\
\text { basins }\end{array}$ & $\begin{array}{l}\text { South Branch Doza Creek (unmined) } \\
\text { Doza Creek ( } 50 \text { percent mined) }\end{array}$ & 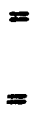 & 425 & tons/mi 2 \\
\hline
\end{tabular}

Probable reasons why mined basins produced lower sediment yields than unmined basins are (1) the higher infiltration capacity of mine spoil, (2) the effects of reestablished continual vegetative cover in mined areas that reduces overland flow and sediment loads, and (3) the fact that much of the unmined area was farmland, which when tilled can produce very high sediment yields. 


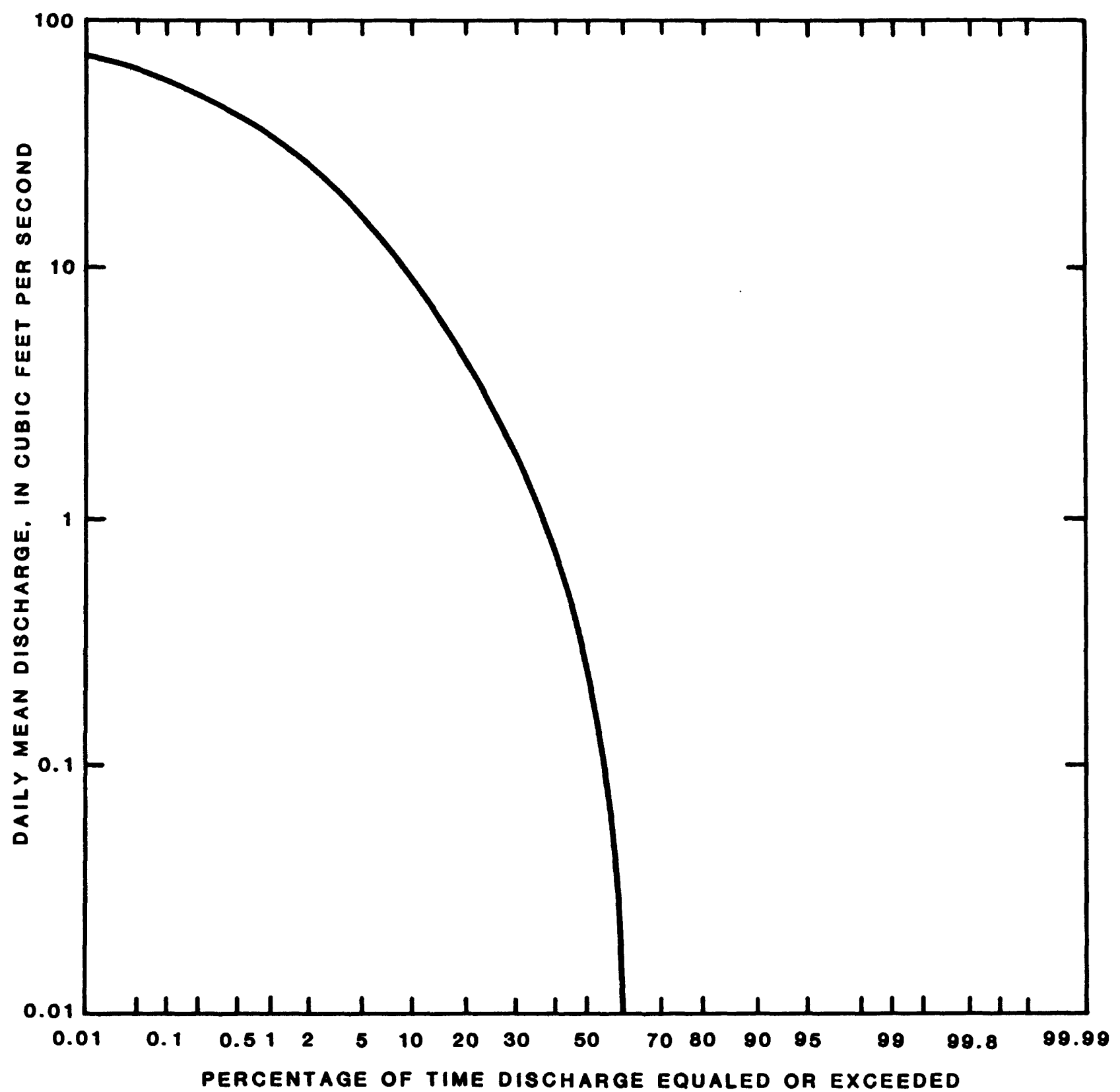

Figure 4.6-1.--Duration curve of daily mean discharge of Little Cana Creek.

56 


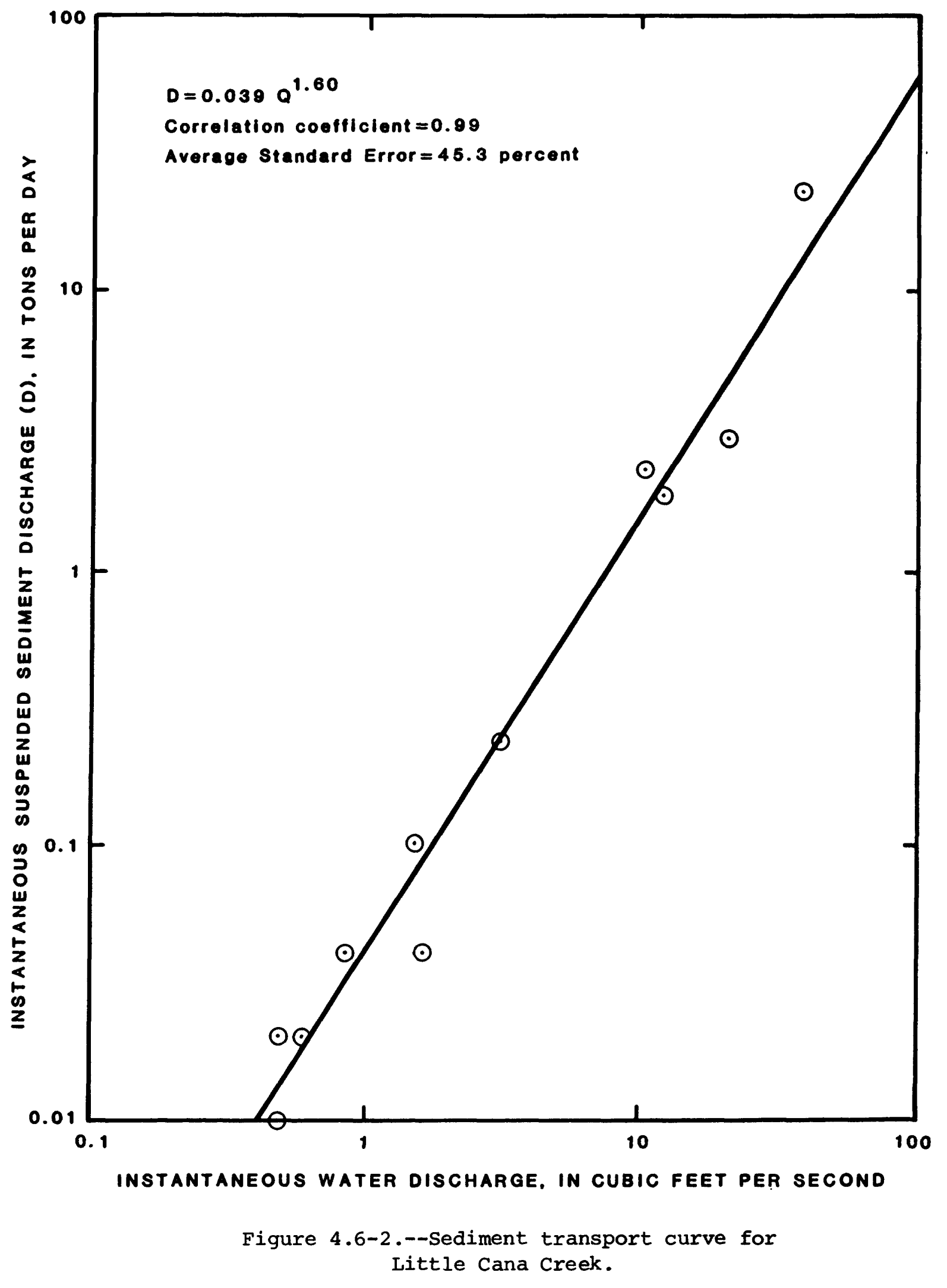


Table 4.6-1 Computations of mean annual suspended-sediment yield of Iittle Cana Creek near Creal springs

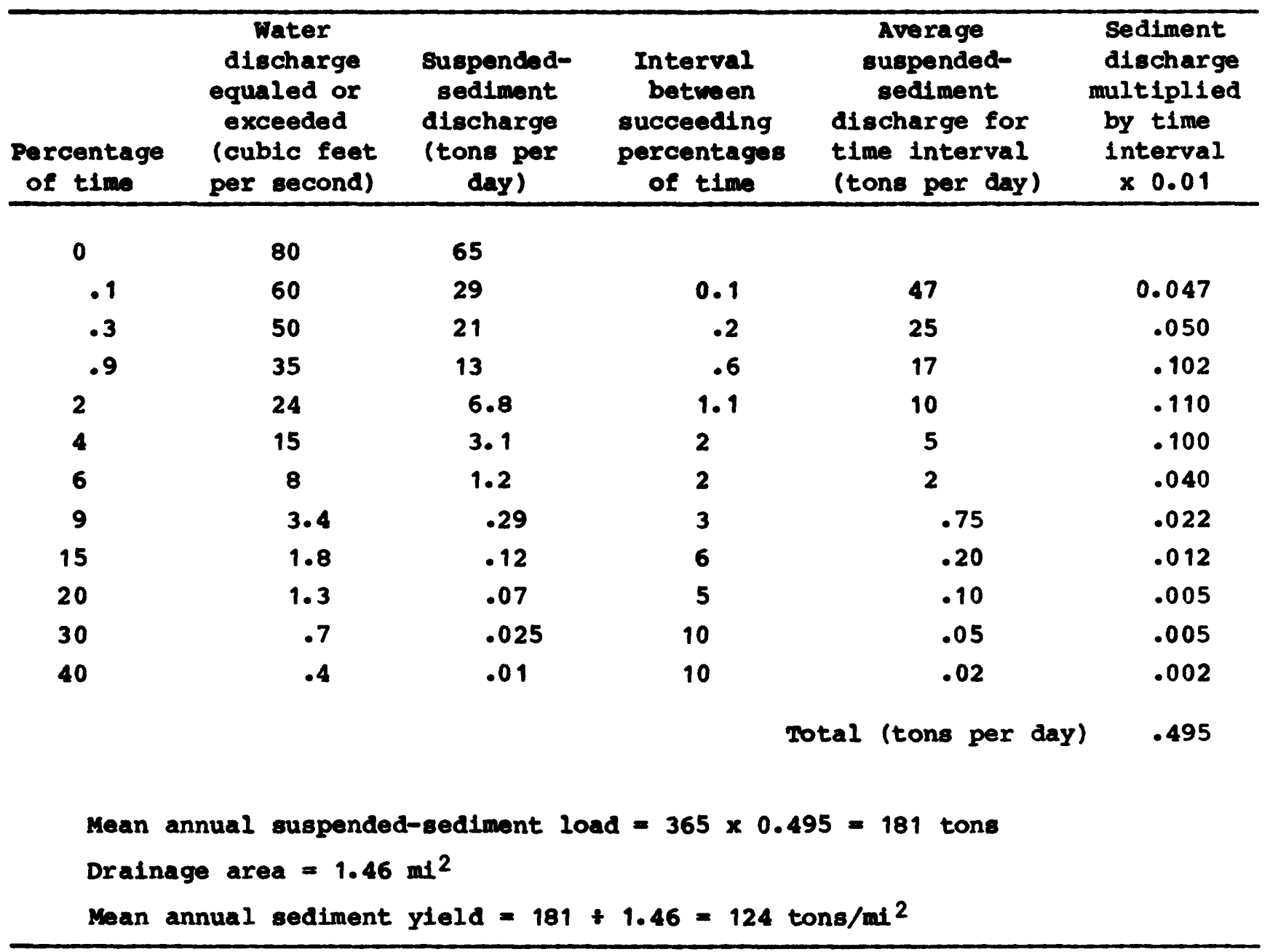




\title{
4.0 Quality of Surface Water \\ 4.7 Aluminum
}

\section{ALUMINUM IS PRESENT PREDOMINANTLY IN SUSPENDED PHASE}

\begin{abstract}
There is a direct relationship between concentrations of suspended aluminum and suspended sediment. Unmined areas contribute more aluminum than mined areas where in-place neutralization of mine-produced acid occurs.
\end{abstract}

Aluminum rarely is present in natural water in concentrations greater than a few tenths of a milligram per liter. Hem (1970) notes that, where the concentration of aluminum is high, the water generally has a low pH. Hem also reported that where aluminum concentration is $1 \mathrm{mg} / \mathrm{L}$ or more in pH-neutral water and complexing ions are present, the aluminum probably takes the form of aluminum hydroxide or an aluminosilicate. Clays are the most common of all the aluminum-bearing minerals in sediment.

In six study areas, aluminum concentrations in the dissolved phase were low; no data were available for slug Run. Suspended-aluminum concentrations were high during high flow and seemingly are associated with suspended sediment.

Figure 4.7-1 shows the relation between the suspended-aluminum concentrations and suspended-sediment concentrations for little Cana Creek. These constituents are also highly correlated at the other five study sites. The respective equations and correlation coefficients (cc) for each station are:

Little Cana Creek (unmined)

$$
\mathrm{SA}=16.3+19.8(\mathrm{SS}) \quad \mathrm{CC}=0.99
$$

Bankston Fork (99 percent mined)

$$
\mathrm{SA}=4.9+0.47 \text { (SS) } \quad \mathrm{CC}=0.80
$$

Turkey Creek (unmined)

$$
\begin{aligned}
S A & =-436+9.2 \\
S S & >48
\end{aligned}
$$

West Branch Big Creek (29 percent mined)

$$
\mathrm{SA}=129+7.8 \text { (SS) } \quad \mathrm{CC}=0.71
$$

South Branch Doza Creek (unmined)

$$
S A=-444+16.9(S S) \quad C C=0.97
$$

Doza Creek (50 percent mined)

$$
\begin{aligned}
& S A=-348+19.0 \text { (SS) } \quad C C=0.90 \\
& \text { SS }>18
\end{aligned}
$$


where $S A=$ concentration of suspended aluminum, in micrograms per liter $(\mu \mathrm{g} / \mathrm{L})$;

SS = suspended-sediment concentration, in milligrams per liter (mg/L);

$c c=$ correlation coefficient.

slopes from the regression equations give the micrograms of aluminum assoclated with each milligram of suspended sediment. Using the annual load of suspended sediment (from section 4.6) and the above relations, the annual yield of aluminum for the six sites can be estimated. The estimated annual yields are:

Little Cana Creek (unmined) $=2.5$ tons $/ \mathrm{mi}^{2}$

Bankston Fork (99 percent mined) $=0.04$ tons $/ \mathrm{mi}^{2}$

Turkey Creek (unmined) $=2.1$ tons $/ \mathrm{mi}^{2}$

West Branch Big Creek (29 percent mined) $=0.44$ tons $/ \mathrm{mi}^{2}$

South Branch Doza Creek (unmined) $=7.2 \mathrm{tons} / \mathrm{mi}^{2}$

Doza Creek (50 percent mined) $=2.9$ tons $/ \mathrm{mi}^{2}$

These results indicate that more aluminum is transported from the unmined basins than the mined basins. However, the three mined basins have nearneutral pH ranges (see table 4.11-1), and, thus, little aluminum is in solution. An example of the potential abundance of aluminum at low pH is provided by the South Fork Saline River. During the 1979 water year, pH ranged from 2.9 to 6.2 and dissolved aluminum values ranged from $<100$ to $34,500 \mu \mathrm{g} / \mathrm{L}$. A relation was developed between dissolved aluminum and dissolved solids (fig. 4.7-2). Based on this relation, the annual yield of aluminum transported from this basin was 87 tons $/ \mathrm{mi}^{2}$, which is considerably higher than yields from the six study basins. 


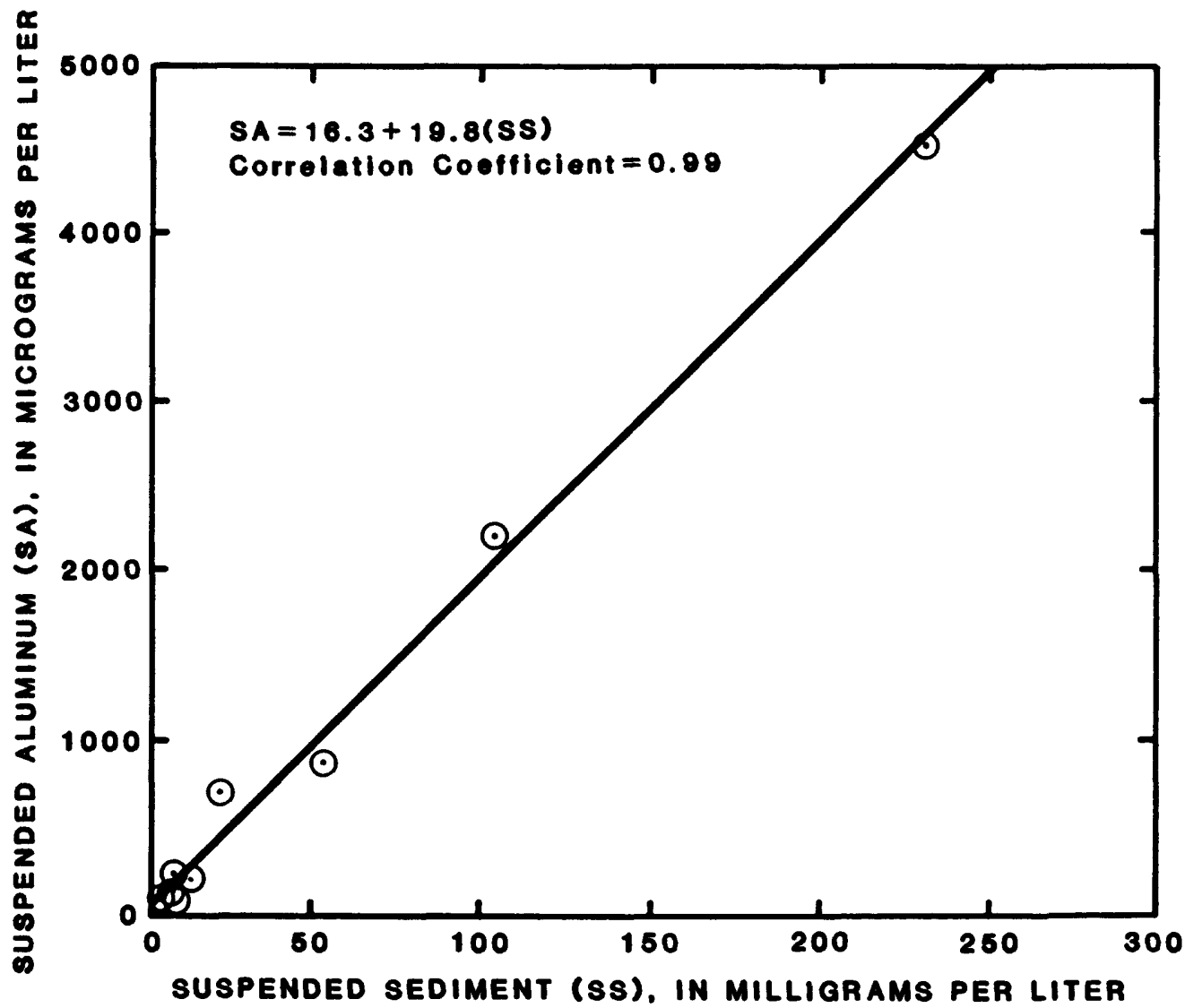

Figure 4.7-1.--Relation between suspended aluminum and suspended sediment for Little Cana Creek.

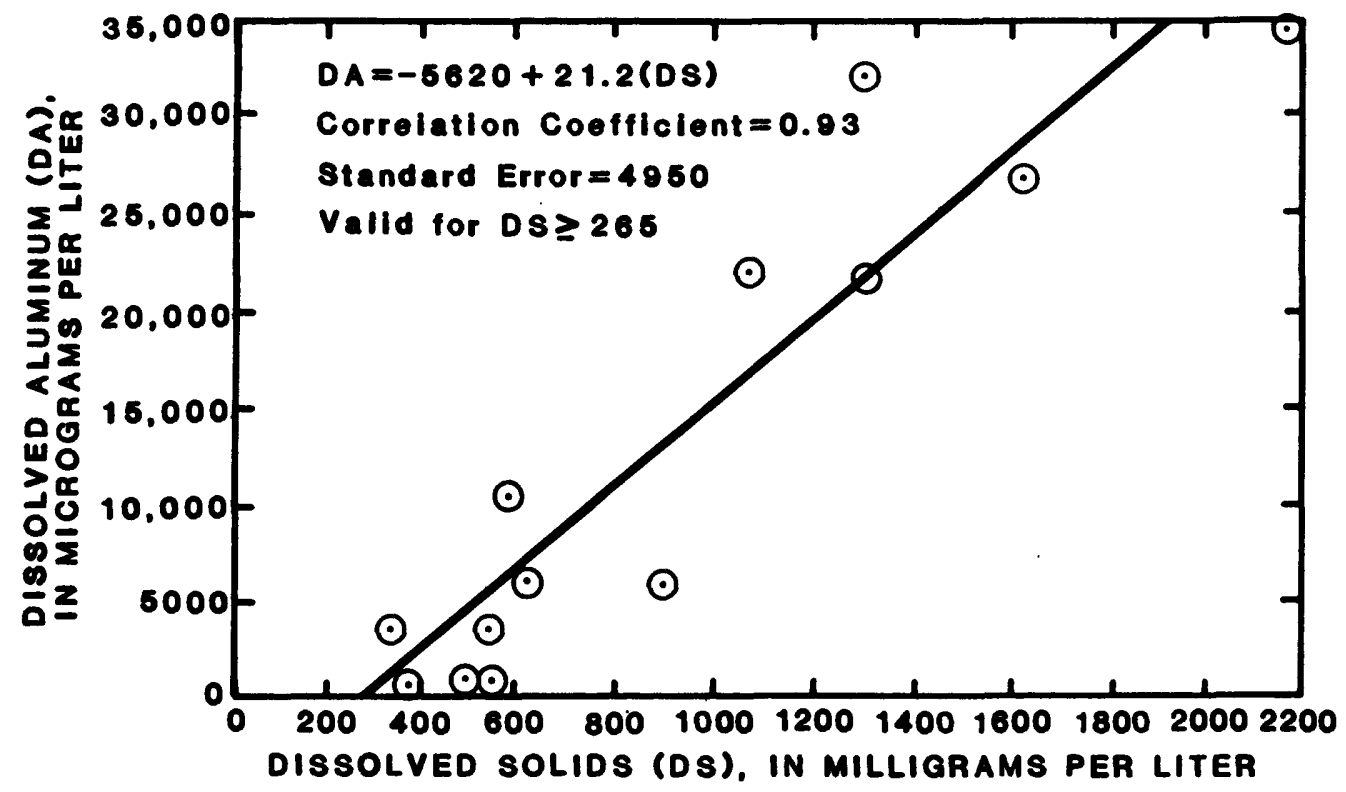

Figure 4.7-2.--Relation between dissolved aluminum and dissolved solids for South Fork Saline River. 


\title{
4.0 Quality of Surface Water 4.8 Iron
}

\section{IRON IS PRESENT PREDOMINANTLY IN SUSPENDED PHASE}

\author{
There is a relation between concentrations of suspended iron \\ and suspended sediment. Unmined areas yield more iron \\ than mined areas where in-place neutralization of \\ mine-produced acid occurs.
}

Iron is an abundant and widespread constituent of rocks and soils. It is most common in sediments in the ferrous form as polysulfides (pyrite or marcasite), siderite, and magnetite. Hem (1970, p. 114) has stated that at near-neutral pH, water will not contain significant concentrations of dissolved iron. If the concentration of iron is high, it probably is present as particles of ferric hydroxide.

For six watersheds, near-neutral pH ranges and low dissolved-iron concentrations were observed; no dissolved-iron data were available for slug Run. However, suspended-iron concentrations were high during high flows. Because high suspended-sediment concentrations were also observed during high flows, the iron is probably present as particles of iron minerals or sorbed on grains of suspended sediment.

Figure 4.8-1 shows the relationship between suspended iron and suspended sediment for Iittle Cana Creek. The relation is similar for the five other sites. Regression equations and correlation coefficients (cc) for the other five sites are:

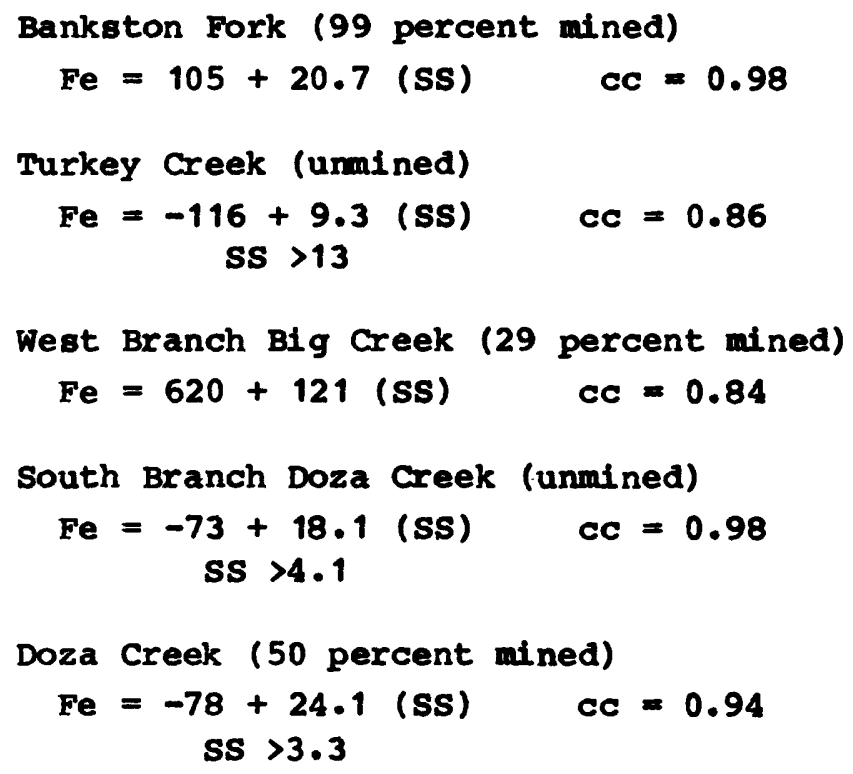


where $\mathrm{Fe}=$ concentration of suspended iron, in micrograms per liter $(\mu \mathrm{g} / \mathrm{L})$;

SS = concentration of suspended sediment, in milligrams per liter (mg/L),

$c c=$ correlation coefficient.

As was the case with aluminum (section 4.7), the slope of the regression line (coefficient for SS) gives the micrograms of iron associated with each milligram of suspended sediment. With knowledge of the annual sediment loads for the six sites and the above relation, the annual yield of iron can be estimated. The estimated annual yields are:

Little Cana Creek (unmined) $=2.8$ tons $/ \mathrm{mi}^{2}$

Bankston Fork $(99$ percent mined $)=1.7$ tons $/ \mathrm{mi}^{2}$

Turkey Creek (unmined) $=2.1$ tons $/ \mathrm{mi}^{2}$

West Branch Big Creek (29 percent mined) $=1.2$ tons $/ \mathrm{mi}^{2}$

South Branch Doza Creek (unmined) $=7.6$ tons $/ \mathrm{mi}^{2}$

Doza Creek (50 percent mined) $=3.6$ tons $/ \mathrm{mi}^{2}$

The calculated yields of suspended iron are higher from the unmined basins than from the mined basins. As with aluminum, most of the iron occurs in the suspended phase. 


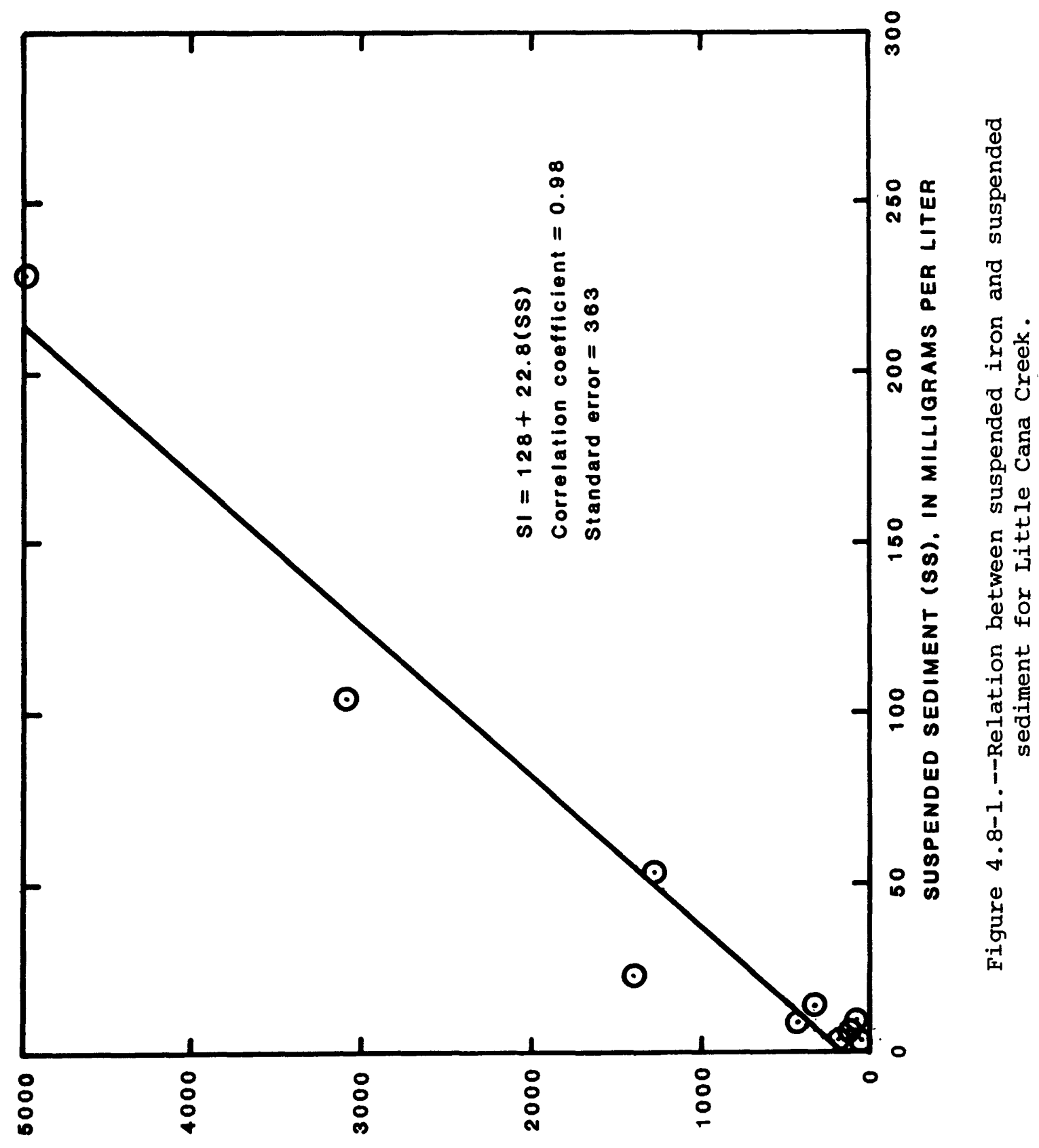

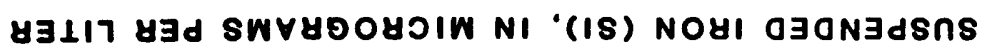




\subsection{Quality of Surface Water \\ 4.9 Manganese and zinc}

MANGANESE AND ZINC CONCENTRATIONS ARE GENERALLY LOW

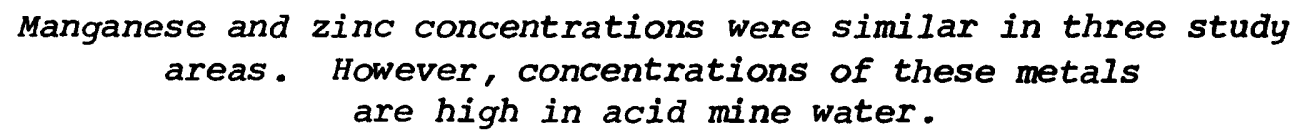

Mean manganese concentrations ranged from 33 to $1,100 \mu \mathrm{g} / \mathrm{L}$, and mean $z i n c$ concentrations ranged from 24.5 to $37.6 \mu \mathrm{g} / \mathrm{L}$ at the six study sites. Hem (1970, p. 130, 203) has noted that, commonly, at near-neutral pH levels, manganese concentrations will range from 100 to $1,000 \mu \mathrm{g} / \mathrm{L}$ and that $\mathrm{zinc}$ concentrations will remain less than $500 \mu \mathrm{g} / \mathrm{L}$. Thus, for all study areas, the concentrations of these two elements were within commonly observed ranges.

Under acidic conditions, metals such as manganese and zinc are more soluble. Figures 4.9-1 and 4.9-2 show the relation between concentrations of dissolved zinc, dissolved manganese, and dissolved solids for the acidic conditions in the South Fork Saline River. Concentrations are high, and the average annual yields are 1.9 tons $/ \mathrm{mi}^{2}$ of zinc and 34 tons/ $\mathrm{mi}^{2}$ of manganese. 


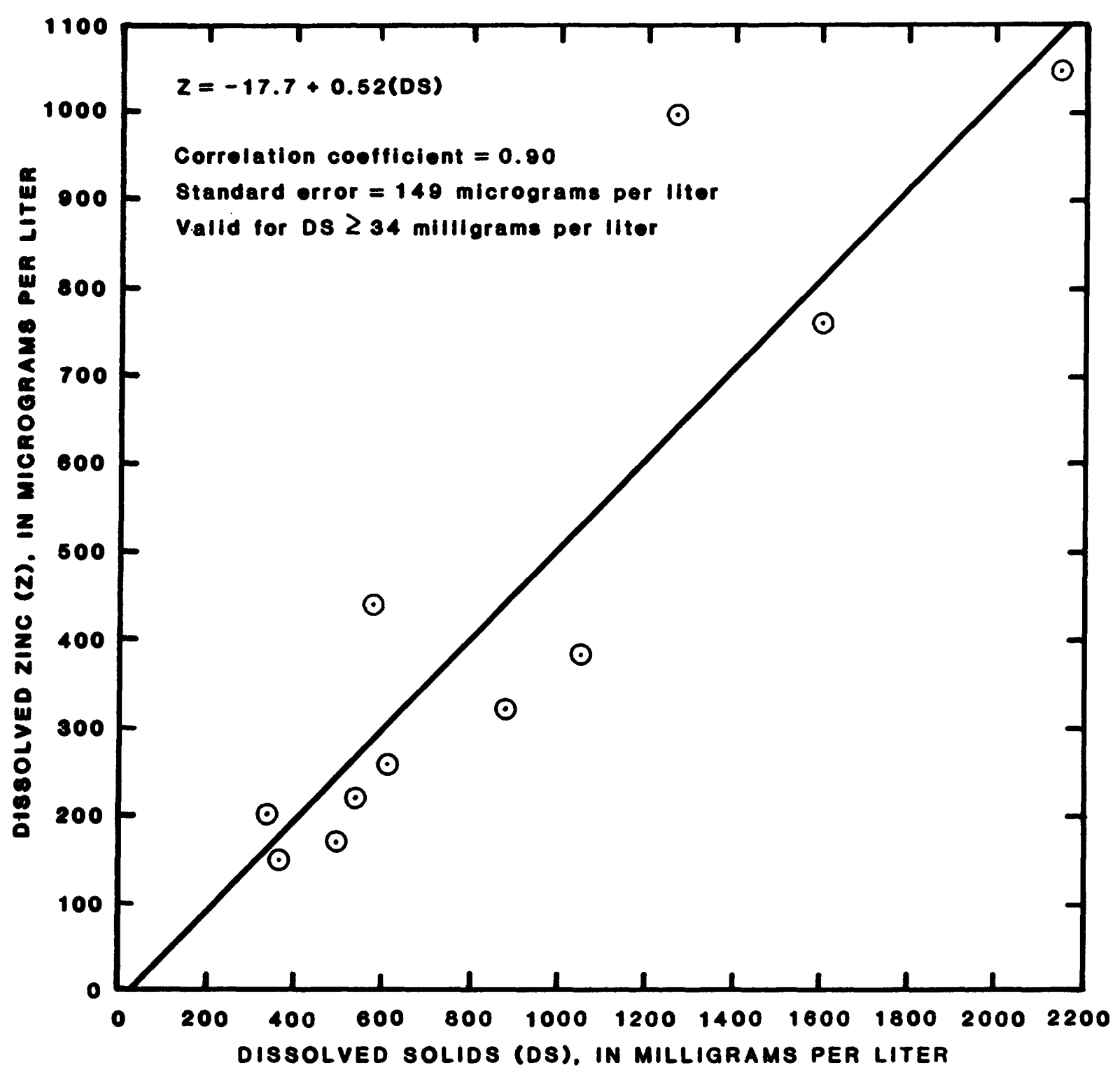

Figure 4.9-1.--Relation between dissolved zinc and dissolved solids for South Fork Saline River. 


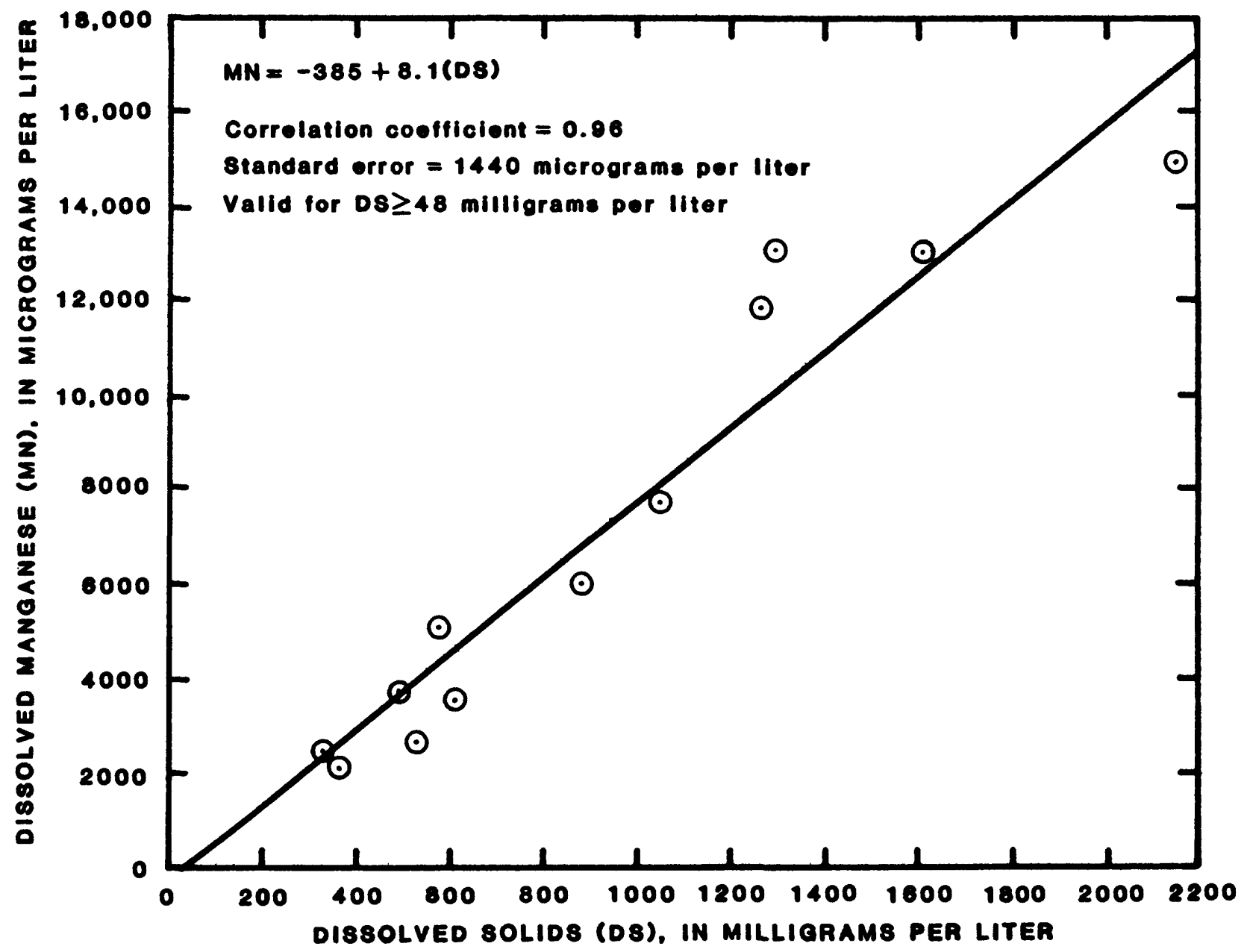

Figure 4.9-2.--Relation between dissolved manganese and dissolved solids for South Fork Saline River. 
4.0 Quality of Surface Water

4.10 Trace Elements

TRACE METAL CONCENTRATIONS ARE SIMILAR IN MINED

AND UNMINED BASINS

An analysis of nine trace metals showed no major differences

in concentration between unmined and mined basins,

where waters are in near-neutral pH range.

Tables 4.10-1 to 4.10-3 show the results of analyses for trace elements in samples collected at six of the study sites. For each metal the number of samples, range, mean, and standard deviation are given.

Concentrations of most trace elements are correspondingly similar in mined and unmined areas. Boron concentrations, however, seem to be slightly higher in the mined basins.

Iinear regression techniques were used for data from six of the watersheds to check for any relations anong the trace metals, dissolved solids, suspended sediment, or discharge. As noted in sections 4.6, 4.7, and 4.8, high levels of correlation existed between suspended sediment and discharge, suspended aluminum and suspended sediment, and suspended iron and suspended sediment. In sections $4.7,4.8$, and 4.9 , it was shown that, under acidic conditions, dissolved aluminum, iron, manganese, and zinc correlate well with dissolved solids. The remaining metals showed little correlation with dissolved solids, discharge, and suspended sediment. 


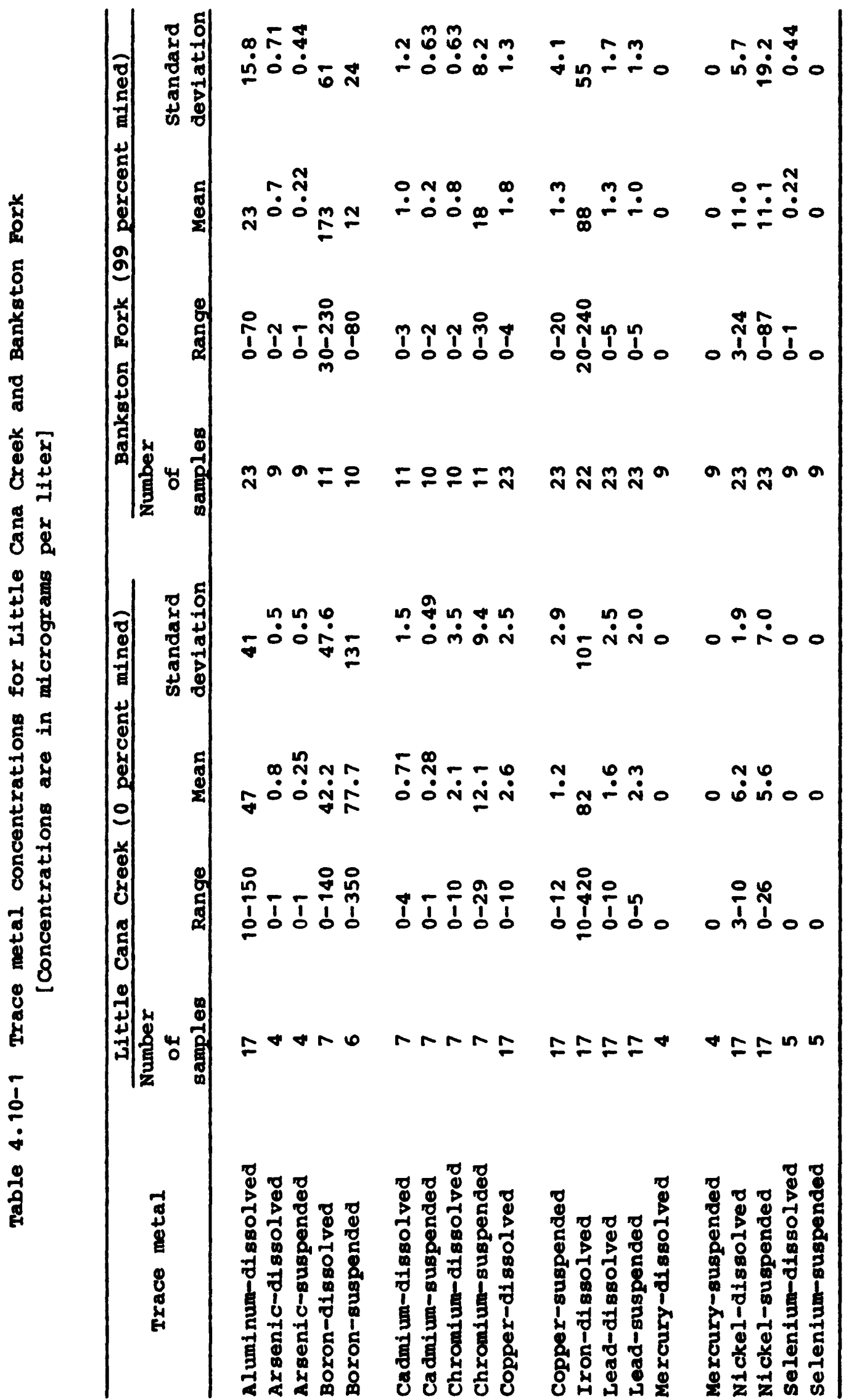




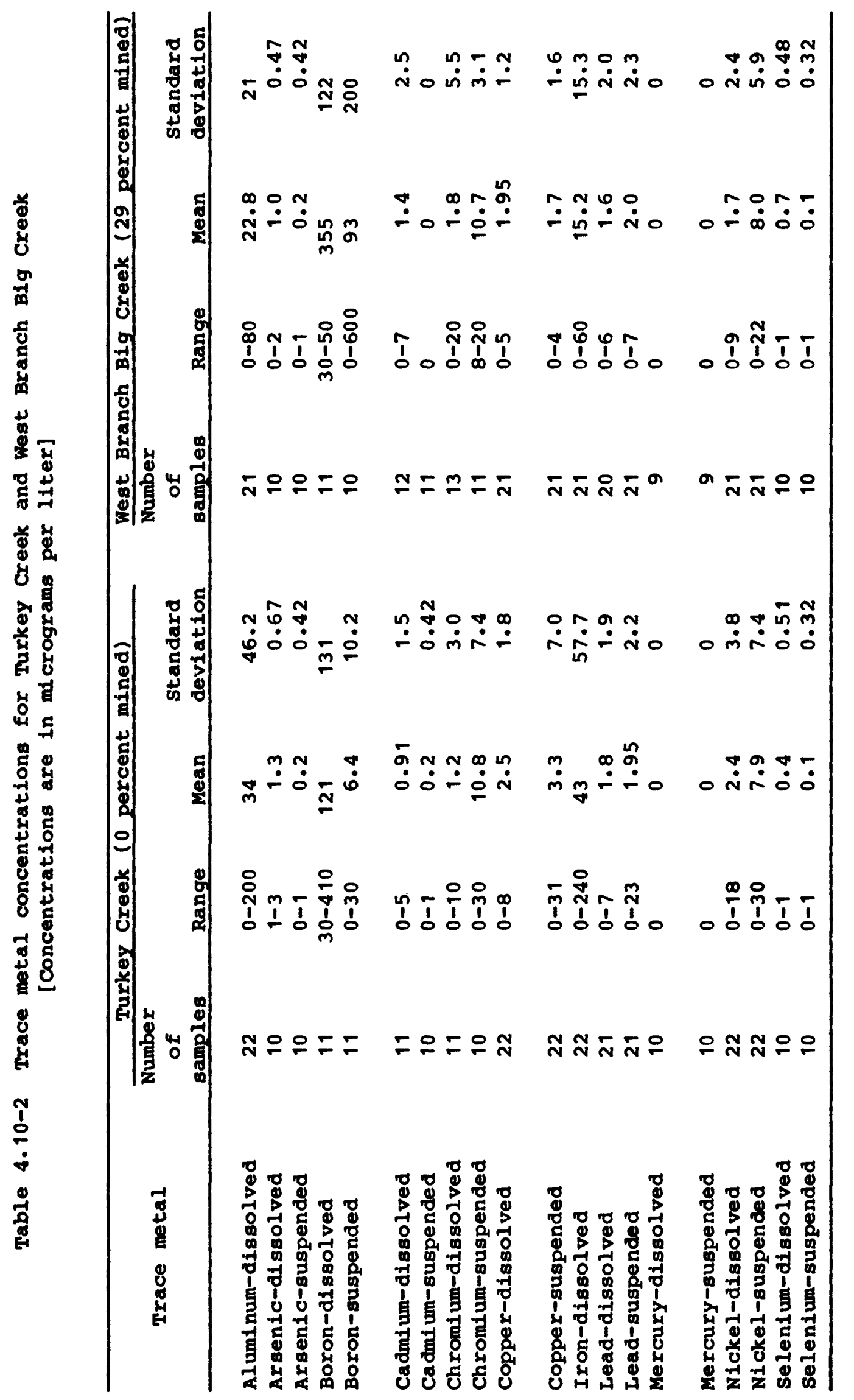




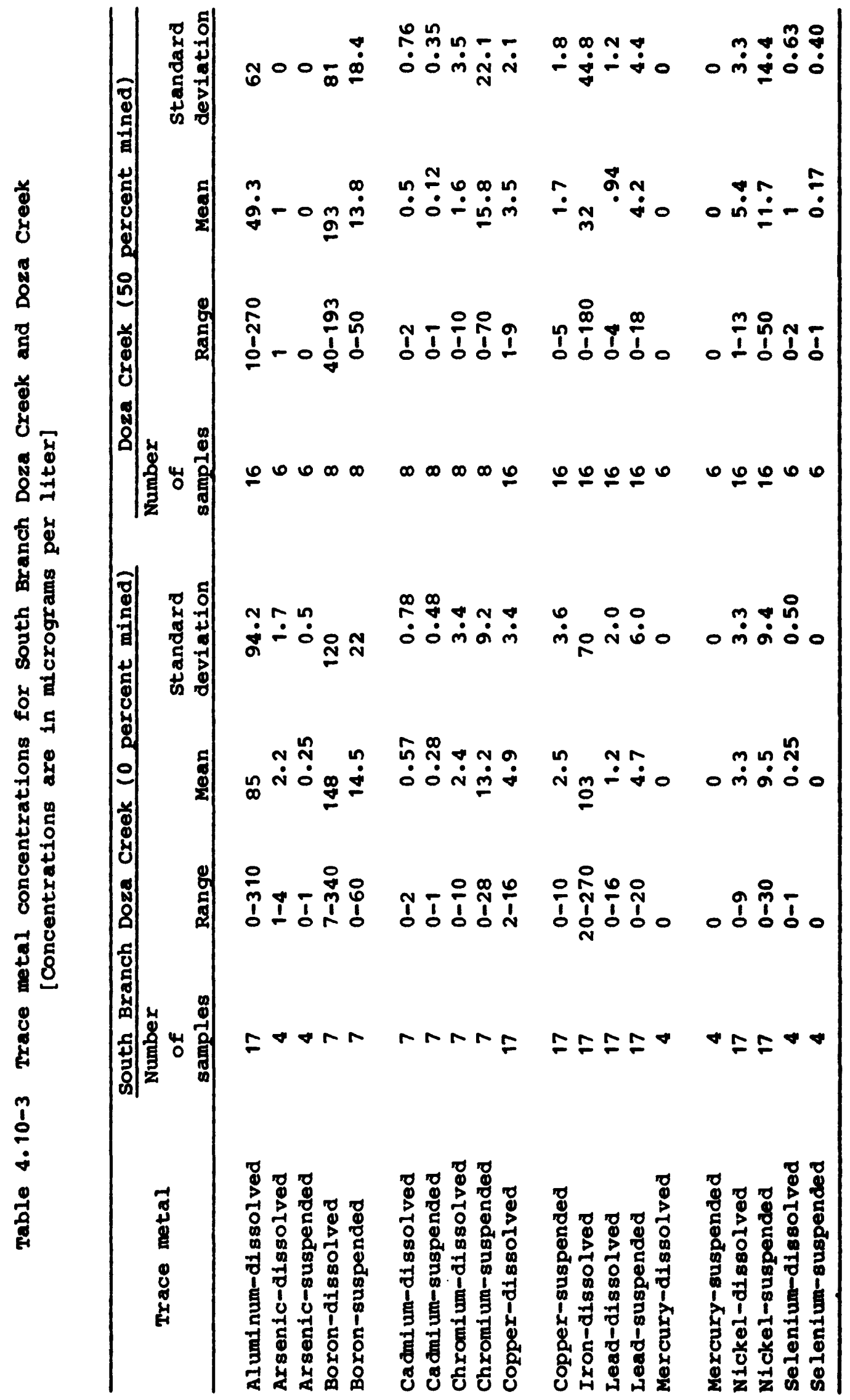


4.0 Quality of Surface Water

4.11 Common Chemical Constituents and Properties

CONCENTRATIONS OF MANY COMMON CHEMICAL CONSTITUENTS AND PROPERTIES ARE SIMILAR IN MINED AND UNMINED BASINS
An analysis of common chemical constituents and properties shows concentrations to be similar in mined and unmined basins. These concentrations seem to vary more according to location than to mining conditions.

Tables 4.11-1, 4.11-2, and 4.11-3 show that many chemical elements have similar concentrations for both mined and unmined basins. Included in this category are dissolved organic carbon, total organic carbon, nitrogen, dissolved oxygen, phosphorus, and silica. Properties such as pH and sodium adsorption ratio were also similar for both mined and unmined basins.

Sodium concentrations were consistently higher in streams draining the surface-mined basins. However, little correlation was found between this element and the percentage of the drainage basin that was surface mined.

Noncarbonate hardness is that portion of hardness in excess of that equivalent to carbonate plus bicarbonate. This type of hardness was greater in streams draining surface-mined basins.

The concentrations of other common constituents or properties vary more as a result of location of the study basin than as a result of mining. In the Saline River basin, alkalinity, bicarbonate, and total hardness are higher in streams draining mined basins. In the lower Kaskaskia River basin, water from South Branch Doza Creek (unmined site) has higher alkalinity and bicarbonate values than Doza Creek (mined site). However, Doza Creek has higher total hardness values. In western Illinois, Turkey Creek (unmined) has higher alkalinity, bicarbonate, and total hardness values than west Branch Big Creek (mined). Slug Run (90 percent mined) has higher total hardness values than Turkey Creek but similar values for alkalinity and bicarbonate. Chloride values were higher for the study basins in western and southwestern Illinois for streams draining mined areas but lower for streams draining surface-mined areas in the Saline River basin. Potassium values were higher in southern and western Illinols basins but lower in southwestern Illinols for streams draining mined basins. Magnesium values were higher in the mined basin in southern Illinols basins (Bankston Fork) but about the same for mined and unmined basins in southwestern and western Illinois. 


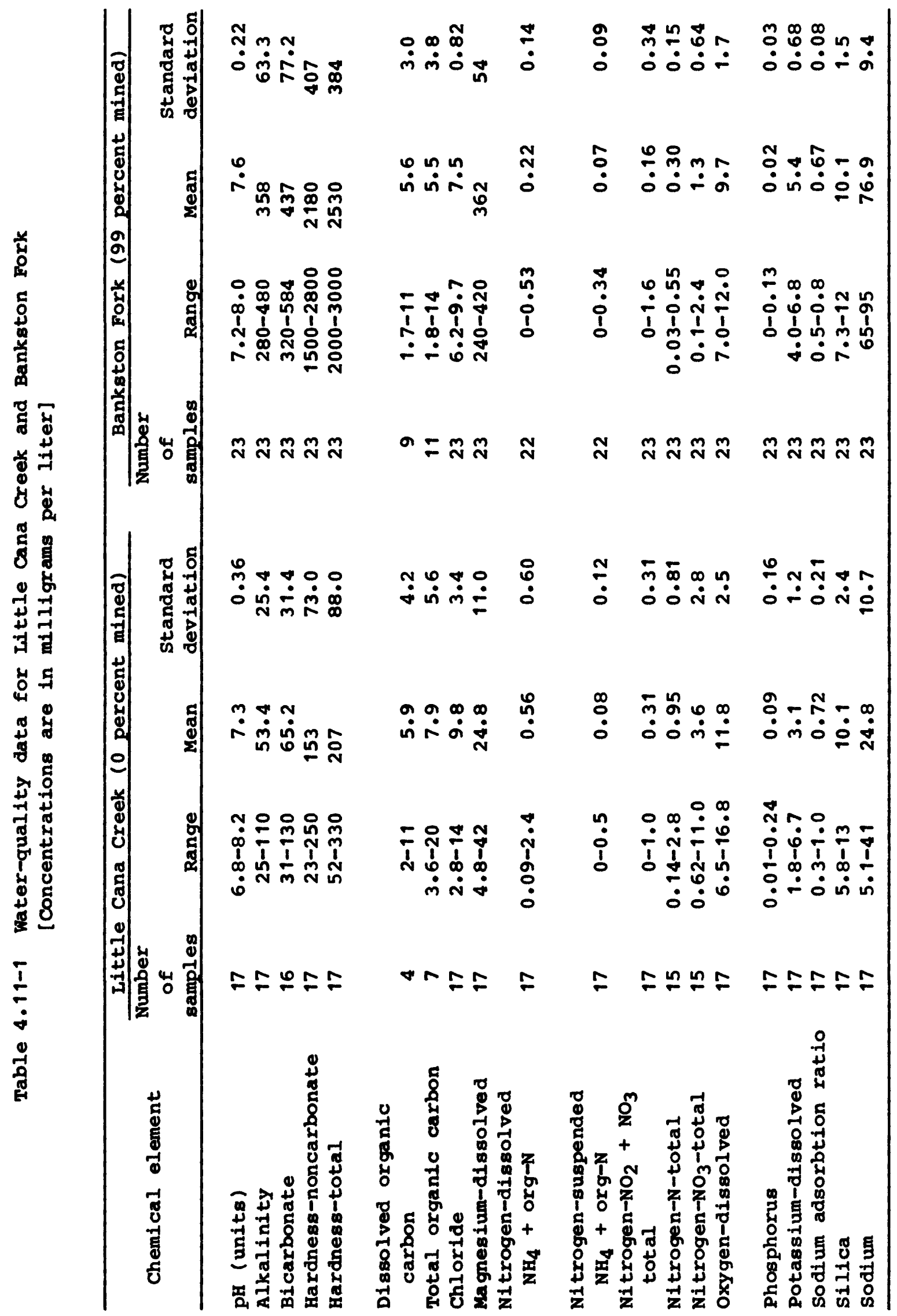




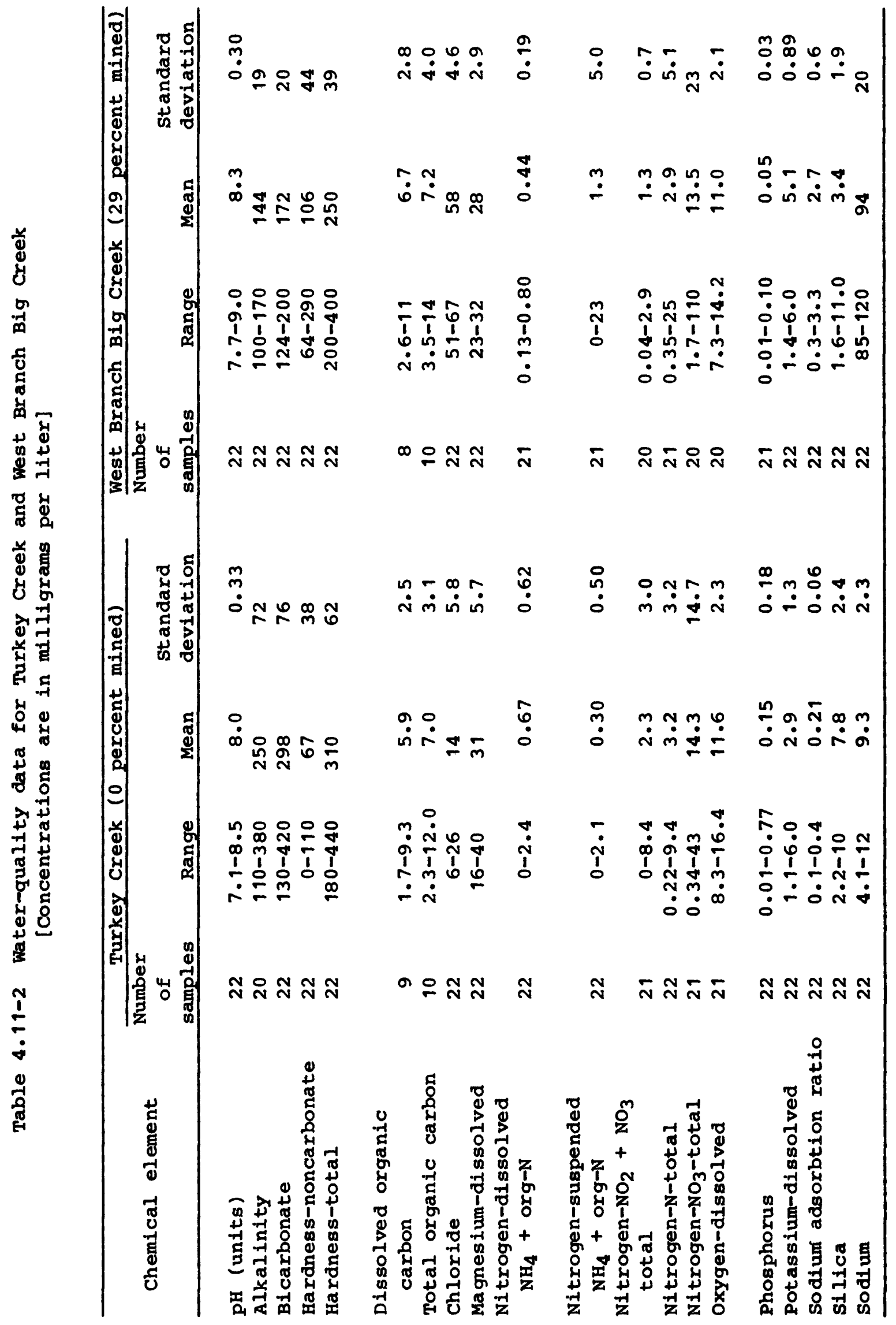




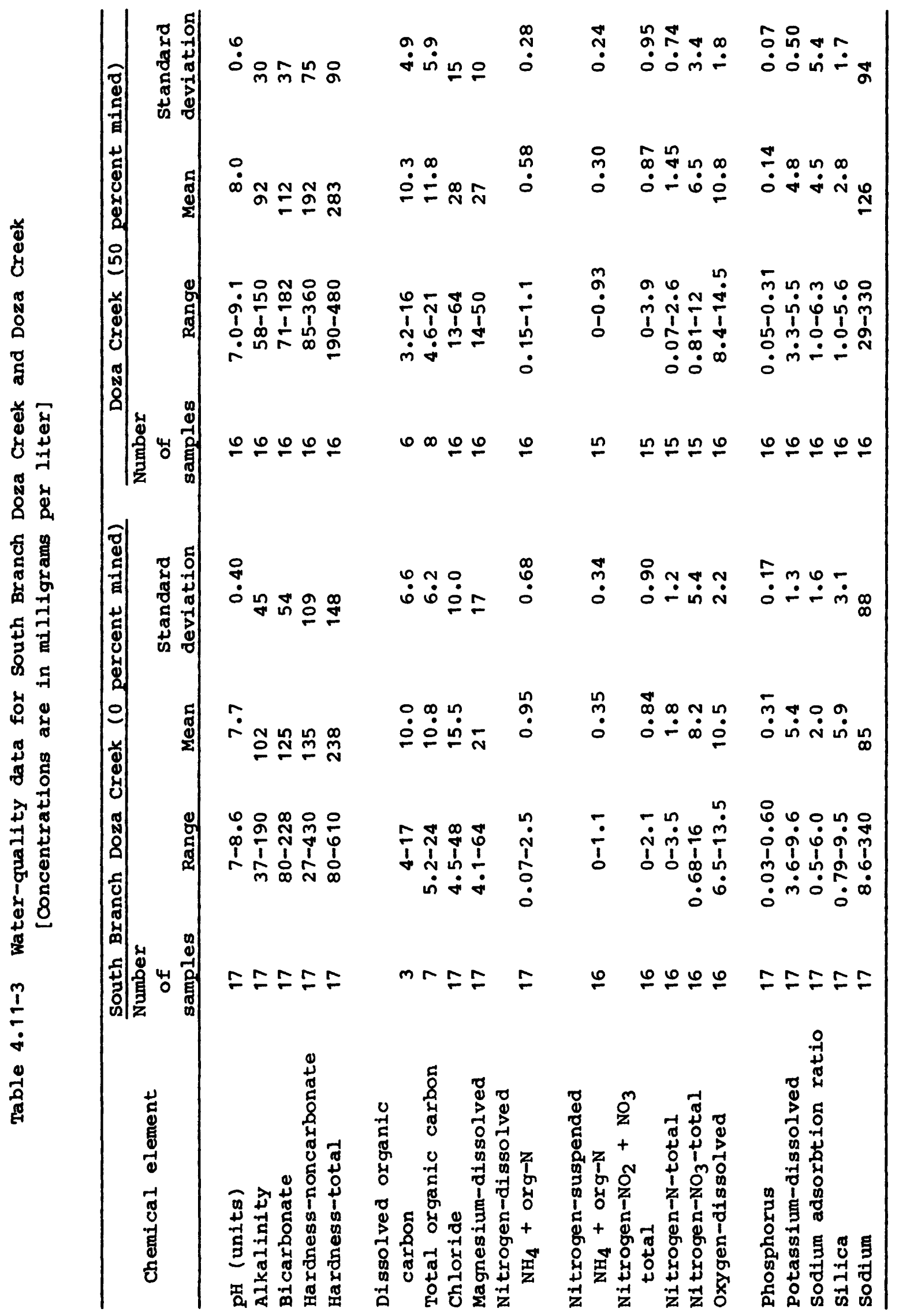




\subsection{Quality of Surface Water 4.12 Conclusions}

Surface mining in Illinois has exposed unweathered rocks, chemical weathering of which has resulted in increased concentrations and loads of dissolved chemical constituents in runoff.

Relations between dissolved solids, sulfate, and calcium were developed for the Saline-Big Muddy River basins in southern Illinois and the Spoon River basin in western Illinois. If the percentage of a basin that is surface mined is known, annual yields for these constituents in runoff can be estimated. Yields of dissolved solids, sulfate, and calcium associated with mining were greater in the saline-Big Muddy River basins than in basins studied in western Illinois. Increases in concentrations of dissolved constituents related to mining were least in the southwestern part of Illinois (the lower Kaskaskia River basin).

Harmonic analyses of daily water temperatures indicate that streams draining mined areas have higher harmonic means and lower amplitudes than streams draining unmined areas.

Suspended-sediment yields from each study area show that unmined areas have higher sediment yields than mined areas; however, the mined basins no longer have active surface mines and have been revegetated. Much of the unmined area is farmland.

Several trace metals were analyzed for possible correlations with suspended sediment and dissolved solids. Associations between iron, aluminum, and suspended sediment indicate that streams draining unmined basins have greater yields of aluminum and iron than the mined basins, possibly resulting from higher sediment yield from the unmined basins. However, this relationship does not hold for surface-mined basins with acidic (low pH) conditions such as the South Fork Saline River near Carrier Mills. 


\subsection{References}

Collings, M. R., 1969, Temperature analysis of a stream: U.S. Geological Survey Professional Paper 650-B, p. B174-B179.

Curtis, G. W., 1977, Frequency analysis of Illinois floods using observed and synthetic streamflow records: U.S. Geological Survey Water-Resources Investigations $77-104,32$ p.

Fitzgerald, K. K., Peters, C. A., and Zuehls, E. E., 1983, Hydrology of Area 29, Eastern Region, Interior Coal Province, Illinois: U.S. Geological Survey Water-Resources Investigations Open-File Report 82-858, $70 \mathrm{p}$.

Hem, J. D., 1970, Study and interpretation of the chemical characteristics of natural water: U.S. Geological Survey Water-Supply Paper 1473, 363 p.

Illinois Department of Mines and Minerals, 1980, 1979 Annual coal, oil and gas report: State of Illinois, Springfield, 321 p.

Lane, E. W., and Lei, Kai, 1950, Streamflow variability: merican Society of Civil Engineers Transactions, v. 115, p. 1084-1134.

Mitchell, w. D., 1957, Flow duration of Illinois streams: Illinois Department of Public Works and Buildings, Division of Waterways, 189 p.

Nawrot, J. R., Rlimstra, W. D., Jenkusky, S. M., and Hickmann, T. J., 1980, Illinois state reclamation plan for abandoned mined lands: Cooperative Wildlife Research Laboratory, Southern Illinois University at Carbondale, 254 p.

Rickert, D. A., Ulman, W. J., and Hampton, E. R., 1979, Synthetic fuels development--Earth science considerations: U.S. Geological survey Special Report, 45 p.

Searcy, J. K., 1959, Flow-duration curves: U.S. Geological Survey Water-Supply Paper 1542-A, 33 p.

Smith, W. H., and Stall, J. B., 1975, Coal and water resources for coal conversion in Illinois: Illinois State Geological survey and Illinois state Water Survey Cooperative Resources Report 4, 79 p. , 3 pls.

Steele, T. D., and Gilroy, E. J., 1972, Harmonic analysis of stream temperature data (abs.): EOS American Geophysical Union Transactions, v. 53, no. 4, p. 378 .

Toler, L. G., 1982, Some chemical characteristics of mine drainage in Illinois: U.S. Geological Survey Water-Supply Paper 2078, 47 p.

U.S. Geological Survey, 1981, Watex resources data for Illinois, Volume 1. Illinois except Illinois River basin, water year 1980: Urbana, Ill., U.S. Geological Survey Water-Data Report II-80-1, 708 p. 
--m 1981, Water resources data for Illinois, Volume 2. Illinois River besin, water year 1980: Urbana, Ill., U.S. Geological Survey Water-Data Report II-80-2, $468 \mathrm{p}$.

Ward, J. C., 1963, Annual varlation of stream temperature: American Society of Civil Engl neers, Journal of Sanitary Engineer Division, v. 89, no. SA6, p. 1-16.

Wllman, H. B., and others, 1975, Handbook of Illinois stratigraphy: Illinois state Geological survey Bulletin 95, Illinois Department of Registration and Education, 261 p.

zogorsk1, J. S., and Kiesler, J. L., 1976, water temperature of Rentucky: 0.s. Geological survey Open-File Report 76-86 (1-page map).

2uohls, E. F., and others, 1981a, Hydrology of Area 35, Eastern Region, Interior Coal Province, Illinois and Kentucky: U.S. Geological survey Water-Resources Investigations Open-File Report 81-403, 68 p.

-.-- 1981b, Aydrology of Area 25, Eastern Region, Interior Coal Province, Illinois: U.S. Geological survey Water-Resources Ingestigtions Open-File Report 81-636, 66 p. 